\title{
33. LATE OLIGOCENE TO RECENT BENTHIC FORAMINIFERS FROM DEEP SEA DRILLING PROJECT SITES 608 AND 610, NORTHEASTERN NORTH ATLANTIC ${ }^{1}$
}

\author{
E. Thomas, Scripps Institution of Oceanography²
}

\begin{abstract}
Deep-sea benthic foraminiferal faunas were studied from Sites 608 (depth $3534 \mathrm{~m}, 42^{\circ} 50^{\prime} \mathrm{N}, 23^{\circ} 05^{\prime} \mathrm{W}$ ) and 610 (depth $2427 \mathrm{~m}, 53^{\circ} 13^{\prime} \mathrm{N}, 18^{\circ} 53^{\prime} \mathrm{W}$ ). The sampling interval corresponded to 0.1 to $0.5 \mathrm{~m}$.y. at Site 608 and in the sections of Site 610 from which core recovery was continuous.

First and last appearances of benthic foraminiferal taxa are generally not coeval at the two sites, although the faunal patterns are similar and many species occur at both sites. Major periods of changes in the benthic faunas, as indicated by the numbers of first and last appearances and changes in relative abundances, occurred in the early Miocene (19.2$17 \mathrm{Ma}$ ), the middle Miocene (15.5-13.5 Ma), the late Miocene (7-5.5 Ma), and the Pliocene-Pleistocene (3.5-0.7 Ma). A period of minor changes in the middle to late Miocene (10-9 Ma) was recognized at Site 608 only.

These periods of faunal changes can be correlated with periods of paleoceanographic changes: there was a period of sluggish circulation in the northeastern North Atlantic from 19.2 to $17 \mathrm{Ma}$, and the deep waters of the oceans probably cooled between 15.5 and $13.5 \mathrm{Ma}$, as indicated by an increase in $\delta^{18} \mathrm{O}$ values in benthic foraminiferal tests. The period between 10 and $9 \mathrm{Ma}$ was probably characterized by relatively vigorous bottom-water circulation in the northeastern Atlantic, as indicated by the presence of a widespread reflector. The faunal change at 7 to $5.5 \mathrm{Ma}$ corresponds in time with a worldwide change in $\delta^{13} \mathrm{C}$ values, and with the Messinian closing of the Mediterranean. The last and largest faunal changes correspond in time with the onset and intensification of Northern Hemisphere glaciation.
\end{abstract}

\section{INTRODUCTION}

Deep-sea benthic foraminifers from the North Atlantic Ocean have been studied more intensely than similar faunas from other oceans. Pioneering studies of Quaternary faunas were made by Brady (1884-material from the HMS Challenger), Cushman (1923), and Phleger, Parker, and Peirson (1953). Streeter (1973) used the data from the latter authors in a quantitative study and concluded that deep-sea faunal associations of benthic foraminifers are related to the water masses below which they are living, and that the faunal associations changed from glacial to interglacial intervals during the last 150,000 yr. Streeter and Shackleton (1979) compared the faunal composition during the last 150,000 yr. with the oxygen isotopic ratios from tests of Uvigerina species. Schnitker $(1974 ; 1980)$ recognized a similar correlation between water masses and benthic faunal composition in the western North Atlantic, and concluded that Epistominella exigua-dominated faunas are presently typical of the deepocean basins north of $35^{\circ} \mathrm{N}$. South of $35^{\circ} \mathrm{N}$, faunas have abundant Nuttallides umbonifera; faunas typified by Uvigerina and Hoeglundina species occur at somewhat shallower depths along the continental margins and the Mid-Atlantic Ridge. During interglacial periods the faunas resembled the modern ones, but during glacial periods the Uvigerina-Hoeglundina faunas migrated basinward and became dominant in the deep basins north of about $35^{\circ} \mathrm{N}$, while a mixed Uvigerina peregrina-Epistominella exigua fauna lived more to the south, and a

\footnotetext{
${ }^{1}$ Ruddiman, W. F., Kidd, R. B., Thomas, E., et al., Init. Repts. DSDP, 94: Washington (U.S., Govt. Printing Office).

2 Present address: Lamont-Doherty Geological Observatory, Palisades, N.Y. 10964.
}

mixed Epistominella exigua-Nuttallides umbonifera fauna dominated south of $23^{\circ} \mathrm{N}$.

In high-resolution studies of benthic foraminiferal faunas of the Rockall Plateau area, Schnitker (1984) concluded that orbital parameters induced fluctuations in the faunal composition of benthic foraminifers in the late Miocene and during the glacial Pliocene and Pleistocene. The same author (Schnitker, 1982) also described even higher-frequency oscillations in the faunal composition of Quaternary benthic foraminifers (650-2500 yr.).

Older faunas (Paleogene-Recent) from material recovered on DSDP Leg 12 at sites in the North Atlantic and Bay of Biscay were discussed by Berggren (1972). He concluded that there was a major change in deep-sea benthic foraminiferal faunal composition during the middle Miocene, but he did not present data on the exact timing or the sequence of first and last appearances of taxa. Schnitker (1979) studied Paleogene to Recent faunas from the Bay of Biscay (DSDP Leg 48), and concluded that there were major faunal changes at Paleocene/Eocene boundary, at the Eocene/Oligocene boundary, at the Oligocene/Miocene boundary, at the end of the middle Miocene, and in the Pliocene. According to Miller (1983), however, Paleogene faunal changes in the Bay of Biscay occurred over the period from early middle Eocene to earliest Oligocene, and did not coincide with the Eocene/Oligocene boundary.

Murray (1984; and this volume) described and quantitatively analyzed benthic deep-sea faunas from the North Atlantic, including the Rockall Plateau area (DSDP Leg 81). He compared Recent faunas with their older counterparts, and deduced bottom-water movements from the changes in faunal composition with time. Berggren and Schnitker (1983) reviewed the Cretaceous to Recent environmental history of the northeastern North Atlantic, 
and concluded that there was a major taxonomic turnover in the benthic microfauna in the middle Miocene, so that benthic microfaunas assumed their present-day aspect at that time. In Schnitker's paper (in press) on the benthic foraminiferal faunas from the Rockall area and the Bay of Biscay the author also concluded that there was a major faunal turnover in the middle Miocene (15-13 Ma), recognized at depths between 1650 and $4400 \mathrm{~m}$.

A middle Miocene faunal turnover in benthic foraminiferal faunas was described from the Pacific Ocean (Woodruff and Douglas, 1981; Woodruff, 1985). These authors concluded that the major faunal change was coeval with a major increase in $\delta^{18} \mathrm{O}$ values in benthic foraminiferal tests. This increase in benthic $\delta^{18} \mathrm{O}$ values has been recognized worldwide (e.g., Woodruff et al., 1979; Savin et al., 1981; Miller et al., 1985; Pisias et al., 1985; Vincent et al., 1985). Thomas $(1985 ; 1986)$, however, in a study of benthic foraminifers from the eastern equatorial Pacific, decided that the faunal changes at that location were initiated before the middle Miocene increase in oxygen isotopic values, and occurred between 18.5 and $13.5 \mathrm{Ma}$. The beginning of the faunal changes appeared to be correlated with an increase in $\mathrm{CaCO}_{3}$ dissolution, and the onset of an increase in $\delta^{13} \mathrm{C}$ values in benthic and planktonic foraminiferal tests (Vincent and Killingley, 1985; Vincent et al., 1985).

In this chapter I describe benthic foraminiferal faunas from DSDP Sites 608 and 610 (water depths about 3.5 and $2.5 \mathrm{~km}$, respectively, Fig. 1), from an age range of late Oligocene to Recent. The sampling density was highest at Site 608 (generally corresponding to 0.1 to $0.5 \mathrm{~m} . \mathrm{y}$.). At this site the core recovery was good, as was the preservation of the calcareous microfauna. At Site 610 , recovery and preservation were not as good, especially in the deeper part of the hole (lower Miocene), and the site was spot-cored in large intervals in the middle to upper Miocene. The faunas are described generally, and large-scale changes with time are discussed. A more detailed description of the early to middle Miocene events is presented by Thomas (in press). Correlations are made between the faunal record and the oxygen and carbon isotopic records from Site 608 (see Miller et al., this volume), and the ages of the first and last appearances of taxa are determined by extrapolation of the paleomagnetic data in Clement and Robinson (this volume).

\section{MATERIAL AND METHODS}

I used material from DSDP Sites 608 (water depth $3534 \mathrm{~m}, 42^{\circ}$ $50^{\prime} \mathrm{N}, 23^{\circ} 05^{\prime} \mathrm{W}$ ) and 610 (water depth $2427 \mathrm{~m}, 53^{\circ} 13^{\prime} \mathrm{N}, 18^{\circ} 53^{\prime} \mathrm{W}$, see Fig. 1). Hole 608 was cored continuously with the hydraulic piston corer (HPC) to about $150 \mathrm{~m}$ sub-bottom, then cored continuously with the extended core barrel (XCB) to middle Eocene basaltic basement at about $530 \mathrm{~m}$ sub-bottom. In this chapter I describe faunas from the upper $455 \mathrm{~m}$ of the cored section, that is, upper Oligocene to Recent. Below $455 \mathrm{~m}$ (Core 608-49) there is an interval of about $10 \mathrm{~m}$ of sediment with mixed Eocene-Oligocene faunas (see Site 608 report, this volume), representing about $10 \mathrm{~m} . \mathrm{y}$. of time. Below this interval there are middle-upper to upper-middle Eocene sediments on top of the basaltic basement.

Site 610 is situated on Feni Drift, a major sediment drift in the Rockall Trough. I used samples from Holes 610,610A, and 610E to obtain a section that is as complete as possible. Hole 610 was drilled and spot-cored to a final depth of $723 \mathrm{~m}$ in lower Miocene siliceous

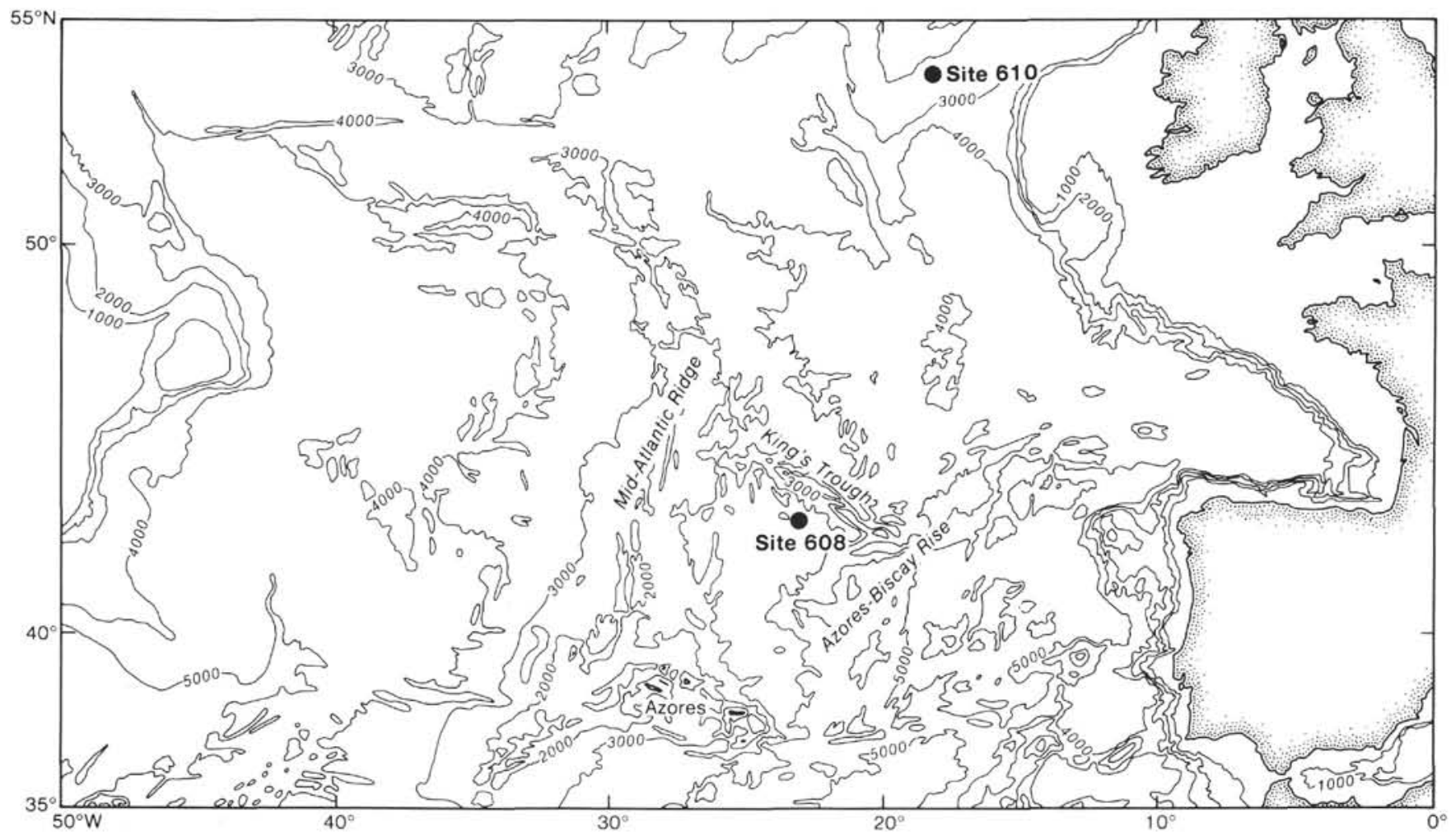

Figure 1. Location map of DSDP Sites 608 and 610 , Leg 94 . The contour interval is $1000 \mathrm{~m}$. 
chalks (NN3, see Takayama and Sato, this volume). Hole 610A is the second HPC hole in the upper part of the section; Holes 610 and $610 \mathrm{~A}$ together give a complete section through the Pleistocene and Pliocene. In Hole 610E seven cores of upper Miocene sediment were recovered. Hole 610 was cored continuously below $635 \mathrm{~m}$ in the lower middle and lower Miocene (9 cores), but recovery was poor (about $50 \%$ ). Overall, large parts of the upper and middle Miocene were not recovered because of spot-coring; in these intervals one core $(9.5 \mathrm{~m})$ was recovered every $50 \mathrm{~m}$ (see Site 610 report, this volume, for the spatial relations between the holes).

From both sites I studied core-catcher samples from sediments younger than about $12 \mathrm{Ma}$ and sediments older than $21 \mathrm{Ma}$, and additional samples from the interval corresponding to 12 to $21 \mathrm{Ma}$ (Appendix A). The sampling interval corresponded to a time interval of about 0.5 m.y. in the upper and lower parts of the section, 0.1 to $0.2 \mathrm{~m} . \mathrm{y}$. in the middle and lower Miocene. Overall, 85 samples from Site 608 and 68 samples from Site 610 were studied. Absolute ages were assigned from extrapolation of the paleomagnetic data presented by Clement and Robinson (this volume), using the time scale of Berggren, Kent, and Flynn (1985) and Berggren, Kent, and Van Couvering (1985). At Site 610 , time control is poor in the spot-cored part of the section (200$600 \mathrm{~m}$ sub-bottom); ages were estimated from the sedimentation-rate curve (see Site 610 report, this volume) and are not reliable.

Samples were washed through a $63-\mu \mathrm{m}$ sieve and air-dried. Indurated chalks in the lower part of Hole 610 (Cores 610-19 through 610-27) were dried at $110^{\circ} \mathrm{C}$, then soaked in kerosene, and heated in water. Some samples in Cores $610-25$ through $610-27$ could not be used because even repeated kerosene treatment did not separate the foraminiferal tests from the chalks. In most samples the preservation of benthic foraminifers was good, with no evidence of dissolution or overgrowths, but in the lower part of Hole 610 many foraminifers were crushed and flattened, and filled with clear, sparry calcite. In general, benthic foraminifers in these samples were better preserved than planktonic foraminifers.

Species-specimen plots were drawn for several samples by plotting the number of species versus the number of specimens while counting. The species-specimen curves become parallel to the species axis at about 180 specimens; in other words, many extra specimens had to be counted to find few extra species. Therefore I decided to obtain about 200 specimens per sample and not to use samples in which fewer specimens were present (note that there is no significant positive correlation between the number of species and the number of specimens in the samples, Fig. 2). Most samples contained sufficient specimens for study, with the exception of samples from the lower part of Hole 610 (see Appendix A for counts).

I made a strewing on a $5 \times 9-\mathrm{cm}$ picking tray to determine how abundant benthic foraminifers were in the sample. If fewer than 5 specimens were present in this strewing, the sample was not used. If more than 5 specimens were present, the amount of sample needed to obtain 200 specimens was estimated, and a split of that size was made in a sample splitter. If not enough specimens were present in the split, extra splits were made. All specimens were picked and mounted in numbered slides. Some of the Cibicidoides spp. specimens were used for isotopic analyses (Miller et al., this volume).

I used the entire size fraction $>63 \mu \mathrm{m}$, because counts were inconsistent when the fraction $>125 \mu \mathrm{m}$ was separated. Some samples have numerous specimens of Stilostomella spp., Pleurostomella spp., or small Bolivina spp., and these linear species can pass through the $125-\mu \mathrm{m}$ sieve. The number of specimens that actually passes, however, depends upon the way in which the sieve is handled (how vigorously shaken, how long shaken). Because the majority of the benthic foraminifers in most samples is $>125 \mu \mathrm{m}$, the results of this study can (with some caution) be compared with studies in which the $>125-\mu \mathrm{m}$ size fraction was used, but not with studies in which the $>250-\mu \mathrm{m}$ fraction was used.

\section{RESULTS}

The counts of all specimens of benthic foraminifers are shown in Appendix A, together with sample numbers, sub-bottom depths, assigned ages, numbers of specimens per sample, and number of species per sample. No assigned ages are shown for the samples from the lower (spot-cored) section of Hole 610 because exact age determinations cannot be made for those samples. The taxonomy is presented in Appendix B.

\section{Diversity}

The diversity, expressed as number of species per sample, is high in most samples, as expected for deep-sea faunas (e.g., Douglas and Woodruff, 1981). Generally there are between 50 and 65 species per 200 specimens. The average number of species is $53( \pm 11)$ at Site 608 , $56( \pm 7)$ at Site 610 ; these numbers are not significantly different. The exception is an interval between about 340 and $355 \mathrm{~m}$ sub-bottom at Site 608, where only 12 to 47 species were found per sample, as a result of extremely high relative abundances of Bolivina spp., especially Bolivina spathulata (see below). A relatively low diversity (39-49 species) was also found in some samples from the glacial intervals of the Pliocene and Pleistocene (recognized as glacial by the presence of ice-rafted material and cold-water planktonic foraminifers; see Weaver, this volume); there is no correlation between the number of species found and sub-bottom depth, or degree of induration of the sediment (Thomas, 1985; in press).

The total number of taxa recognized at the sites is $201 ; 144(71.6 \%)$ of the taxa occur at both sites, 38 $(18.9 \%)$ occur at Site 608 only, $19(9.5 \%)$ at Site 610 only. In total, 182 taxa were recognized at Site 608,163 at Site 610. The "additional" taxa at Site 608 do not occur in the lower part of the section (upper Oligocene), the time equivalent of which was not recovered at Site 610 . Many of the taxa occurring at one site only are rare, with exception of Cassidulina teretis at Site 610, which has a maximum relative abundance of $37 \%$ in some samples younger than $3 \mathrm{Ma}$, and several Fursenkoina species in the lower Miocene of the same site (see Appendix A).

\section{Relative Abundance}

Relative abundances of the most common species and species groups are shown plotted versus sub-bottom depth in Figures 3 (Site 608) and 4A and B (upper and lower part, Site 610); also indicated on these figures are the paleomagnetic chrons after Clement and Robinson (this volume). Figure 5 shows the same data as plotted in Figure 3, but plotted versus absolute age. In Figure 6 the relative abundances of some of the most common species and species groups are shown plotted versus absolute age for Sites 608 and 610 for the last 8 m.y.; a similar plot for the lower part of the holes could not be constructed because the time control for Hole 610 is poor.

The most striking feature of the plots of relative abundance at Site 608 (Figs. 3, 5) is the extremely high relative abundance of Bolivina spp. in Cores 608-37 and -38. Except for this interval, the most common taxa throughout the studied interval at both sites are Oridorsalis spp. (more abundant at Site 608-see Fig. 6). Gyroidinoides spp., unilocular forms, Cibicidoides spp. (the Cibicidoides kullenbergi group together with Cibicidoides bradyi throughout, Cibicidoides wuellerstorfi from the middle Miocene up), and Pullenia spp. The latter taxon was more common at Site 610 after $2.4 \mathrm{Ma}$, from 


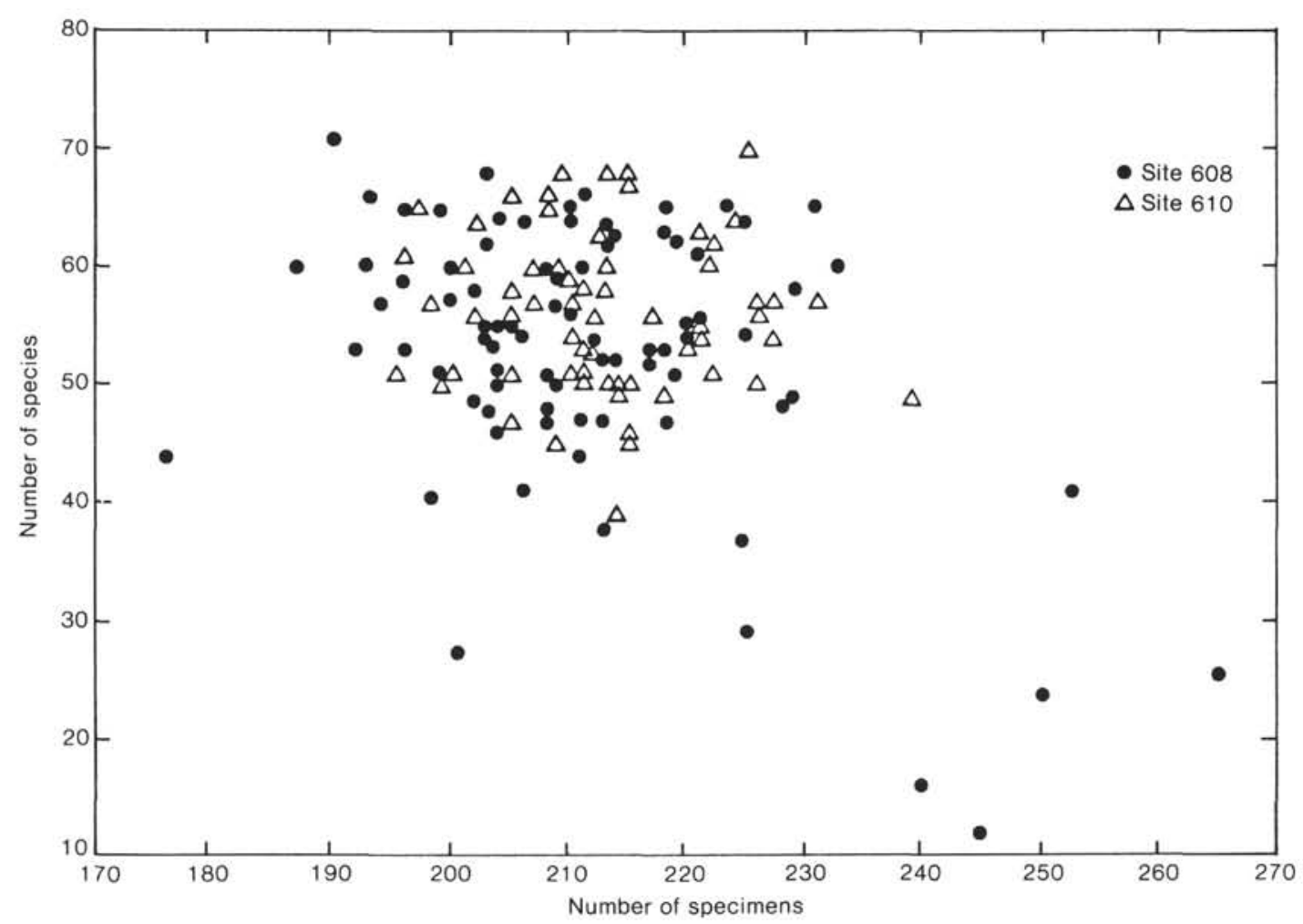

Figure 2. Plot of number of species versus number of specimens for Sites 608 and 610 . Note the absence of a positive correlation.

6 to $8 \mathrm{Ma}$, and before $14 \mathrm{Ma}$ than at other times. Globocassidulina subglobosa is common throughout the section at Site 608, and relatively rare at Site 610, especially above a level corresponding to about $2.4 \mathrm{Ma}$. All these taxa have long ranges and cosmopolitan distributions (e.g., Woodruff and Douglas, 1981; Thomas, 1985; in press).

Nuttallides umbonifera is rare at Site 610, and at Site 608 the taxon had in most samples a relative abundance of less than $5 \%$ before about $6.5 \mathrm{Ma}$; the relative abundance was usually between 5 and $10 \%$ from $6.5 \mathrm{Ma}$ to $1.5 \mathrm{Ma}$, but fluctuated between 0.5 and $23 \%$. After $1.5 \mathrm{Ma}$ N. umbonifera was extremely rare at Site 608 . Epistominella exigua had fluctuating relative abundances at both sites, usually between 2 and $12 \%$, but was more abundant in the mudline sample from Site $608(24 \%)$. Eilohedra weddellensis is absent or very rare in the lower part of the section at both sites; it increased in relative abundance to more than $5 \%$ after $0.8 \mathrm{Ma}$ at Site 608 and $0.2 \mathrm{Ma}$ at Site 610. Cassidulina teretis occurs at Site 610 only, and has strongly fluctuating relative abundances in the sediments from the last 3 m.y., with a maximum value of about $37 \%$.

Melonis spp. are present throughout the section at Site 610 , but had a first appearance at about $20.5 \mathrm{Ma}$ at Site 608. At this site, Melonis spp. had their highest relative abundance between 6 and $15 \mathrm{Ma}$ (relative abundance usually between 5 and $10 \%$ ); the relative abundance decreased after $6 \mathrm{Ma}$. At Site 610 Melonis spp. were usually less abundant than at Site 608 before the Pliocene, but increased in relative abundance after about
$2.8 \mathrm{Ma}$; from 2.8 Ma to Recent, Melonis spp. (mainly Melonis pompilioides) fluctuated strongly in relative abundance, from a few to more than $20 \%$ (Fig. 6).

Pleurostomella spp. constituted 2 to $10 \%$ of the fauna in most samples older than 6.5 Ma at Site 608; they decreased in relative abundance after that time, and species of Pleurostomella are absent from sediment younger than $1.5 \mathrm{Ma}$. At Site 610 they had relative abundances similar to those at Site 608 before about $15 \mathrm{Ma}$, and later constituted less than $5 \%$ of the fauna until about $0.8 \mathrm{Ma}$; they are not found in younger samples. Stilostomella spp. had their last appearance at the same time as Pleurostomella spp. at both sites (1.5 Ma at Site $608,0.8 \mathrm{Ma}$ at Site 610); before that time they formed usually between 5 and $20 \%$ of the total fauna at Site 610 . At Site 608 they were less than $5 \%$ of the fauna from 6 to $1.5 \mathrm{Ma}$, usually similar in relative abundance to the values at Site 610 before $6 \mathrm{Ma}$. Uniserial lagenids at Site 608 decreased in relative abundance from 5 to more than $10 \%$ before about $10 \mathrm{Ma}$ to less than $5 \%$ after that time.

Miliolids are rare or absent in the lower part of the section at both sites. They were consistently present at Site 608 after $12 \mathrm{Ma}$, and increased in relative abundance after $3 \mathrm{Ma}$ (Fig. 6). At Site 610 miliolids increased in relative abundance after about $2.4 \mathrm{Ma}$ (usually 2$10 \%$, Fig. 6).

Bulimina spp. usually had relative abundances of less than $5 \%$ at both sites, but were somewhat more common at Site 610 than at Site 608. Uvigerina spp. fluctuated in relative abundance irregularly at both sites, with 


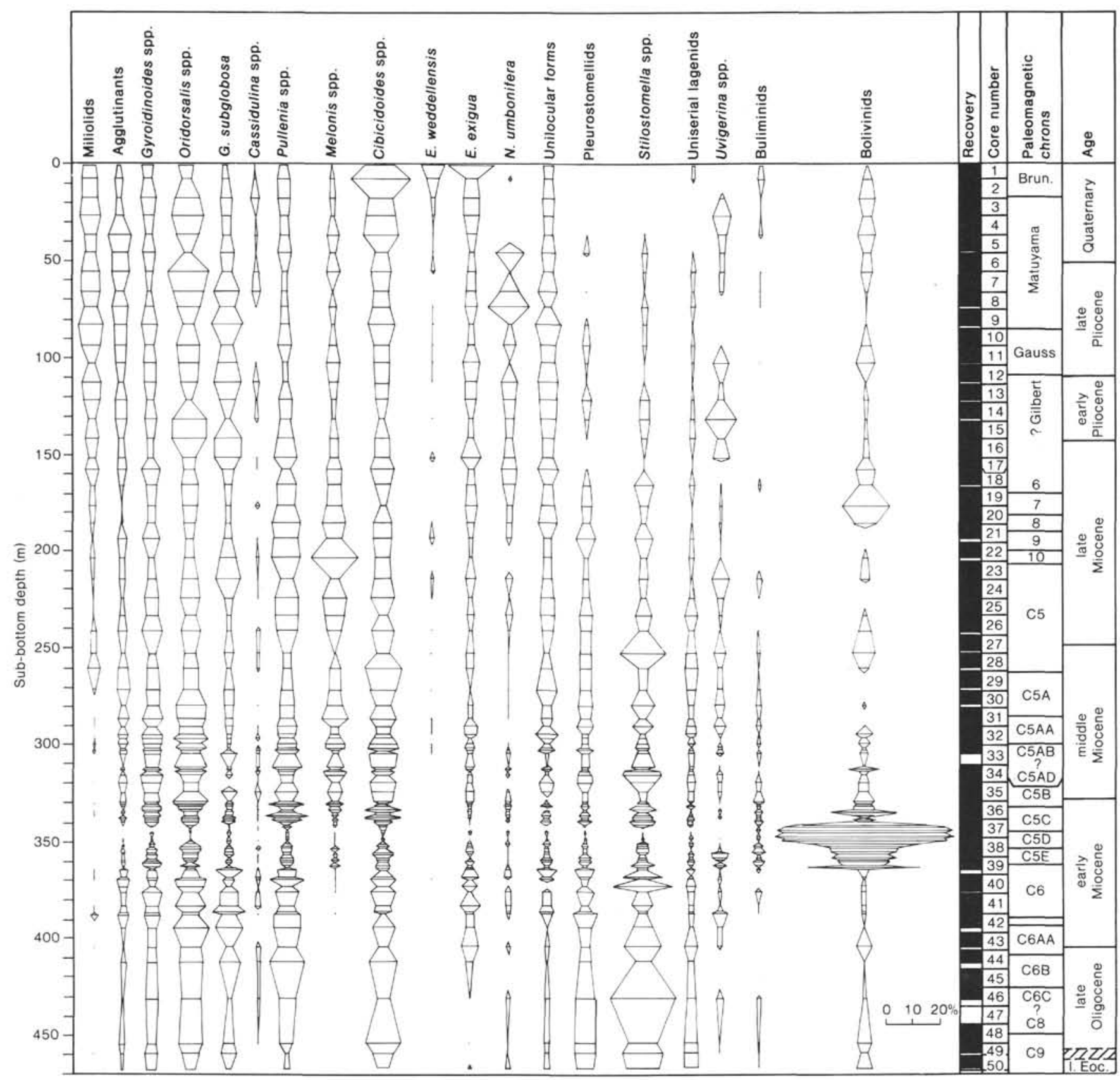

Figure 3. Relative abundances of the most common species and species groups at Site 608, plotted versus sub-bottom depth. Paleomagnetic chrons are after Clement and Robinson (this volume); also indicated are core number and recovery.

Uvigerina peregrina increasing in relative abundance after about 6.5 Ma at Site 610, somewhat later (5.5-6.0 Ma) at Site 608 (Appendix A, Tables 1, 2).

At Site 608 extremely high percentages of Bolivina spp. were noted in Cores 608-37 and -38 (Figs. 3, 5); the Bolivina are predominantly Bolivina spathulata, but at some levels also Bolivina striatula and Bulivina pseudoplicata (Thomas, in press). It is unlikely that these high relative abundances are the result of downslope transport: the Bolivina specimens have thin, delicate tests and do not show signs of abrasion. At different levels in the cores different species of Bolivina are predominant (Thomas, in press); in some sediments recognized as de- bris flows by shipboard scientists (see Site 608 report, this volume) the faunas do not have abundant Bolivina. The highest relative abundances of Bolivina (more than $90 \%$ ) occur in Cores $608-37$ and -38 (341-351 m subbottom); this level is in calcareous nannofossil Zone NN4 (Takayama and Sato, this volume), and paleomagnetic Chrons C5C-C5E (Clement and Robinson, this volume; see also Fig. 3); the estimated age is 17 to $18.2 \mathrm{Ma}$. The lowest peak in relative abundance of Bolivina occurs in Core 608-39, at about $363 \mathrm{~m}$ sub-bottom (about 19.2 Ma; Fig. 5). Bolivina spp. relative abundances fluctuated considerably during the Miocene, with peaks of Bolivina spathulata and Bolivina striatula (together more 


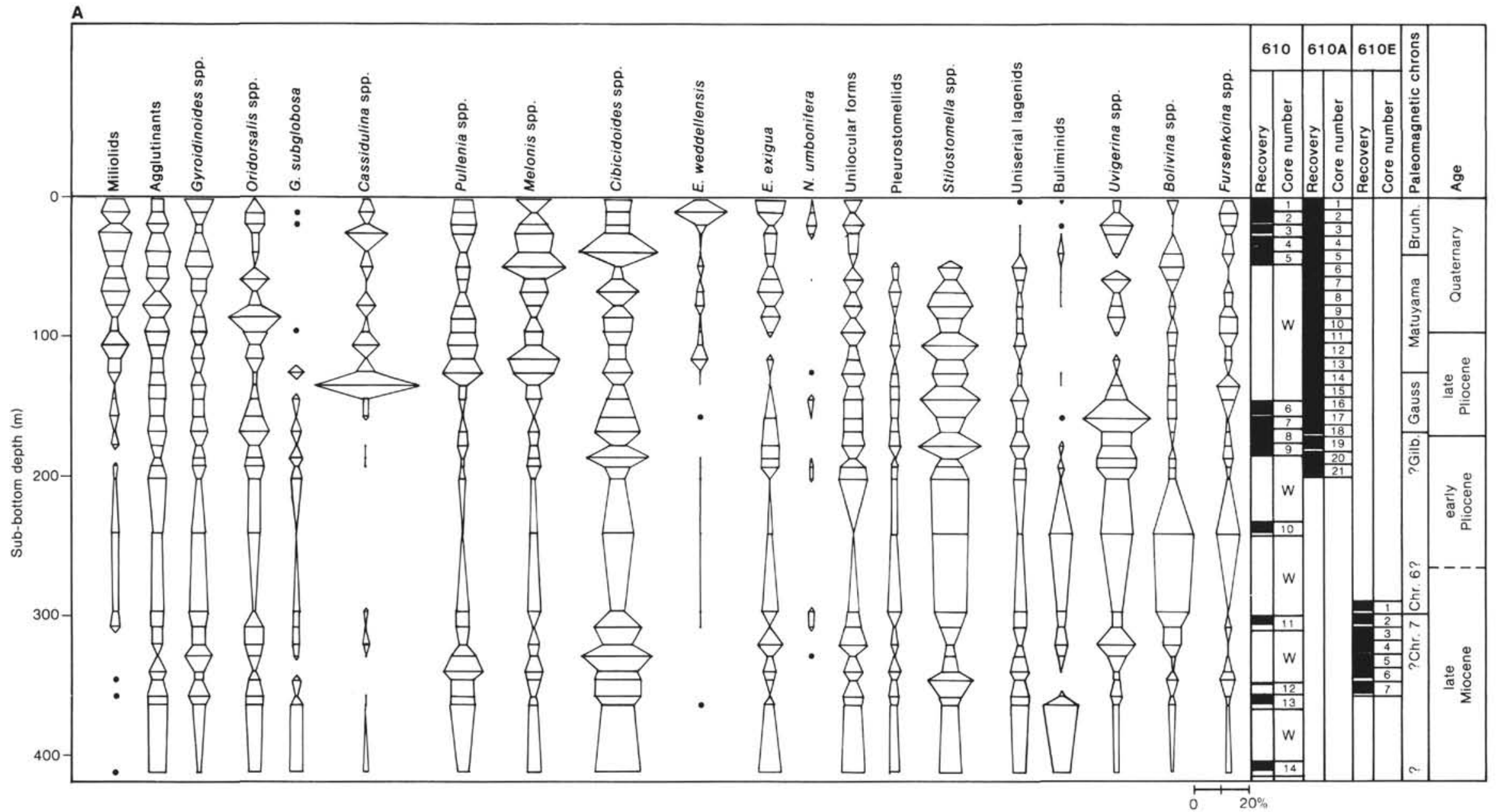




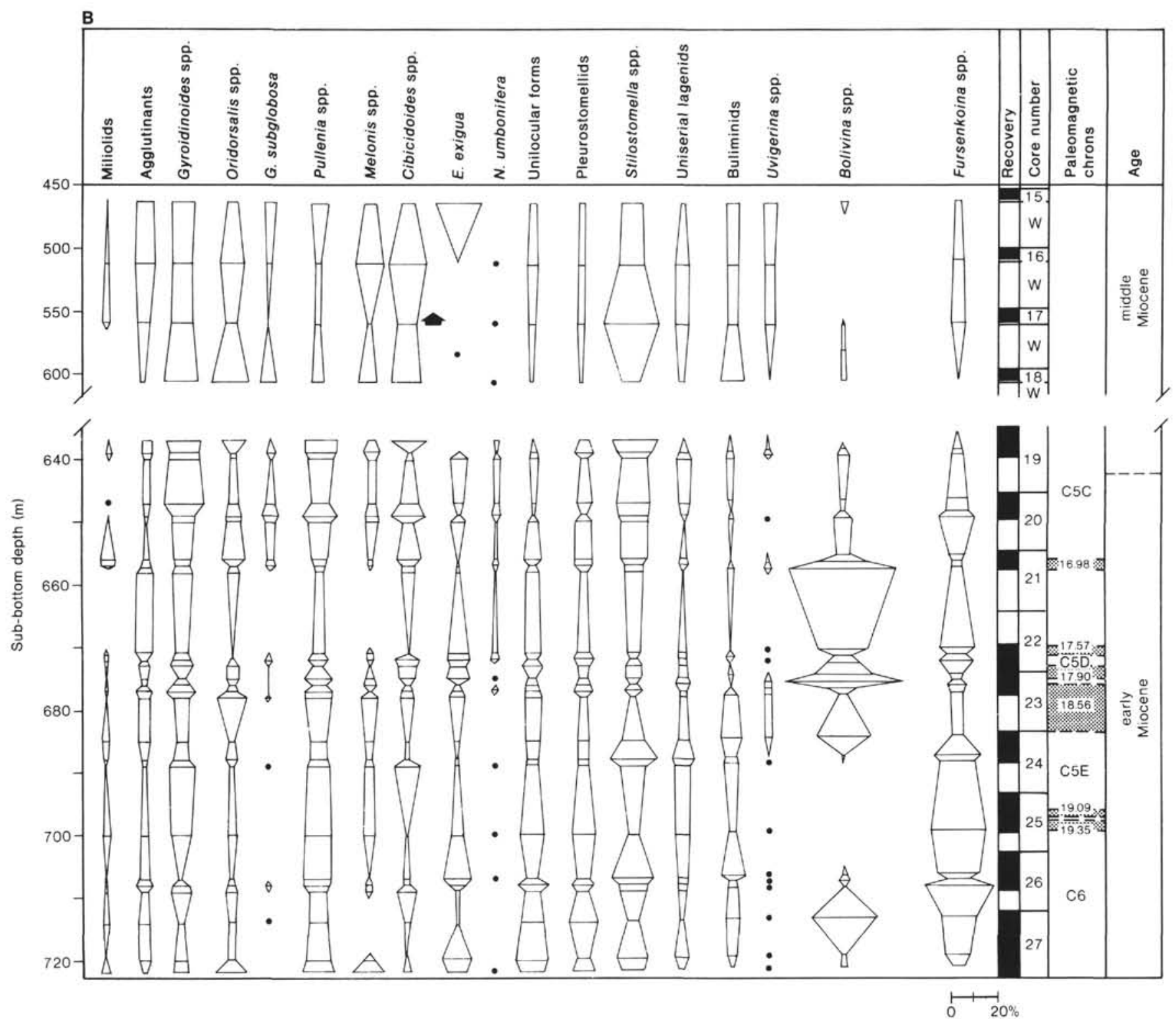

Figure 4. Relative abundances of the most common species and species groups at Site 610, plotted versus sub-bottom depth for the upper part (A) and the lower part (B) of the section. Indicated are core number and recovery for Holes 610, 610A, and 610E (W in Core number column indicates washed section). The sub-bottom depths for Hole $610 \mathrm{E}$ have been adjusted by $30 \mathrm{~m}$, to make up indicates the FA of Cibicidoides wuellerstorfi; the shaded intervals in the Paleomagnetic chron column indicate the depth interval in which the reversal boundary occurs; numbers give the age, indicates the FA of Cibicidoides wuellerstorf
following Berggren, Kent, and Flynn (1985). 


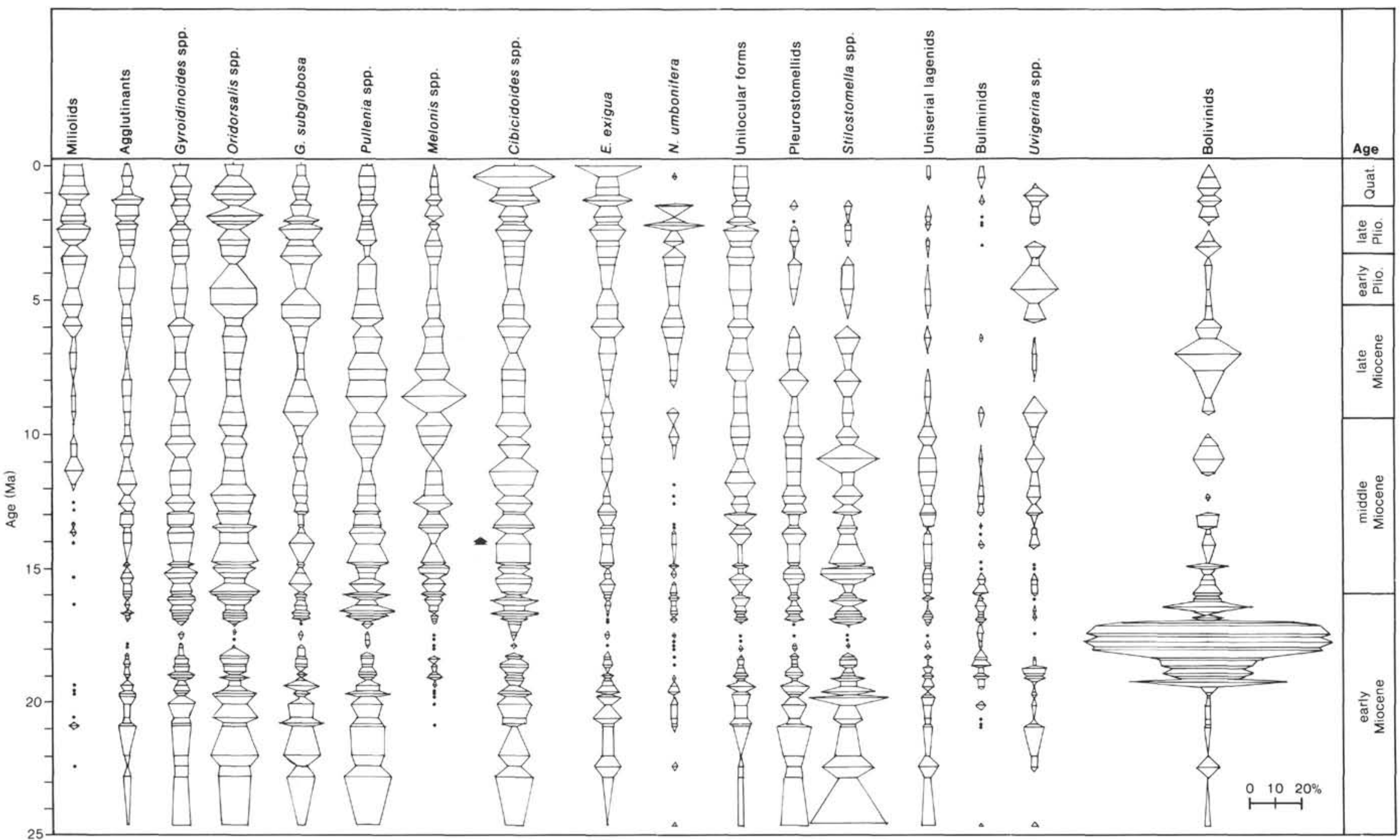

Figure 5. Relative abundances of the most common species and species groups at Site 608, plotted versus time. The age model was constructed using the paleomagnetic data of Clement and Robinson (this volume) and the time scale of Berggren, Kent, and Van Couvering (1985). The arrow indicates the FA of Cibicidoides wuellerstorfi. 
than $30 \%)$ at $334 \mathrm{~m}$ sub-bottom ( $\sim 16.4 \mathrm{Ma})$, of Bolivina striatula and Bolivina pseudoplicata (together 16\%) at $312 \mathrm{~m}$ sub-bottom ( $\sim 14.9 \mathrm{Ma})$, and of Bolivina translucens $(25 \%)$ at $176 \mathrm{~m}(\sim 7 \mathrm{Ma})$.

At Site 610 the relative abundances of Bolivina spp. are never as high as at Site 608 , but Bolivina spathulata is relatively abundant (up to $45 \%$ ) in Cores $610-21,-22$, and the top of -23 . This interval is (within the limits of resolution of this study) coeval with the level of highest relative abundances of Bolivina at Site 608, that is, within calcareous nannofossil Zone NN4 (Takayama and Sato, this volume), and paleomagnetic Chrons C5C-C5E (Clement and Robinson, this volume; see also Fig. 4B): the estimated age is 17 to $18.5 \mathrm{Ma}$. In this interval and just below, Fursenkoina spp. are also relatively abundant at Site 610 (up to $27 \%$, but usually $10-15 \%$ ); the genus decreased in relative abundance at the end of the early Miocene (it is rare at Site 608).

In conclusion, there were changes in relative abundances between 19.2 and $17 \mathrm{Ma}$ (increase in Bolivina at both sites, more extreme at Site 608 ), between 14 and 15 Ma (decrease in Pleurostomella at Site 610, increase in Melonis at Site 608), from 10 to $9 \mathrm{Ma}$ (decrease in uniserial lagenids at Site 608), between 5 and $7 \mathrm{Ma}$ (increase in miliolids and Nuttallides umbonifera, decrease in Pleurostomella, Stilostomella, and Melonis at Site 608), and during the last $3 \mathrm{~m} . \mathrm{y}$. (more miliolids at Site 610, less Nuttallides umbonifera at Site 608, last appearances of Stilostomella and Pleurostomella at both sites, increase in Cassidulina teretis and Melonis at Site 610, increase in Eilohedra weddellensis at both sites).

\section{First and Last Appearances (FAs and LAs)}

FAs and LAs are difficult to determine with accuracy and precision for deep-sea benthic foraminiferal species, because the most common species have long ranges and do not have FAs or LAs in the studied interval (i.e., late Oligocene to Recent). For rare species the exact position at which FAs and LAs are actually found may be considerably different from the real position, because the probability of actually finding a rare species is low. I used FAs and LAs of species that have a reasonably welldefined consecutive range, that is, the rarest species were not used. The position of all FAs and LAs used are given in Tables 1 (Site 608) and 2 (Site 610), and ranges of selected species are shown in Figure 7. Listed are all the FAs and LAs observed, whether they are a result of migration (immigration or emigration, lateral or vertical migration) or evolution (evolution or extinction). At present there are not enough data available on deep-sea benthic foraminiferal faunas from all oceans to determine whether a specific faunal event (FA or LA) is local, regional, or global, especially because of the confusion in taxonomy, which makes comparison with data of other authors difficult. I decided to list all faunal events that are recognizable at Sites 608 and 610 to find out if these events are evenly distributed through time or concentrated in specific periods. If faunal events cluster in some periods, then the clustering probably indicates changes in the deep-sea environment in these periods, whether the benthic foraminifers reacted by evolution or migration. Figure 8 is a cumulative plot of faunal events versus time for Site 608 and 610 .

Of the 182 taxa recorded at Site 608, 39 are longranging, 101 are too rare to determine whether they have a FA or LA, 24 taxa have a FA, and 21 a LA ( 3 species have a FA and a LA; a total of 45 faunal events). At Site 610,42 of the recognized taxa range throughout the section, 77 are too rare to determine a FA or LA, 23 have a FA, and 25 a LA ( 4 species have both a FA and a LA; a total of 48 faunal events). The long-ranging taxa comprise about 50 to $60 \%$ of the total fauna in most samples.

In my opinion, it is presently not possible to compare data on ranges of most species with data from other authors without comparing the actual material because of taxonomical problems. Therefore the following discussion is not meant to give an overview of all available data, but to compare the data from a deeper site (Site 608) with those of a shallower Atlantic site (Site 610), and the data from the two Atlantic sites with data from the $\mathrm{Pa}$ cific (Thomas, 1985). Of all faunal events, 8 only occurred in the same calcareous nannofossil zone at Sites 608 and 610 (see Tables 1 and 2), that is, 3 in NN19 (LA Pleurostomella obtusa, LA Stilostomella annulifera, and LA Stilostomella lepidula), 3 in NN11 (FA Pyrgo murrhina, FA Bolivina translucens, LA Nonion havanense), 1 in NN5 (FA Cibicidoides wuellerstorfi), and 1 in NN3 (FA Ehrenbergina caribbea). The FA of $C$. wuellerstorfi (14.1-14.8 Ma at Site 608) occurred at a similar time, but probably slightly earlier, in the equatorial Pacific (15.0-15.6 Ma) (Thomas, 1985). This FA is coeval with the increase in oxygen isotopic ratios in the tests of benthic foraminifers at Site 608 (Miller et al., this volume). The FA of Ehrenbergina caribbea at 17 to $20 \mathrm{Ma}$ in the equatorial Pacific may correlate with this event at Atlantic Sites 608 and 610 (18.7-19.0 Ma). Several other faunal events at the deepest Atlantic site (Site 608) might be correlated with the same faunal events in the deep equatorial Pacific, for example, the FA of the Melonis barleeanus group at about $20 \mathrm{Ma}$ (Thomas, 1986).

Overall, few of the faunal events can be correlated in time between Site $608(3.5 \mathrm{~km})$ and Site $610(2.5 \mathrm{~km})$, or between the northeast Atlantic and DSDP Sites 573, 574 , and 575 in the equatorial Pacific, although the faunal patterns are similar: for instance, Stilostomella spp., Pleurostomella spp., and the uniserial lagenids decrease in abundance at all these sites. The timing, however, is different at different depths and in different areas.

Faunal events are not evenly distributed through time (Fig. 8). The event rate, that is, the number of faunal events per time unit, was low at Sites 608 and 610 before about $19 \mathrm{Ma}$, with a small increase associated with the strong increase in relative abundance of Bolivina spp. An increase in the event rate occurred at both sites between about 13.5 and $15.5 \mathrm{Ma}$, but the precise time cannot be determined at Site 610 because this interval was spot-cored. This increase can be correlated at Site 608 with the increase in oxygen isotopic ratios in benthic foraminiferal tests in the lower middle Miocene (Miller et al., this volume; Fig. 8), which has been observed world- 


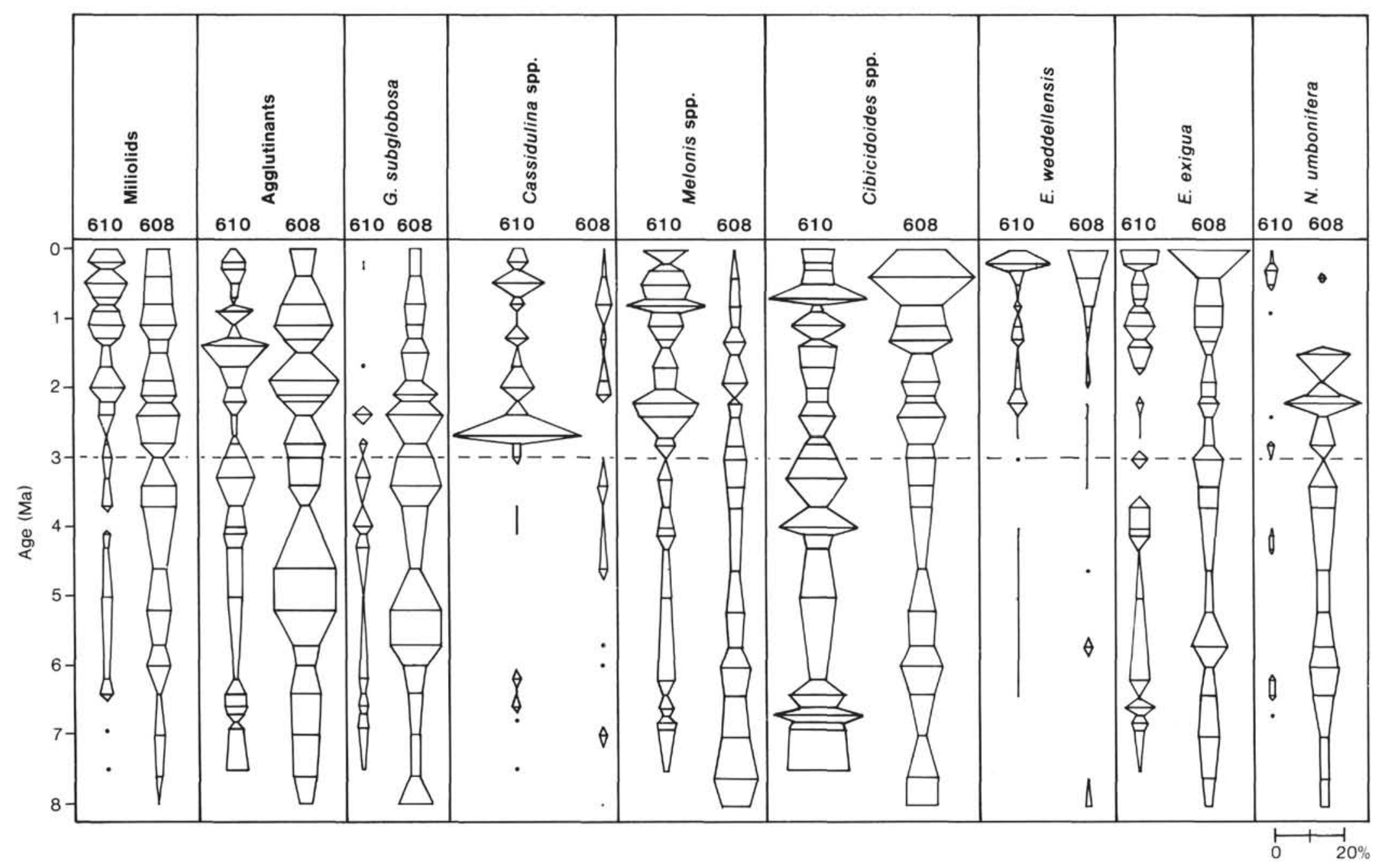




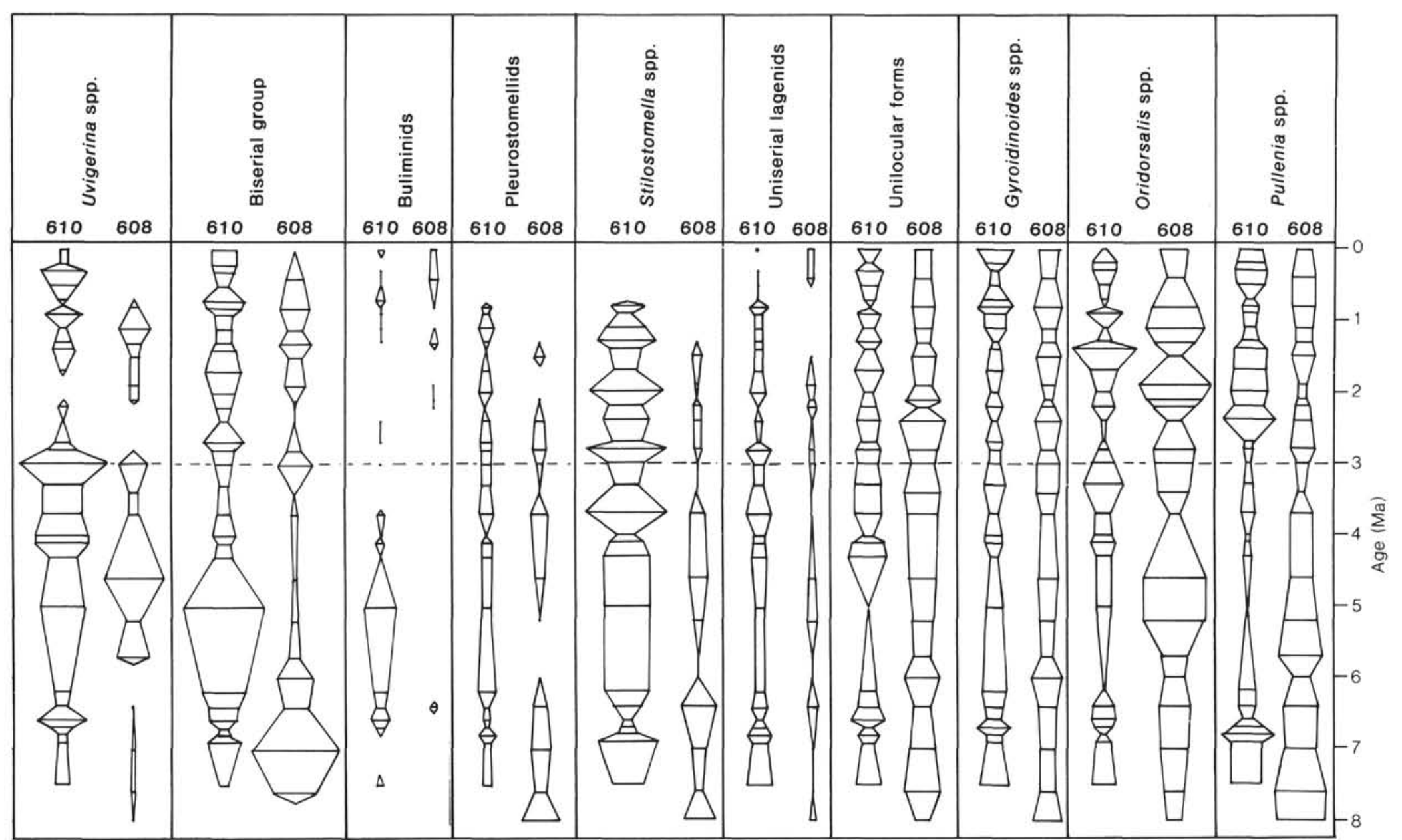

Figure 6. Relative abundances of the most common species and species groups at Sites 608 and 610 , plotted versus time for the last 8 m.y. The age models were constructed using the paleomagnetic data of Clement and Robinson (this volume) and the time scale of Berggren, Kent, and Van Couvering (1985). 
Table 1. First and last appearances (FAs and LAs) of taxa at Site 608.

\begin{tabular}{|c|c|c|c|}
\hline Event & Sample & $\mathrm{CNZ}$ & Age (Ma) \\
\hline LA Eponides tumidulus & $2, \mathrm{CC}$ & NN19 & $0.8-1.1$ \\
\hline FA Eponides repandus & $3, \mathrm{CC}$ & NN19 & $1.1-1.3$ \\
\hline LA Pleurostomella obtusa ${ }^{\mathrm{a}}$ & $4, \mathrm{CC}$ & NN19 & $1.1-1.3$ \\
\hline LA Stilostomella annulifera ${ }^{\text {a }}$ & $4, \mathrm{CC}$ & NN19 & $1.1-1.3$ \\
\hline LA Stilostomella lepidula ${ }^{\mathrm{a}}$ & $4, \mathrm{CC}$ & NN19 & $1.1-1.3$ \\
\hline FA Cibicides variabilis & $4, \mathrm{CC}$ & NN19 & $1.3-1.5$ \\
\hline LA Pleurostomella acuminata & $5, \mathrm{CC}$ & NN16 & $1.3-1.5$ \\
\hline LA Bolivina pseudoplicata & $5, \mathrm{CC}$ & NN16 & $1.3-1.5$ \\
\hline LA Pleurostomella alternans & $5, \mathrm{CC}$ & NN16 & $1.3-1.5$ \\
\hline LA Pleurostomella bolivinoides & $5, \mathrm{CC}$ & NN16 & $1.3-1.5$ \\
\hline FA Ehrenbergina trigona & $5, \mathrm{CC}$ & NN16 & $1.5-1.9$ \\
\hline FA Stainforthia complanata & $6, \mathrm{CC}$ & NN16 & $1.9-2.1$ \\
\hline FA Pyrgo elongata & $10, \mathrm{CC}$ & NN16 & $2.8-3.0$ \\
\hline FA Pyrgo lucernula & $10, \mathrm{CC}$ & NN16 & $2.8-3.0$ \\
\hline LA Ehrenbergina caribbea & $11, \mathrm{CC}$ & NN16 & $2.8-3.0$ \\
\hline LA Uvigerina graciliformis & $11, \mathrm{CC}$ & NN16 & $2.8-3.0$ \\
\hline FA Sigmoilopsis schlumbergeri & $11, \mathrm{CC}$ & NN16 & $3.0-3.4$ \\
\hline FA Quinqueloculina pygmaea & $13, \mathrm{CC}$ & NN15 & $3.7-4.6$ \\
\hline LA Stilostomella subspinosa & $14, \mathrm{CC}$ & NN14 & $3.7-4.6$ \\
\hline LA Bigenerina nodosaria & $16, \mathrm{CC}$ & $\mathrm{NN} 12-13$ & $5.2-5.6$ \\
\hline FA Uvigerina peregrina ${ }^{b}$ & $16, \mathrm{CC}$ & NN12-13 & $5.2-5.6$ \\
\hline LA Stilostomella abyssorum & $18, \mathrm{CC}$ & NN11 & $6.0-6.4$ \\
\hline LA Pyrgo murrhina ${ }^{\mathrm{a}}$ & $18, \mathrm{CC}$ & NN11 & $6.4-7.0$ \\
\hline FA Bolivina translucens ${ }^{\mathrm{a}, \mathrm{b}}$ & $20, \mathrm{CC}$ & NN11 & $7.6-8.0$ \\
\hline LA Nonion havanense ${ }^{\mathrm{a}}$ & $21, \mathrm{CC}$ & NN11 & $7.6-8.0$ \\
\hline LA Bolivina striatula & 23, CC & NN9 & $8.6-9.2$ \\
\hline LA Bulimina alazanensis & $23, \mathrm{CC}$ & NN9 & $8.6-9.2$ \\
\hline LA Anomalina alazanensis spissiformis ${ }^{b}$ & $24, \mathrm{CC}$ & NN9 & $9.2-9.7$ \\
\hline LA Bolivinopsis cubensis & $28, \mathrm{CC}$ & NN8 & $10.9-11.4$ \\
\hline FA Sigmoilina tenuis & $28, \mathrm{CC}$ & NN8 & $11.4-11.9$ \\
\hline FA Melonis pompilioides & $31-4$ & NN6 & $12.6-12.9$ \\
\hline LA Cibicidoides laurisae & $32-3$ & NN6 & $12.9-13.0$ \\
\hline LA Cibicidoides havanense & $33, \mathrm{CC}$ & NN5 & $13.7-14.1$ \\
\hline FA Eilohedra weddellensis & $33-2$ & NN5 & $13.7-14.1$ \\
\hline FA Cibicidoides wuellerstorfi ${ }^{\mathrm{a}}$ & $33, \mathrm{CC}$ & NN5 & $14.1-14.8$ \\
\hline FA Ophthalmidium pusillum & $33, \mathrm{CC}$ & NN5 & $14.1-14.8$ \\
\hline LA Cibicidoides perlucidus & $34-1$ & NN5 & $14.1-14.8$ \\
\hline LA Gyroidinoides girardanus & $34-2$ & NN5 & $14.8-14.9$ \\
\hline LA Bolivina spathulata & $36-2$ & NN4 & $16.0-16.1$ \\
\hline LA Pleurostomella acuta & $36-2$ & NN4 & $16.0-16.1$ \\
\hline FA Cibicidoides cicatricosus & $36-5$ & NN4 & $16.6-16.7$ \\
\hline FA Ehrenbergina caribbea ${ }^{\mathrm{a}}$ & $38, \mathrm{CC}$ & NN3 & $18.8-18.9$ \\
\hline FA Bolivina spathulata & $40-1$ & NN3 & $19.6-19.7$ \\
\hline FA Melonis affinis & $40, \mathrm{CC}$ & NN3 & $20.1-20.6$ \\
\hline FA Bolivina striatula & $42, \mathrm{CC}$ & NN3 & $22.0-22.4$ \\
\hline
\end{tabular}

Note: Ages are from extrapolation of the paleomagnetic data of Clement and Robinson (this volume); calcareous nannofossil zones (CNZ) are after Takayama and Sato (this volume).

a Events that occur in the same nannofossil zone at Site 610.

b An increase or decrease in abundance.

wide (Woodruff and Douglas, 1981; Savin et al., 1981). At Site 610 the event rate was low between 13.5 and 7 $\mathrm{Ma}$, and it increased sharply between 7 and $6 \mathrm{Ma}$, between 3.3 and $2.0 \mathrm{Ma}$, and 1.3 and $0.7 \mathrm{Ma}$. At Site 608 the event rate was stable between 13.5 and $3 \mathrm{Ma}$ (except for a possible small increase at 10-9 Ma), but somewhat higher than before $15 \mathrm{Ma}$, and there was no increase in the event rate between 7 and $6 \mathrm{Ma}$. Therefore the difference between the event rate curves at Sites 608 and 610 increased between 13.5 and $7 \mathrm{Ma}$, to decrease again at $7 \mathrm{Ma}$ (Fig. 8B). The cumulative curves of faunal events at the two sites have a relatively constant difference of 5 events between 3.5 and $6.5 \mathrm{Ma}$; this difference exists because there were more events at Site 610 at about $3 \mathrm{Ma}$ than there were at Site 608 , although the event rate at Site 608 increased sharply between 3.0 and $2.8 \mathrm{Ma}$, and between 1.5 and $1.1 \mathrm{Ma}$.

The variation in the event rates is also demonstrated in Figure 9, where the midpoints of the ranges of FAs
Table 2. First and last appearances (FAs and LAs) of taxa at Site 610.

\begin{tabular}{|c|c|c|c|}
\hline Event & Sample & $\mathrm{CNZ}$ & Age (Ma) \\
\hline LA Chrysalogonium tenuicostatum & $5, \mathrm{CC}$ & NN19 & $0.7-0.8$ \\
\hline LA Stilostomella consobrina & $5, \mathrm{CC}$ & NN19 & $0.7-0.8$ \\
\hline LA Stilostomella lepidula ${ }^{\mathrm{a}}$ & $5, \mathrm{CC}$ & NN19 & $0.7-0.8$ \\
\hline LA Pleurostomella bolivinoides & $5, \mathrm{CC}$ & NN19 & $0.7-0.8$ \\
\hline LA Pleurostomella acuminata & A6,CC & NN19 & $0.8-0.9$ \\
\hline LA Stilostomella annulifera ${ }^{\mathrm{a}}$ & $\mathrm{A} 7, \mathrm{CC}$ & NN19 & $0.9-1.1$ \\
\hline LA Orthomorphina glandigena & $\mathrm{A} 7, \mathrm{CC}$ & NN19 & $0.9-1.1$ \\
\hline FA Bolivina subspinescens & $\mathrm{A} 7, \mathrm{CC}$ & NN19 & $1.1-1.3$ \\
\hline LA Textularia agglutinans & $\mathrm{A} 8, \mathrm{CC}$ & NN19 & $1.1-1.3$ \\
\hline LA Pleurostomella obtusa ${ }^{\mathrm{a}}$ & $\mathrm{A} 10, \mathrm{CC}$ & NN19 & $1.4-1.7$ \\
\hline LA Bolivina spathulata & $\mathrm{A} 11, \mathrm{CC}$ & NN18 & $1.7-2.0$ \\
\hline FA Eponides tumidulus & $\mathrm{A} 12, \mathrm{CC}$ & NN18 & $2.2-2.4$ \\
\hline FA Pyrgo elongata & $\mathrm{A} 12, \mathrm{CC}$ & NN18 & $2.2-2.4$ \\
\hline FA Hopkinsina pacifica & $\mathrm{A} 13, \mathrm{CC}$ & NN18 & $2.4-2.7$ \\
\hline FA Hoeglundina elegans & $\mathrm{A} 13, \mathrm{CC}$ & NN18 & $2.4-2.7$ \\
\hline LA Bulimina microcostata & $\mathrm{A} 14, \mathrm{CC}$ & NN17 & $2.4-2.7$ \\
\hline FA Cassidulina teretis & $6, \mathrm{CC}$ & ?NN16 & $3.0-3.3$ \\
\hline FA Melonis barleeanus & $6, \mathrm{CC}$ & ?NN16 & $3.0-3.3$ \\
\hline LA Ehrenbergina trigona & $7, \mathrm{CC}$ & ?NN16 & $3.0-3.3$ \\
\hline LA Melonis affinis & $7, \mathrm{CC}$ & ?NN16 & $3.0-3.3$ \\
\hline FA Uvigerina bononiensis & $7, \mathrm{CC}$ & ?NN16 & $3.0-3.3$ \\
\hline LA Ehrenbergina caribbea & $\mathrm{A} 20, \mathrm{CC}$ & NN15 & $4.0-4.1$ \\
\hline FA Melonis pompilioides & $\mathrm{A} 21, \mathrm{CC}$ & NN15 & $4.3-5.0$ \\
\hline FA Stainforthia complanata & $10, \mathrm{CC}$ & $?$ & $5.0-6.2$ \\
\hline LA Cibicidoides trinitatensis & E1,CC & NN12 & $5.0-6.2$ \\
\hline LA Fursenkoina cylindrica & $\mathrm{E} 1, \mathrm{CC}$ & NN12 & $5.0-6.2$ \\
\hline LA Cibicidoides cf. kullenbergi & $\mathrm{E} 2, \mathrm{CC}$ & NN11 & $6.2-6.4$ \\
\hline FA Pyrgo murrhina $a^{\mathrm{a}}$ & $\mathrm{E} 2, \mathrm{CC}$ & NN11 & $6.4-6.6$ \\
\hline FA Eilohedra weddellensis & $\mathrm{E} 2, \mathrm{CC}$ & NN11 & $6.4-6.6$ \\
\hline LA Nonion havanense & $\mathrm{E} 3, \mathrm{CC}$ & NN11 & $6.4-6.6$ \\
\hline FA Ehrenbergina trigona & $\mathrm{E} 3, \mathrm{CC}$ & NN11 & $6.6-6.7$ \\
\hline FA Uvigerina peregrina ${ }^{\mathrm{b}}$ & $\mathrm{E} 4, \mathrm{CC}$ & NN11 & $6.7-6.8$ \\
\hline FA Cibicidoides cicatricosus & $\mathrm{E} 5, \mathrm{CC}$ & NN11 & $6.8-6.9$ \\
\hline FA Pyrgo lucernula & $\mathrm{E} 5, \mathrm{CC}$ & NN11 & $6.8-6.9$ \\
\hline FA Bolivina translucens ${ }^{\mathrm{a}, \mathrm{b}}$ & E6,CC & NN11 & $6.9-7.5$ \\
\hline LA Pleurostomella alternans & $14, \mathrm{CC}$ & ?NN9 & $8.6-10.5$ \\
\hline FA Uvigerina bononiensis & $15, \mathrm{CC}$ & $?$ & $12.0-13.5$ \\
\hline LA Anomalina alazanensis spissiformis ${ }^{\mathrm{b}}$ & $16, \mathrm{CC}$ & NN6 & $12.0-13.5$ \\
\hline FA Francesita advena & $16, \mathrm{CC}$ & NN6 & $13.5-14.5$ \\
\hline LA Bolivinopsis cubensis & $17, \mathrm{CC}$ & NN5 & $13.5-14.5$ \\
\hline FA Sigmoilopsis schlumbergeri & $17, \mathrm{CC}$ & NN5 & $14.5-15.5$ \\
\hline FA Cibicidoides wuellerstorf $i^{\mathrm{a}}$ & $17, \mathrm{CC}$ & NN5 & $14.5-15.5$ \\
\hline LA Pleurostomella acuta & $19-1$ & NN5 & $15.3-15.4$ \\
\hline LA Fursenkoina mexicana & $19-2 \mathrm{C}$ & NN5 & $15.3-15.4$ \\
\hline FA Bulimina elongata subulata & $19, \mathrm{CC}$ & NN5 & $15.5-15.9$ \\
\hline FA Stilostomella annulifera & $24-1$ & NN3 & $18.7-18.8$ \\
\hline FA Ehrenbergina caribbea ${ }^{\mathrm{a}}$ & $24-3$ & NN3 & $18.9-19.0$ \\
\hline LA Bigenerina nodosaria & 26-4 & NN3 & $19.5-19.6$ \\
\hline
\end{tabular}

Note: Ages are from extrapolation of the paleomagnetic data of Clement and Robinson (this volume), (ages in the spot-cored interval are not accurate). Calcareous nannofossil zones (CNZ) are after Takayama and Sato (this volume).

${ }^{a}$ Events that occur in the same nannofossil zone at Site 608.

${ }^{b}$ An increase or decrease in abundance.

and LAs were plotted versus time in a histogram with a unit width of $0.5 \mathrm{~m}$.y. Obviously the largest number of FAs and LAs occurred between 0.5 and $3.5 \mathrm{Ma}$ at both sites: from the 45 faunal events at Site 608,17 events $(38 \%)$ occurred during this period, and for Site 610 the numbers are $21(44 \%)$ out of 48 . At Site 61011 events out of $48(23 \%)$ occurred between 7 and $5.5 \mathrm{Ma}$, at which time there was no concentration of FAs or LAs at Site 608. A third period with relatively many faunal events was between 13.5 and $15.5 \mathrm{Ma}$ at Site 608 (6 events i.e., 13\%), and between 14 and $15.5 \mathrm{Ma}$ at Site $610(6$ events, $12.5 \%)$. The apparent difference in age is probably the result of the poor time control at Site 610 .

In counting FAs and LAs as a measure of faunal change, the FAs and LAs of relatively rare species re- 
ceive as much weight as those of more common species, but the latter have more impact on the total aspect of the fauna: the FA of Cibicidoides wuellerstorfi, for instance, is of more importance for the total fauna than the LA of Nonion havanense. Thomas (1986) discussed the concept of similarity of a fauna in a sample to a fauna in a mudline sample from the same site; the similarity was defined as the percentage of specimens in a sample that belongs to species that are found in a mudline sample from the same site. At Site 608 the similarity of the fauna increased from 60 to $70 \%$ in the late Oligocene (similar to a figure of $67.5 \%$ for Oligocene assemblages as given by Boltovskoy, in press) to 70 to $80 \%$ at 15 to $14 \mathrm{Ma}$, then changed gradually and with large fluctuations to about $90 \%$ similarity at about $6 \mathrm{Ma}$. These numbers emphasize that a large proportion of the total fauna belonged to long-ranging species, and that the occurrence of FAs and LAs does not have to mean an important change in the total aspect of the fauna (Boltovskoy, 1980a and 1980b).

\section{DISCUSSION}

About $60 \%$ of the total deep-sea benthic foraminiferal faunas at Site 608 and 610 belongs to long-ranging species, existing since at least the late Oligocene. Faunal events can generally not be correlated from one site to another site (especially to another site at different depth or in another basin): only eight out of the 45 events at Site 608, and of the 48 events at Site 610 , occurred in the same calcareous nannofossil zone at Sites 608 and 610 (Tables 1 and 2). All other events are recognized at one site only, or the timing is different. The FA of Sigmoilopsis schlumbergeri, for instance, occurred at 14.5 to $15 \mathrm{Ma}$ at Site 610 (depth about $2.5 \mathrm{~km}$ ), and at 3.0 to $3.4 \mathrm{Ma}$ at Site 608 (depth about $3.5 \mathrm{~km}$ ). This species was recorded by Schnitker (in press) to have a FA at $14 \mathrm{Ma}$, in his discussion of benthic foraminiferal faunas from DSDP Sites 552 to 555 (Rockall Plateau area, 1600-3000 m water depth) and DSDP Site 400 (Bay of Biscay, $4400 \mathrm{~m}$ ). Several other faunal events described in Schnitker (in press) occurred at different times at one or both of Sites 608 and 610 . For instance, Melonis pompilioides has a FA at $16 \mathrm{Ma}$ according to Schnitker (in press), but this event occurred at 12.6 to $12.7 \mathrm{Ma}$ at Site 608 , and at 4.3 to $5.0 \mathrm{Ma}$ at Site 610 . Many benthic species may migrate slowly (slower than the deep-water circulation rate of the oceans) from one area to another, or from one depth level to another, and thus show timetransgressive first or last appearances. In my opinion many faunal events in deep-sea benthic foraminifers cannot be used for biostratigraphy (especially between sites at different depths or within different basins) without careful evaluation that the events are indeed coeval.

Changes in overall aspect of the benthic foraminiferal fauna can be the result of changes in relative abundances of species, or of the addition of new species (FAs) or the loss of old species (LAs). During the last 25 m.y. there were four periods during which the deep-sea benthic foraminiferal faunas at Sites 608 and 610 changed more than at other times; in addition, there was one additional period of less important, but marked changes at Site 608.
1. 19.2-17 Ma. During this period the relative abundance of Bolivina spp. was high at Site 610 (up to $45 \%$ ) and extremely high at Site 608 (more than 90\%). In my opinion these high relative abundances cannot be fully explained as yet. Similar Bolivina-rich faunas have been found where sediments are rich in organic matter, either because of low oxygen content in the bottom waters as a result of sluggish circulation (e.g., southern California basins [Harman, 1964; Boltovskoy and Wright, 1976] and the Mediterranean sapropels [Cita and Podenzani, 1980; Van der Zwaan, 1980; Mullineaux and Lohmann, 1981]), or because of high productivity in the surface waters on continental slopes (Sen Gupta et al., 1981; Casey et al., 1981; also, see Thomas, in press, for a more detailed discussion).

The high relative abundances of Bolivina spp. in the deep, open northeastern Atlantic might be explained best by postulating that the circulation of the deep waters was sluggish in the early Miocene; the effects of this sluggish circulation might have been aggravated at Site 608 by the rugged topography (see Site 608 report, this volume). The ventilation in the basin probably improved toward the end of the early Miocene, which ended the high relative abundances of Bolivina spp., and brought the benthic $\delta^{13} \mathrm{C}$ values closer to those of the western ba$\sin$ (Miller et al., this volume). The presence of a widespread reflector (R2-Miller and Tucholke, 1983) in the northeastern Atlantic dated as late early Miocene also suggests increased ventilation; at Site 610 this reflector can probably be located just above the level of high $\mathrm{Bo}$ livina abundances (Site 610 report, this volume).

2. 15.5-13.5 Ma. In this period there was an increase in FAs and LAs at both sites, combined with a decrease in relative abundance of Pleurostomella spp. at Site 610, and an increase in Melonis spp. at Site 608. These faunal changes occurred in calcareous nannofossil Zone NN5 (Takayama and Sato, this volume) in the early middle Miocene, at the same time as an increase in benthic foraminiferal $\delta^{18} \mathrm{O}$ values (Miller et al., this volume; Fig. 8). Similar faunal changes have been reported to have occurred at this time by Berggren (1972), Berggren and Schnitker (1983), and Schnitker (in press), but I disagree with the conclusion of these authors that the benthic microfaunas assumed their present-day aspect during the middle Miocene. My data suggest that later faunal changes (see below) were more important than those in the early middle Miocene: of all first and last appearances during the last 25 m.y., only 6 (out of 45 at Site 608,48 at Site 610 ) occurred at this time, and only about $10 \%$ of the total faunas were affected (Thomas, in press).

These faunal changes may have been the result of cooling of the deep waters of the oceans, as a result of increased ice volume on Antarctica, which in its turn may have been caused by the opening of the Drake passage and the thermal isolation of Antarctica (Shackleton and Kennett, 1975). Alternatively, the cool deep waters may have resulted from the sinking of the IcelandFaeroe Ridge (Berggren and Schnitker, 1983; Miller et al., this volume) and the inflow of cold, northern water masses.

3. 10-9 Ma. Several FAs and LAs occurred at Site 608 , and the uniserial lagenids showed a decrease in rel- 


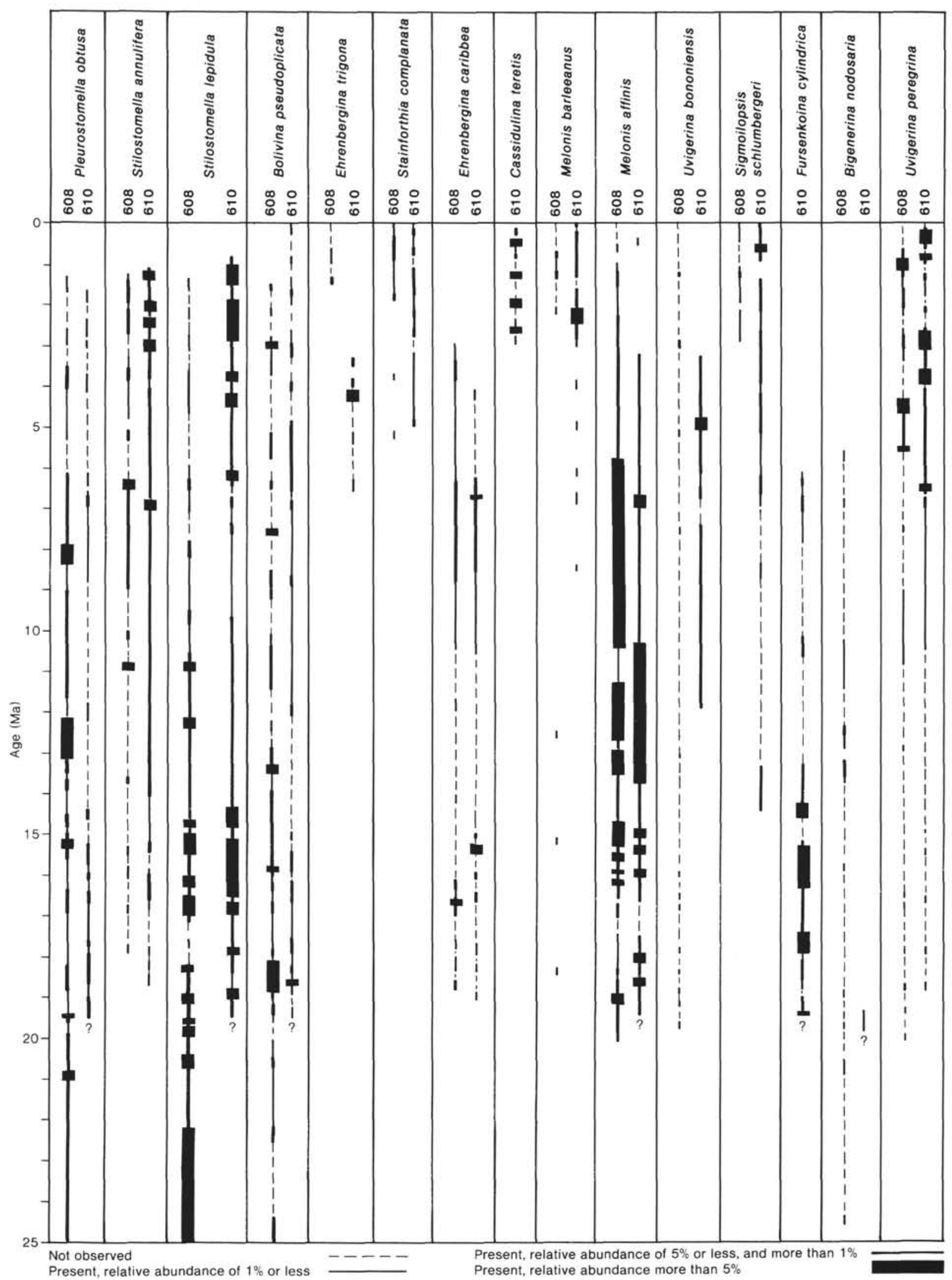

Figure 7. Ranges of selected species that have first and last appearances during the studied interval at Sites 608 and 610 (the lower boundary of recovery at Site 610 is indicated by ?). The age models were constructed using the paleomagnetic data of Clement and Robinson (this volume) with the time scale of Berggren, Kent, and Van Couvering (1985). Ages for the late to middle Miocene at Site 610 are not precise because of spot-coring. 
LATE OLIGOCENE TO RECENT BENTHIC FORAMINIFERS

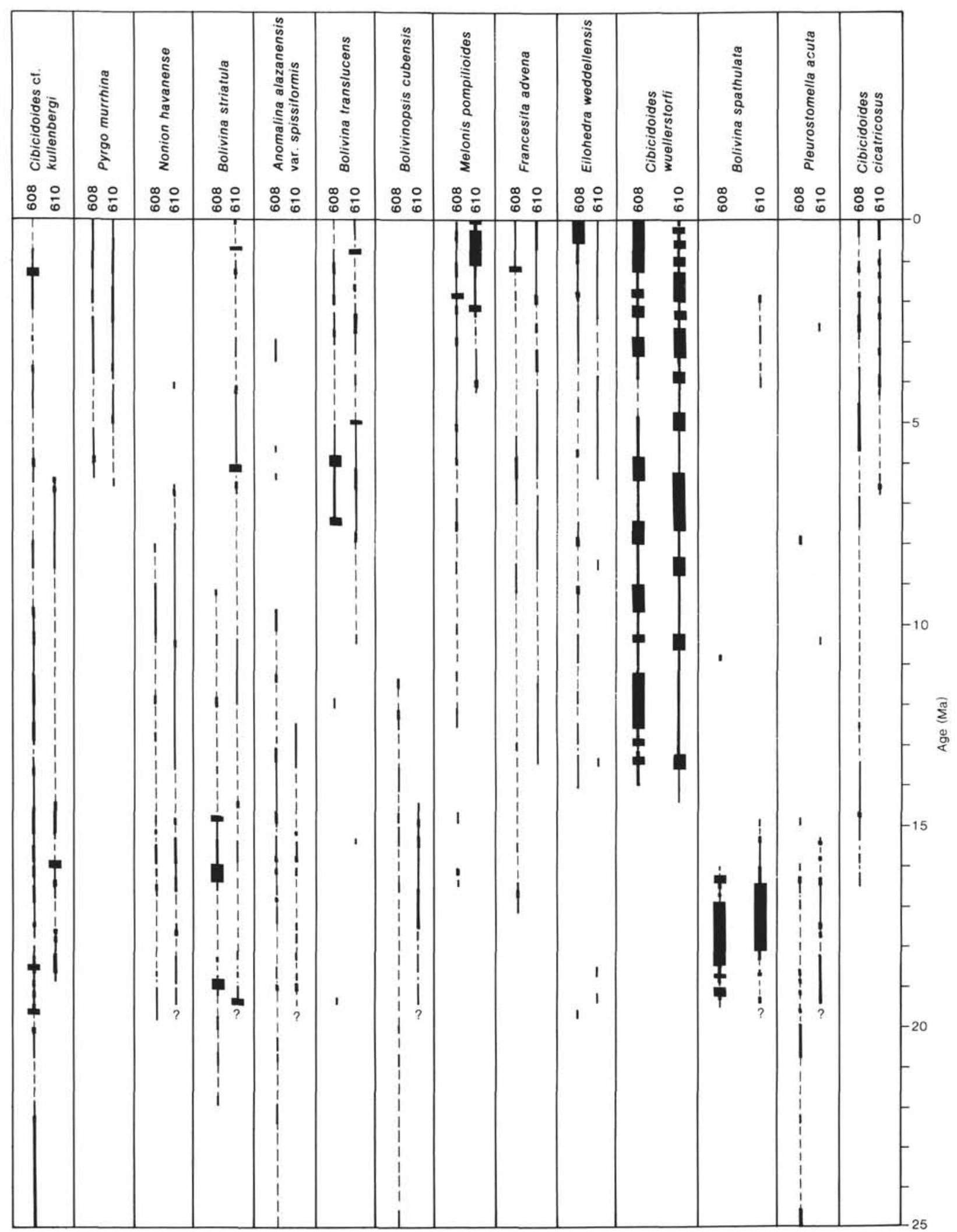

Figure 7 (continued). 

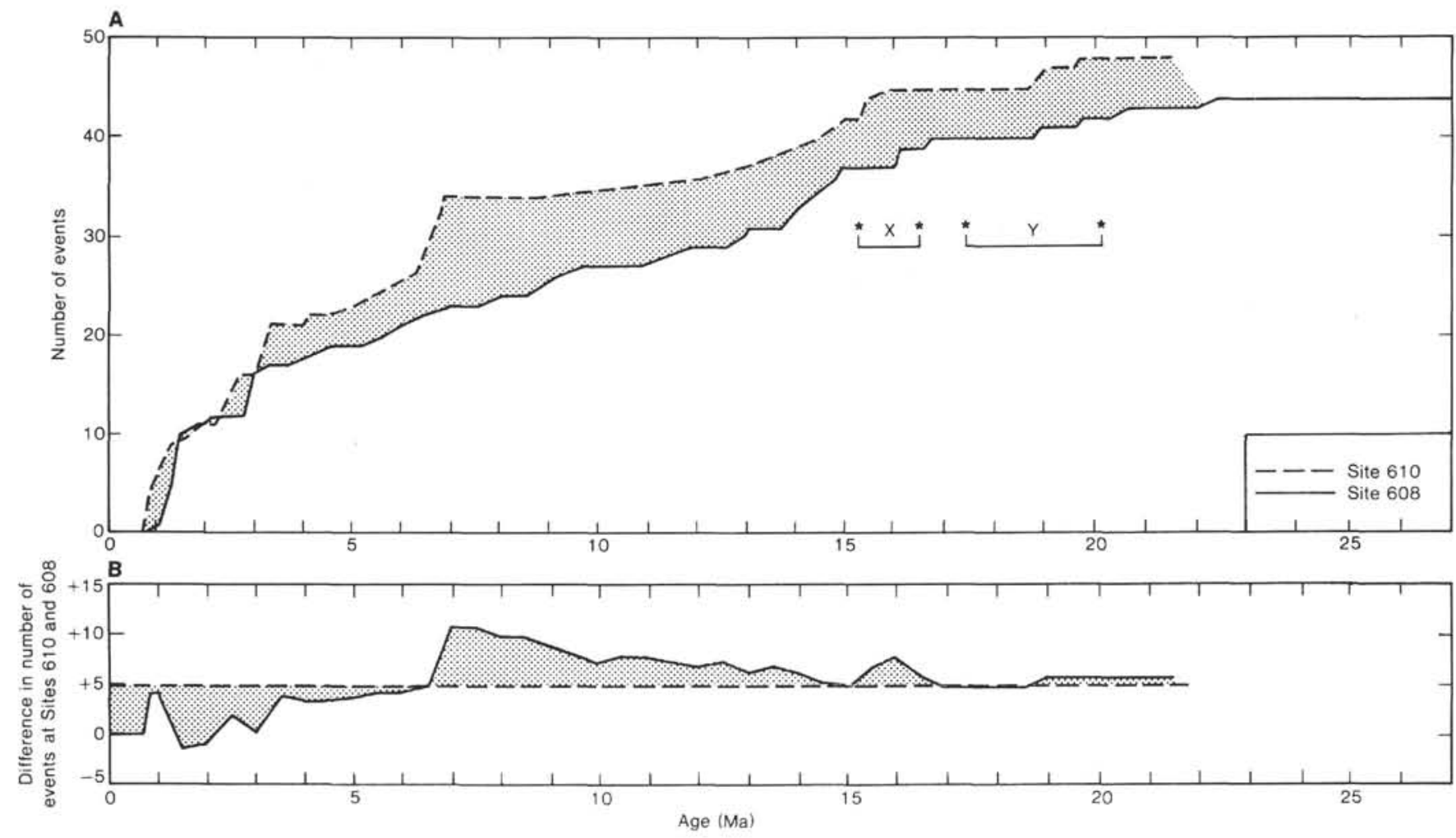

Figure 8. A. Cumulative plot of faunal events (first and last appearances) versus time for Sites 608 and 610 . A steep slope of the curve indicates intervals during which many events occurred. Line marked ${ }^{*} \mathrm{X}^{*}$ indicates the timing of the increase in $\delta^{18} \mathrm{O}$ values, after Miller et al. (this volume). Line marked ${ }^{*} \mathrm{Y}^{*}$ indicates the timing of the increase in $\delta^{13} \mathrm{C}$ values, after Miller et al. (this volume). B. Difference between the cumulative faunal events curves shown in Figure 8A for Sites 608 and 610. Note the increase in the difference between 13.5 and $7 \mathrm{Ma}$.

ative abundance. No obvious changes were observed at Site 610. In many sedimentary sequences (especially in the Rockall Trough area) there is a prominent reflector dated at about $10 \mathrm{Ma}(\mathrm{R} 1-$ Miller and Tucholke, 1983). The presence of this reflector may indicate a more vigorous bottom-water circulation during this period.

4. 7-5.5 Ma. In this period there were 11 FAs and LAs at Site $610(23 \%$ of all faunal events recorded at the site during the last 20 m.y.). At Site 608 there were changes in relative abundance: an increase in miliolids and Nuttallides umbonifera, a decrease in Pleurostomella spp. Stilostomella spp., and Melonis spp. Schnitker (in press) also noted faunal changes at about this time at DSDP sites in the Rockall Plateau area (depths 1600$2700 \mathrm{~m})$, but not in the Bay of Biscay $(4000 \mathrm{~m})$. Murray (this volume), in a quantitative study of benthic foraminiferal faunas from Sites 609 through 611, suggests that changes in watermass structure occurred in the late Miocene. He proposes that Antarctic Bottom Water (AABW) or a similar water mass, which is characterized by the presence of relatively abundant Nuttallides umbonifera (=Osangularia umbonifera in Murray's nomenclature) penetrated far north at this time. This hypothesis is supported by the relatively high relative abundances of $N$. umbonifera between 6.5 and $1.5 \mathrm{Ma}$ at Site 608. Murray's (this volume) hypothesis is also in agreement with that of Blanc and Duplessy (1982), who suggested that the production of North Atlantic Deep Water (NADW) stopped in the latest Miocene, as a result of the Messinian closure of the Mediterranean and the lack of salty
Mediterranean Sea Overflow Water (MSOW); therefore AABW could penetrate further north. This change in deep-water circulation, as suggested by the benthic foraminiferal faunal changes, is most clearly observed in the Rockall Plateau area (this chapter; Schnitker, in press); possibly the faunal changes are related to a change in Norwegian Sea Outflow water in the Rockall Trough (Masson and Kidd, this volume; Reid, 1979). Carbon isotopic evidence presented by Keigwin et al. (this volume), however, suggests no change in production of NADW in the late Miocene.

Keigwin et al., (this volume) also present oxygen isotopic data, which they interpret as suggestive of short glacial maxima between 5.5 and $5.0 \mathrm{Ma}$, but not of prolonged glaciation. This is in contrast with earlier theories that invoked the presence of major ice caps on Antarctica in the late Miocene (Shackleton and Kennett, 1975; Cita and Ryan, 1979). Whatever the exact configuration was of bottom waters in the late Miocene, there were major environmental changes, as indicated by a worldwide change in $\delta^{13} \mathrm{C}$ values in the tests of benthic and planktonic foraminifers at about 6.2 Ma (Bender and Keigwin, 1979; Keigwin, 1979; Haq et al., 1980; Vincent et al., 1980; Loutit and Keigwin, 1982; Keigwin et al., this volume). Possibly the late Miocene changes in $\delta^{13} \mathrm{C}$ values were the result of changes in total biomass; these changes might be orbitally forced through low-latitude precipitation, as suggested by Keigwin and Boyle (1985). Evidence from the comparison of benthic foraminiferal faunas as presented in this paper and by Mur- 
ray (this volume) suggests that there was a change in deep-water circulation in the northeastern Atlantic at about the time of the closure of the Mediterranean and the change in carbon isotopic ratios.

5. 3.5-0.7 Ma. Many FAs and LAs occurred at Sites 608 and 610 during this period (Figs. 8, 9), as well as changes in relative abundances; the long-established taxa of Pleurostomella and Stilostomella disappeared, and cold-water species (e.g., Cassidulina teretis) appeared.

During this interval the glaciation of the Northern Hemisphere started, but the exact timing is still being discussed. McDougall and Wensink (1966) documented glaciation on Iceland at about 3.1 Ma. Shackleton et al. (1984) concluded that ice rafting started at about $2.5 \mathrm{Ma}$ at Site 552 (Rockall Plateau area) and that oxygen isotopic evidence also suggested growth of ice sheets at that time. Data from Leg 94 (Raymo et al., this volume; Ruddiman et al., this volume) indicate that the isotopic evidence for the initiation of glaciation is not clear-cut, and that some environmental changes may have occurred between 3.1 and $2.4 \mathrm{Ma}$ (see also Ruddiman et al., this volume).

Evidence from benthic foraminifers as presented in this chapter was not collected with a sampling density sufficient to resolve glacial-interglacial fluctuations at a time scale dictated by orbital parameters (Ruddiman and McIntyre, 1976, Ruddiman and McIntyre, 1984), but the data can give information on the overall faunal changes associated with the initiation of glaciation. The distribution of faunal events during the period from 3.5 to $0.7 \mathrm{Ma}$ is bimodal at both sites (Fig. 9), with peaks from 1.5 to $1.1 \mathrm{Ma}$ and 3.0 to $2.5 \mathrm{Ma}$ at Site 608 , and somewhat broader peaks (1.3-0.7 Ma and 3.3-2.4 Ma) at Site 610. This suggests that changes in bottom water, which may have been associated with the onset of glaciation, were first felt by benthic foraminifers at Sites 608 and 610 at about $3 \mathrm{Ma}$, possibly somewhat earlier at the shallower site. Then the faunas stabilized, but suffered many LAs of taxa between 1.5 and $0.7 \mathrm{Ma}$ : the decrease in relative abundance of Nuttallides umbonifera at Site 608 at 1.5 Ma might indicate a retreat of an AABW-like bottom-water mass from the site. The benthic faunas do not show many changes at about $2.5 \mathrm{Ma}$, when ice rafting started at the Leg 94 sites, and when there were major changes in the planktonic foraminiferal faunas (Raymo et al., this volume).

\section{CONCLUSIONS}

1. Major changes in the composition of deep-sea benthic foraminiferal faunas at Sites 608 and 610 (northeastern North Atlantic) occurred in the early Miocene (19-17.2 Ma), middle Miocene (15.5-13.5 Ma), late Miocene (7-5.5 Ma), and Pliocene-Pleistocene (3.5-0.7 Ma). The changes during the first period may have resulted from sluggish circulation, during the second from cooling of the deep waters, during the third from changes in deep-water circulation resulting from the closure of the Mediterranean, and during the last period from changes in deep-water circulation as a result of the onset and intensification of Northern Hemisphere glaciation.

2. The last period of faunal changes was the most important, as is evident from the large number of last and a few first appearances, and many changes in relative abundances. The second most important period was the late Miocene, followed by the middle Miocene. Faunal changes in the early Miocene consisted of a temporary dramatic increase in Bolivina spp., and did not involve many irreversible changes (first or last appearances).

3. The patterns of faunal changes are similar at the two sites (e.g., decrease in relative abundance of Pleurostomella spp. and Stilostomella spp.), but the timing of specific first and last appearances is usually different at the two sites. Faunal events in deep-sea benthic foraminiferal faunas can be used for biostratigraphy after careful scrutiny only.

\section{ACKNOWLEDGMENTS}

I thank the shipboard scientic party and the DSDP technicians on Leg 94 for making this leg so successful, and Joop Varekamp and Drew Carey at Wesleyan University, Middletown, Connecticut for the use of facilities. John Murray, Detmar Schnitker, Dave Scott, and Esteban Boltovskoy are thanked for reviewing the paper. This research was partially funded by NSF grant OCE-83-10518.

\section{REFERENCES}

Bender, M. L., and Keigwin, L. D., 1979. Speculations about the upper Miocene change in abyssal Pacific biocarbonate delta ${ }^{13}-\mathrm{C}$. Earth Planet. Sci. Lett., 45:383-393.

Berggren, W. A., 1972. Cenozoic biostratigraphy and paleobiogeography of the North Atlantic. In Laughton, A. S., Berggren, W. A., et al., Init. Repts. DSDP, 12:Washington (U.S. Govt. Printing Office), 965-1002.

Berggren, W. A., Kent, D. V., and Flynn, J. J., 1985. Paleogene geochronology and chronostratigraphy. In Snelling, N. J. (Ed.), The Chronology of the Geological Record, Geol. Soc. London Mem., 10:141-186.

Berggren, W. A., Kent, D. V., and Van Couvering, J., 1985. Neogene geochronology and chronostratigraphy. In Snelling, N. J. (Ed.), The Chronology of the Geological Record, Geol. Soc. London Mem., 10:211-260.

Berggren, W. A., and Schnitker, D., 1983. Cenozoic marine environments in the North Atlantic and Norwegian Sea. In Bott, M. H. P., Saxov, S., Talwani, M., and Thiede, J. (Eds.), Structure and Development of the Greenland-Scotland Ridge: New York (Plenum Press), pp. 495-548.

Blanc, P.-L., and Duplessy, J.-C., 1982. The deep-water circulation during the Neogene and the impact of the Messinian salinity crisis. Deep-Sea Res., 29(12A):1391-1414.

Boltovskoy, E., 1980a. Benthonic foraminifera of the bathyal zone from Oligocene through Quaternary. Rev. Espanola Micropaleontol., 12: 283-304.

$1980 \mathrm{~b}$. On the benthonic bathyal zone foraminifera as stratigraphic guide fossils. J. Foraminif. Res., 10:163-172.

, in press. Quaternary benthic foraminiferal species in the older Cenozoic deposits of the bathyal zone of the world ocean. Micropaleonotology.

Boltovskoy, E., and Wright, R., 1976. Recent Foraminifera: The Hague (W. Junk).

Brady, H. B., 1884. Reports of the Scientific Results of the Exploration Voyage of HMS Challenger, Zoology, (Vol. 9): Report on the Foraminifera Dredged by HMS Challenger During the Years 18731876 (London Royal Society).

Casey, R., Hueni, C., and Leavenly, A., 1981. Brizalina lowmani, meroplankton foraminiferan useful as an indicator of shelfal circulation and eutrophication (with comments on biostratigraphy and evolution). Trans. Gulf Coast Assoc. Geol. Soc., 31:249-255.

Cita, M. B., and Podenzani, M., 1980. Destructive effects of oxygen starvation and ash falls on benthic life: a pilot study. Quat. Res., 13:230-241.

Cita, M. B., and Ryan, W. B. F., 1979. Late Neogene environmental evolution. In von Rad, U., Ryan, W. B. F., et al., Init. Repts. DSDP, 47, Pt. 1: Washington (U.S. Govt. Printing Office), 447-459.

Cushman, J. A., 1923. The Foraminifera of the North Atlantic Ocean. Bull. U.S. Nat. Museum, 104(nos. 1-4)(1918-1923). 


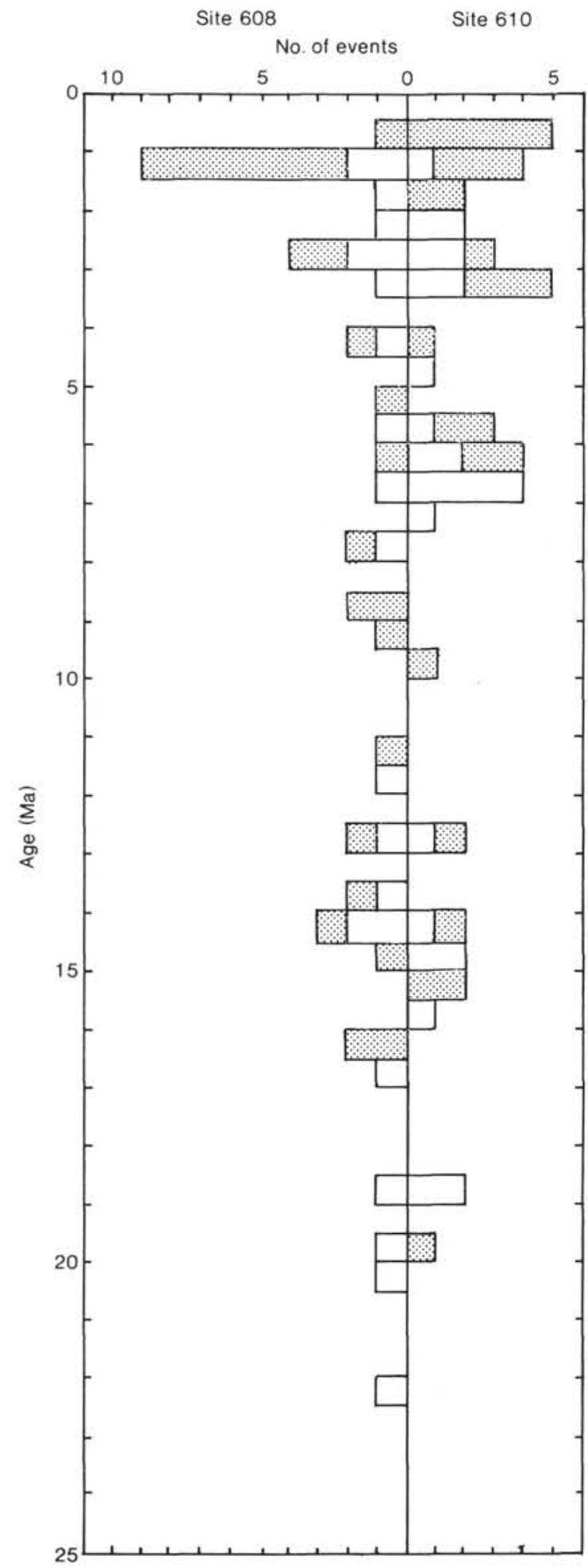

Figure 9. Histogram of first and last appearances at Sites 608 and 610. The first appearances are shown as blank bars, the last appearances as stippled bars. 
Douglas, R., and Woodruff, F., 1981. Deep sea benthic foraminifera. In Emiliani, C. (Ed.), The Oceanic Lithosphere: The Sea (Vol. 7): New York (Wiley Interscience), 1233-1327.

Haq, B. U., Worsley, T. R., Burckle, L. M., Douglas, R. G., Keigwin, L. D., Jr., Opdyke, N. D., Savin, S. M., Sommer, M. A., Vincent, E., and Woodruff, F., 1980. Late Miocene marine carbon isotopic shift and synchroneity of some phytoplanktonic biostratigraphic events. Geology, 8:427-431.

Harman, R. A., 1964. Distribution of foraminifera in the Santa Barbara Basin. Micropaleonotology, 10:81-96.

Keigwin, L. D., 1979. Late Cenozoic stable isotope stratigraphy and paleoceanography of DSDP sites from the east equatorial and central Pacific Ocean. Earth Planet. Sci. Lett., 45:361-382.

Keigwin, L. D., and Boyle, E. A., 1985. Carbon isotopes in deep-sea benthic foraminifera: precession and changes in low latitude biomass. In Sundquist, E. T., and Broecker, W. S. (Eds.), The Carbon Cycle and Atmospheric $\mathrm{CO}_{2}$ : Archaean to Present. Am. Geophys. Union Geophys. Monogr., 32:319-328.

Loutit, T. S., and Keigwin, L. D., 1982. Stable isotopic evidence for latest Miocene sea-level fall in the Mediterranean region. Nature, 300:163-166.

McDougall, I., and Wensink, H., 1966. Paleomagnetism and geochronology of the Pliocene-Pleistocene lavas in Iceland. Earth Planet. Sci. Lett., 1:232-245.

Miller, K. G., 1983. Eocene-Oligocene paleoceanography of the deep Bay of Biscay: benthic foraminiferal evidence. Mar. Micropaleontol., 7:403-440.

Miller, K. G., Aubry, M.-P., Kahn, M. J., Melillo, A. L., Kent, D. V., and Berggren, W. A., 1985. Oligocene-Miocene biostratigraphy, magnetostratigraphy and isotopic stratigraphy of the western North Atlantic. Geology, 13:257-261.

Miller, K. G., and Tucholke, B. E., 1983. Development of abyssal circulation south of the Greenland-Scotland Ridge. In Bott, M. H. P., Saxov, S., Talwani, M., and Thiede, J. (Eds.), Structure and Development of the Greenland-Scotland Ridge: New York (Plenum Press), pp. 549-589.

Mullineaux, L. S., and Lohmann, G. P., 1981. Late Quaternary stagnation and recirculation of the eastern Mediterranean: changes in the deep water recorded by fossil benthic foraminifera. J. Foraminif. Res., 11:20-39.

Murray, J. W., 1984. Paleogene and Neogene benthic foraminifera from Rockall Plateau. In Roberts, D. G., Schnitker, D., et al., Init. Repts. DSDP, 81: Washington (U.S. Govt. Printing Office), 503-534.

Phleger, F. B., Parker, F. L., and Peirson, J. F., 1953. Reports of the Swedish Deep Sea Expedition (Vol. 7): North Atlantic Foraminifera. Sediment Cores from North Atlantic Ocean, No. 1.

Pisias, N. G., Shackleton, N. J., and Hall, M. A., 1985. Stable isotope and calcium carbonate records from HPC Site 574: high resolution records from the middle Miocene. In Mayer, L. A., Theyer, F., et al., Init. Repts. DSDP, 85: Washington (U.S. Govt. Printing Office), 735-748.

Reid, J. L., 1979. On the contribution of Mediterranean Sea outflow to the Norwegian-Greenland Sea. Deep-Sea Res., 26A:1194-1223.

Ruddiman, W. F., and McIntyre, A., 1976. North Atlantic paleoclimatic changes over the past 600,000 years. Mem. Geol. Soc. Am., 145:111-146.

1984. Ice-age thermal response and climatic role of the surface Atlantic Ocean. Bull. Geol. Soc. Am., 95:381-396.

Savin, S. M., Douglas, R. G., Keller, G., Killingley, J. S., Shaughnessy, L., Sommer, M. A., Vincent, E., and Woodruff, F., 1981. Miocene benthic foraminiferal isotope records: a synthesis. Mar. Micropaleontol., 6:423-450.

Schnitker, D., 1974. West Atlantic abyssal circulation during the past 120,000 years. Nature, 248:385-387.

1979. Cenozoic deep water benthic foraminifers, Bay of Biscay. In Montadert, L., Roberts, D. G., et al., Init. Repts. DSDP, 48: Washington (U.S. Govt. Printing Office), 377-414.

1980. Quaternary deep-sea benthic foraminifers and bottom waters. Annual Rev Earth Planet. Sci., 8:343-370.
1982. Climatic variability and deep ocean circulation: evidence from the North Atlantic. Palaeogeogr. Palaeoclimat. Palaeoecol., 40:213-234.

1984. High resolution of benthic foraminifers in the late Neogene of the northeastern North Atlantic. In Roberts, D. G., Schnitker, D., et al., Init. Repts. DSDP, 81: Washington (U.S. Govt. Printing Office), 611-622.

, in press. Northeast Atlantic Neogene benthic foraminiferal faunas: tracers of deep water paleoceanography. In Summerhayes, C., and Shackleton, N. J. (Eds.), North Atlantic Palaeoceanography. J. Geol. Soc. London Spec. Pap.

Sen Gupta, B. K., Lee, R. F., and May, M. S., 1981. Upwelling and unusual assemblages of benthic foraminifera on the northern Florida continental slope. J. Paleontol., 55:853-857.

Shackleton, N. J., Backman, J., Zimmerman, H., Kent, D. V., Hall, M. A., Roberts, D. G., Schnitker, D., Baldauf, J. G., Desprairies, A., Homrighausen, H., Huddlestun, P., Keene, J. B., Kaltenback, A. J., Krumsiek, K. A. O., Morton, A. C., Murray, J. W., and Westberg-Smith, J., 1984. Oxygen isotope calibration of the onset of ice rafting in the North Atlantic. Nature, 307:620-623.

Shackleton, N. J., and Kennett, J. P., 1975. Paleotemperature history of the Cenozoic and the initiation of Antarctic glaciation: oxygen and carbon isotope analysis in DSDP Sites 277,279 , and 281. In Kennett, J. P., Houtz, R. E., et al., Init. Repts. DSDP, 29: Washington (U.S. Govt. Printing Office), 743-755.

Streeter, S. S., 1973. Bottom water and benthonic foraminifera in the North Atlantic: glacial-interglacial contrasts. Quat. Res., 3:131141.

Streeter, S. S., and Shackleton, N. J., 1979. Paleo-circulation of the deep North Atlantic: 150,000 year record of benthic foraminifera and oxygen-18. Science, 203:163-171.

Thomas, E., 1985. Late Eocene to Recent deep sea benthic foraminifera from the central equatorial Pacific Ocean. In Mayer, L. A., Theyer, F., et al., Init. Repts. DSDP, 85: Washington (U.S. Govt. Printing Office), 655-694.

1986. Changes in composition of Neogene benthic foraminiferal faunas in equatorial Pacific and North Atlantic. Palaeogeogr., Palaeoclimat., Paleoecol., 53:47-61.

in press. Early to middle Miocene benthic foraminiferal faunas from DSDP Sites 608 and 610, North Atlantic Ocean. In Summerhayes, C., and Shackleton, N. J. (Eds.), North Atlantic Palaeoceanography. J. Geol. Soc. London Spec. Pap.

Van der Zwaan, G. J., 1980. The impact of climatic changes on deep sea benthos. Proc. Kon. Nederlandse Akad. Wetenschappen, Ser. $B, 83: 379-397$.

Vincent, E., and Killingley, J. S., 1985. Oxygen and carbon isotopic record for the early and middle Miocene in the central equatoria Pacific. In Mayer, L. A., Theyer, F., et al., Init. Repts. DSDP, 85: Washington (U.S. Govt. Printing Office), 749-770.

Vincent, E., Killingley, J. S., and Berger, W. H., 1980. The magnetic Epoch 6 carbon shift: a change in the ocean's $13 \mathrm{C} / 12 \mathrm{C}$ ratio 6.2 m.y. ago. Mar. Micropaleontol., 5:185-203.

1985. Miocene oxygen and carbon isotope stratigraphy of the tropical Indian Ocean. In Kennett, J. P.(Ed.), The Miocene Ocean: Paleoceanography and Biogeography. Mem. Geol. Soc. Am., 163:103-132.

Woodruff, F., 1985. Changes in Miocene deep-sea benthic foraminiferal distribution in the Pacific Ocean: relationship to paleoceanog raphy. In Kennett, J. P. (Ed.), The Miocene Ocean; Paleoceanography and Biogeography. Mem. Geol. Soc. Am., 163:131-176.

Woodruff, F., and Douglas, R. G., 1981. Response of deep sea benthic foraminifera to Miocene paleoclimatic events, DSDP Site 289. Mar. Micropaleontol., 6:617-632.

Woodruff, F., Savin, S. M., and Douglas, R. G., 1979. Miocene stable isotope record: a detailed deep Pacific study and its paleoclimatic implications. Earth Planet. Sci. Lett., 45:383-393.

Date of Initial Receipt: 6 June 1985

Date of Acceptance: 3 December 1985 
APPENDIX A

Counts of Benthic Foraminifers (Tables 1 and 2)

Table 1. Counts of benthic foraminifers in Site 608 samples.

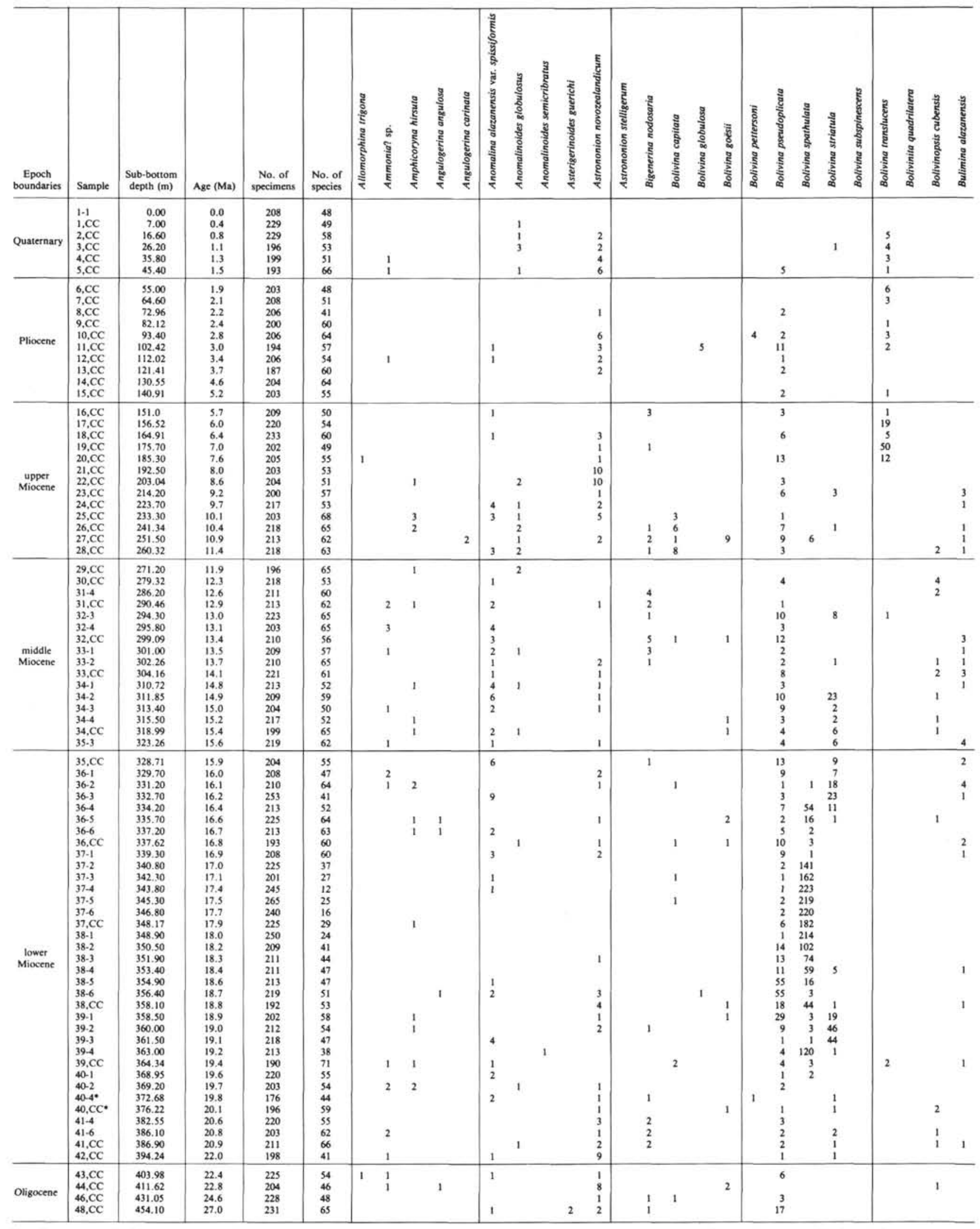

Note: Ages are extrapolated from the paleomagnetic data in Clement and Robinson (this volume). Samples with an asterisk (*) did not contain sufficient specimens and were not used in the analysis. 
Table 1 (continued).

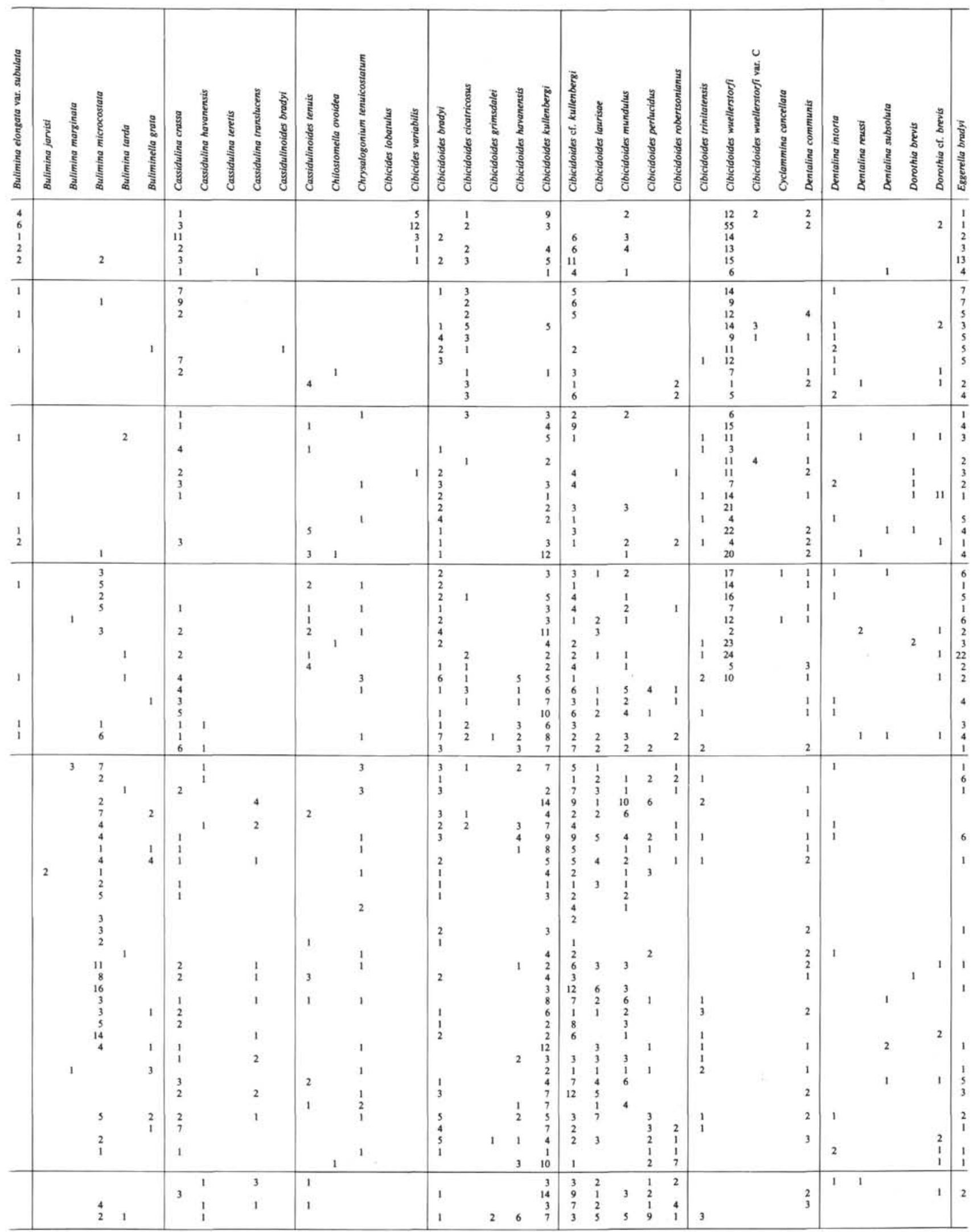


Table 1 (continued).

\begin{tabular}{|c|c|c|c|c|c|c|c|c|c|c|c|c|c|c|c|c|c|c|c|c|c|c|c|c|}
\hline $\begin{array}{c}\begin{array}{c}\text { Epoch } \\
\text { boundaries }\end{array} \\
\text {. }\end{array}$ & Sample & $\begin{array}{l}\text { Sub-bottom } \\
\text { depth (m) }\end{array}$ & $\mathrm{Age}(\mathrm{Ma})$ & $\begin{array}{c}\text { No. of } \\
\text { specimens }\end{array}$ & $\begin{array}{l}\text { No. of } \\
\text { species }\end{array}$ & है & 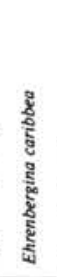 & 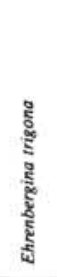 & 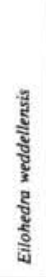 & 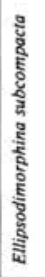 & 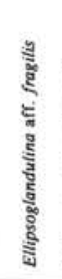 & 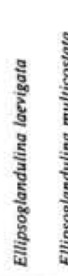 & 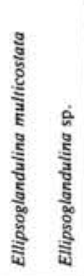 & 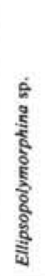 & 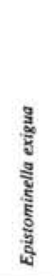 & 赔 & 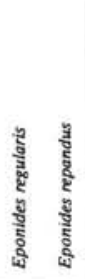 & 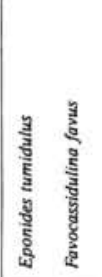 & $\begin{array}{l}\text { हूँ } \\
\text { कू } \\
\text { हूँ } \\
\text { है } \\
\text { है }\end{array}$ & 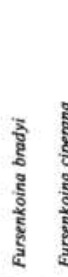 & 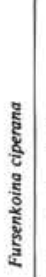 & 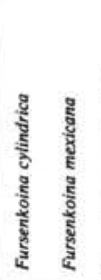 & 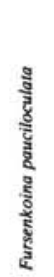 & 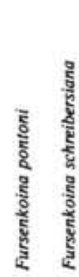 \\
\hline Quaternary & $\begin{array}{l}1,1 \\
1, \mathrm{CC} \\
2, \mathrm{CC} \\
3, \mathrm{CC} \\
4, \mathrm{CC} \\
3, \mathrm{CC}\end{array}$ & $\begin{array}{r}0.00 \\
7.00 \\
16.60 \\
26.20 \\
35.80 \\
45.40 \\
\end{array}$ & $\begin{array}{l}0.0 \\
0.4 \\
0.8 \\
1.1 \\
1.3 \\
1.5 \\
1.5\end{array}$ & $\begin{array}{l}208 \\
229 \\
229 \\
196 \\
199 \\
193\end{array}$ & $\begin{array}{l}48 \\
49 \\
58 \\
53 \\
51 \\
66\end{array}$ & 1 & & $\begin{array}{l}2 \\
4\end{array}$ & $\begin{array}{r}25 \\
16 \\
6 \\
3 \\
2 \\
1\end{array}$ & 1 & & & & & $\begin{array}{r}50 \\
16 \\
20 \\
16 \\
10 \\
4\end{array}$ & & $\begin{array}{l}1 \\
3 \\
1\end{array}$ & $\begin{array}{ll}6 & \\
3 & \\
2 & \\
& \\
& 1\end{array}$ & $\begin{array}{c}5 \\
1 \\
3 \\
1 \\
14\end{array}$ & $\begin{array}{l}1 \\
1 \\
1\end{array}$ & & & 1 & 1 \\
\hline Pliocene & $\begin{array}{l}6, \mathrm{CC} \\
7, \mathrm{CC} \\
8, \mathrm{CC} \\
9, \mathrm{CC} \\
10, \mathrm{CC} \\
11, \mathrm{CC} \\
12, \mathrm{CC} \\
13, \mathrm{CC} \\
14, \mathrm{CC} \\
15, \mathrm{CC}\end{array}$ & $\begin{array}{r}55.00 \\
64.60 \\
72.96 \\
82.12 \\
93.40 \\
102.42 \\
112.02 \\
121.41 \\
130.55 \\
140.91\end{array}$ & $\begin{array}{l}1.9 \\
2.1 \\
2.2 \\
2.4 \\
2.8 \\
3.0 \\
3.4 \\
3.7 \\
4.6 \\
5.2\end{array}$ & $\begin{array}{l}203 \\
208 \\
206 \\
200 \\
206 \\
194 \\
206 \\
187 \\
204 \\
203\end{array}$ & $\begin{array}{l}48 \\
51 \\
41 \\
60 \\
64 \\
57 \\
54 \\
60 \\
64 \\
55\end{array}$ & & $\begin{array}{l}1 \\
6 \\
4 \\
1 \\
2\end{array}$ & & $\begin{array}{l}3 \\
2 \\
1 \\
1 \\
1 \\
1 \\
1\end{array}$ & 4 & 1 & & & & $\begin{array}{r}11 \\
11 \\
13 \\
7 \\
8 \\
18 \\
13 \\
11 \\
5 \\
6\end{array}$ & & & 1 & 1 & $\begin{array}{l}1 \\
1 \\
2\end{array}$ & & & $\begin{array}{l}1 \\
1 \\
1\end{array}$ & \\
\hline $\begin{array}{c}\text { upper } \\
\text { Miocene }\end{array}$ & $\begin{array}{l}16, \mathrm{CC} \\
17, \mathrm{CC} \\
18, \mathrm{CC} \\
19, \mathrm{CC} \\
20, \mathrm{CC} \\
21, \mathrm{CC} \\
22, \mathrm{CC} \\
23, \mathrm{CC} \\
24, \mathrm{CC} \\
25, \mathrm{CC} \\
26, \mathrm{CC} \\
27, \mathrm{CC} \\
28, \mathrm{CC}\end{array}$ & $\begin{array}{l}151.0 \\
155.52 \\
164.91 \\
175.70 \\
185.30 \\
192.50 \\
203.04 \\
214.20 \\
223.70 \\
233.30 \\
241.34 \\
251.50 \\
260.32\end{array}$ & $\begin{array}{c}5.7 \\
6.0 \\
6.4 \\
7.0 \\
7.6 \\
8.0 \\
8.6 \\
9.2 \\
9.7 \\
10.1 \\
10.4 \\
10.9 \\
11.4\end{array}$ & $\begin{array}{l}209 \\
220 \\
233 \\
202 \\
205 \\
203 \\
204 \\
200 \\
217 \\
203 \\
218 \\
213 \\
218\end{array}$ & $\begin{array}{l}50 \\
54 \\
60 \\
49 \\
55 \\
53 \\
51 \\
57 \\
53 \\
68 \\
65 \\
62 \\
63\end{array}$ & & $\begin{array}{r}1 \\
1 \\
10 \\
3 \\
3 \\
2 \\
3 \\
1 \\
1 \\
1 \\
1\end{array}$ & & $\begin{array}{l}1 \\
4 \\
3 \\
1 \\
1\end{array}$ & 1 & 1 & & & & $\begin{array}{r}23 \\
8 \\
12 \\
13 \\
9 \\
4 \\
3 \\
11 \\
5 \\
8 \\
4 \\
9 \\
9\end{array}$ & 3 & 2 & & $\begin{array}{l}1 \\
3 \\
5 \\
1 \\
1 \\
1 \\
1\end{array}$ & $\begin{array}{l}2 \\
1\end{array}$ & & & 1 & \\
\hline $\begin{array}{l}\text { middle } \\
\text { Miocene }\end{array}$ & $\begin{array}{l}29, \mathrm{CC} \\
30, \mathrm{CC} \\
31 \cdot 4 \\
31, \mathrm{CC} \\
32-3 \\
32-4 \\
32, \mathrm{CC} \\
33-1 \\
33-2 \\
33, \mathrm{CC} \\
34-1 \\
34-2 \\
34-3 \\
34-4 \\
34, \mathrm{CC} \\
35-3\end{array}$ & $\begin{array}{l}271.20 \\
279.32 \\
286.20 \\
299.46 \\
294.30 \\
295.80 \\
299.09 \\
301.00 \\
302.26 \\
304.16 \\
310.72 \\
311.85 \\
313.40 \\
315.50 \\
318.99 \\
323.26\end{array}$ & $\begin{array}{l}11.9 \\
12.3 \\
12.6 \\
12.9 \\
13.0 \\
13.1 \\
13.4 \\
13.5 \\
13.7 \\
14.1 \\
14.8 \\
14.9 \\
15.0 \\
15.2 \\
15.4 \\
15.6\end{array}$ & $\begin{array}{l}196 \\
218 \\
211 \\
213 \\
223 \\
203 \\
210 \\
209 \\
210 \\
221 \\
213 \\
209 \\
204 \\
217 \\
199 \\
219\end{array}$ & $\begin{array}{l}65 \\
53 \\
60 \\
62 \\
65 \\
65 \\
56 \\
57 \\
65 \\
61 \\
52 \\
59 \\
50 \\
52 \\
65 \\
62\end{array}$ & & 1 & & $\begin{array}{l}1 \\
1 \\
1 \\
2 \\
1\end{array}$ & 1 & & & & & $\begin{array}{c}1 \\
6 \\
4 \\
15 \\
14 \\
3 \\
8 \\
12 \\
9 \\
8 \\
11 \\
9 \\
2 \\
2 \\
6 \\
5 \\
13\end{array}$ & 1 & 1 & & 2 & $\begin{array}{l}1 \\
1 \\
1\end{array}$ & 1 & 1 & & \\
\hline $\begin{array}{l}\text { lower } \\
\text { Miocene }\end{array}$ & 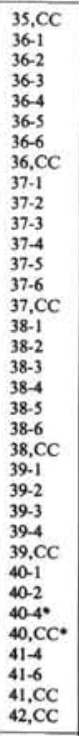 & 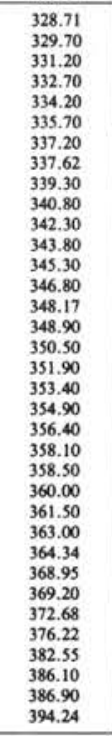 & $\begin{array}{l}15.9 \\
16.0 \\
16.1 \\
16.2 \\
16.4 \\
16.6 \\
16.7 \\
116.8 \\
16.9 \\
17.0 \\
17.1 \\
177.4 \\
17.5 \\
17.7 \\
17.9 \\
18.0 \\
18.2 \\
18.3 \\
18.4 \\
18.6 \\
18.7 \\
18.8 \\
18.9 \\
19.0 \\
19.1 \\
19.2 \\
19.4 \\
19.6 \\
19.7 \\
19.8 \\
20.1 \\
220.6 \\
20.8 \\
20.9 \\
22.0 \\
\end{array}$ & $\begin{array}{l}204 \\
208 \\
210 \\
253 \\
213 \\
225 \\
213 \\
193 \\
208 \\
225 \\
201 \\
245 \\
265 \\
240 \\
225 \\
250 \\
209 \\
211 \\
211 \\
213 \\
219 \\
192 \\
202 \\
212 \\
218 \\
213 \\
190 \\
220 \\
203 \\
176 \\
196 \\
220 \\
203 \\
211 \\
198 \\
\end{array}$ & $\begin{array}{l}55 \\
55 \\
47 \\
64 \\
41 \\
52 \\
64 \\
63 \\
60 \\
60 \\
37 \\
27 \\
12 \\
25 \\
16 \\
29 \\
24 \\
41 \\
44 \\
47 \\
47 \\
51 \\
53 \\
58 \\
54 \\
47 \\
38 \\
71 \\
55 \\
54 \\
44 \\
59 \\
55 \\
62 \\
66 \\
41 \\
\end{array}$ & 1 & $\begin{array}{r}10 \\
1 \\
11 \\
9 \\
8\end{array}$ & 4 & 2 & $\begin{array}{l}1 \\
1 \\
1\end{array}$ & 1 & & 1 & & $\begin{array}{r}1 \\
5 \\
7 \\
7 \\
9 \\
4 \\
2 \\
3 \\
11 \\
4 \\
7 \\
9 \\
20 \\
4 \\
15 \\
5 \\
23 \\
11 \\
8 \\
10\end{array}$ & & 1 & & $\begin{array}{l}1 \\
5 \\
1 \\
1\end{array}$ & ${ }^{4}$ & $\begin{array}{l}1 \\
1 \\
1 \\
1 \\
2\end{array}$ & & 2 & \\
\hline Oligocene & $\begin{array}{l}43, \mathrm{CC} \\
44, \mathrm{CC} \\
46, \mathrm{CC} \\
48, \mathrm{CC}\end{array}$ & $\begin{array}{l}403.98 \\
411.62 \\
431.05 \\
454.10\end{array}$ & $\begin{array}{l}22.4 \\
22.8 \\
24.6 \\
27.0\end{array}$ & $\begin{array}{l}225 \\
204 \\
228 \\
231\end{array}$ & $\begin{array}{l}54 \\
46 \\
48 \\
65\end{array}$ & & & & 2 & $\begin{array}{l}1 \\
1 \\
2\end{array}$ & 2 & 1 & & & $\begin{array}{l}2 \\
2\end{array}$ & 1 & & & & 10 & & 1 & 2 & \\
\hline
\end{tabular}


Table 1 (continued).

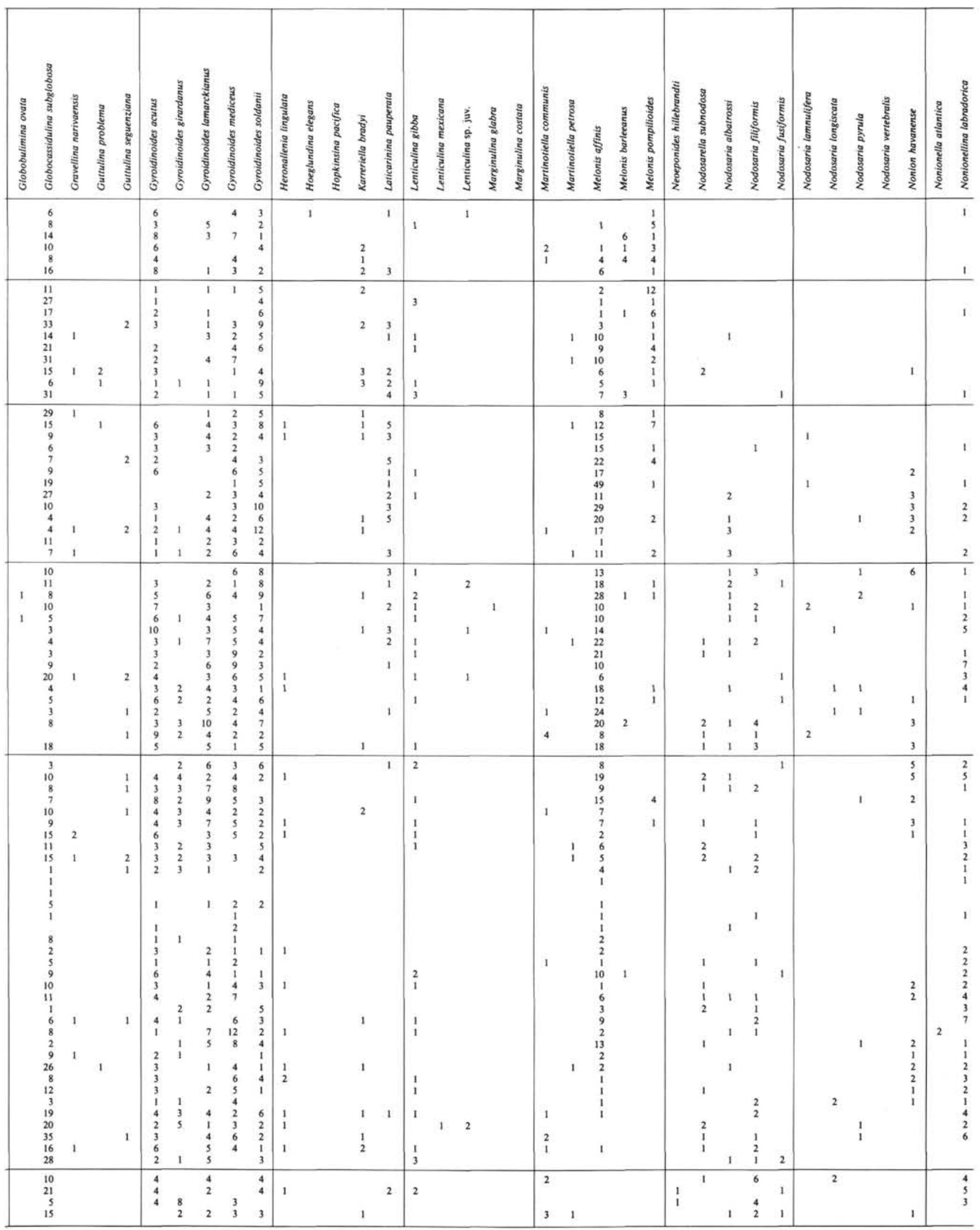


Table 1 (continued).

\begin{tabular}{|c|c|c|c|c|c|c|c|c|c|c|c|c|c|c|c|c|c|c|c|c|c|c|c|c|c|c|c|}
\hline $\begin{array}{c}\text { Epoch } \\
\text { boundaries }\end{array}$ & Sample & $\begin{array}{l}\text { Sub-bottom } \\
\text { depth (m) }\end{array}$ & Age (Ma) & $\begin{array}{l}\text { No. of } \\
\text { specimens }\end{array}$ & $\begin{array}{l}\text { No. of } \\
\text { species }\end{array}$ & 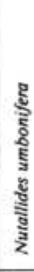 & 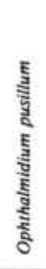 & 这 & 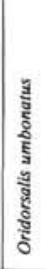 & 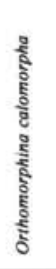 & 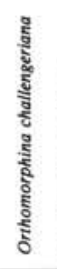 & 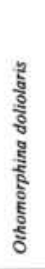 & 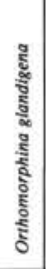 & 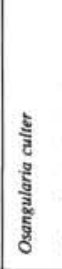 & 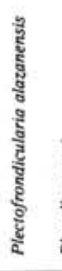 & $\begin{array}{l}\frac{\pi}{2} \\
\frac{5}{2} \\
\frac{5}{2} \\
\frac{5}{2}\end{array}$ & 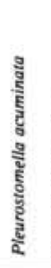 & 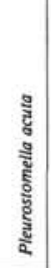 & 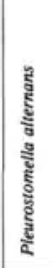 & 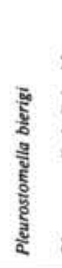 & 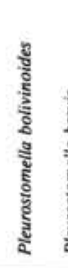 & 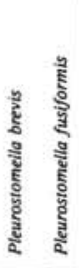 & 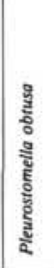 & 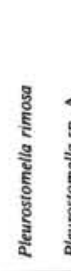 & 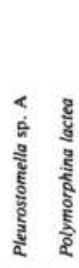 & 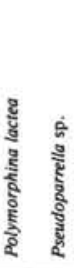 & 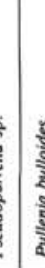 \\
\hline Quaternary & $\begin{array}{l}1,1 \\
1, \mathrm{CC} \\
2, \mathrm{CC} \\
3, \mathrm{CC} \\
4, \mathrm{CC} \\
5, \mathrm{CC}\end{array}$ & $\begin{array}{r}0.00 \\
7.00 \\
16.60 \\
26.20 \\
35.80 \\
45.40 \\
\end{array}$ & $\begin{array}{l}0.0 \\
0.4 \\
0.8 \\
1.1 \\
1.3 \\
1.5\end{array}$ & $\begin{array}{l}208 \\
229 \\
229 \\
196 \\
199 \\
193\end{array}$ & $\begin{array}{l}48 \\
49 \\
58 \\
53 \\
51 \\
66\end{array}$ & 30 & $\begin{array}{l}3 \\
6 \\
3 \\
1 \\
6 \\
1\end{array}$ & $\begin{array}{r}13 \\
9 \\
9 \\
9 \\
4 \\
1\end{array}$ & $\begin{array}{r}3 \\
3 \\
21 \\
25 \\
19 \\
7\end{array}$ & & & 1 & 1 & & & & 1 & & 2 & & 1 & & i & & & & 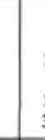 \\
\hline Pliocene & $\begin{array}{l}6, \mathrm{CC} \\
7, \mathrm{CC} \\
8, \mathrm{CC} \\
9, \mathrm{CC} \\
10, \mathrm{CC} \\
11, \mathrm{CC} \\
12, \mathrm{CC} \\
13, \mathrm{CC} \\
14, \mathrm{CC} \\
15, \mathrm{CC}\end{array}$ & $\begin{array}{r}55.00 \\
64.60 \\
72.96 \\
82.12 \\
93.40 \\
102.42 \\
112.02 \\
121.41 \\
130.55 \\
140.91 \\
\end{array}$ & $\begin{array}{l}1.9 \\
2.1 \\
2.2 \\
2.4 \\
2.8 \\
3.0 \\
3.4 \\
3.7 \\
4.6 \\
5.2\end{array}$ & $\begin{array}{l}203 \\
208 \\
206 \\
200 \\
206 \\
194 \\
206 \\
187 \\
204 \\
203\end{array}$ & $\begin{array}{l}48 \\
51 \\
41 \\
60 \\
64 \\
57 \\
54 \\
60 \\
64 \\
55 \\
\end{array}$ & $\begin{array}{r}1 \\
20 \\
47 \\
5 \\
16 \\
1 \\
18 \\
14 \\
10 \\
8\end{array}$ & $\begin{array}{r}8 \\
7 \\
12 \\
2 \\
4 \\
\\
\\
2 \\
1 \\
1\end{array}$ & $\begin{array}{r}19 \\
9 \\
1 \\
1 \\
1 \\
3 \\
5 \\
1 \\
2 \\
4\end{array}$ & $\begin{array}{l}23 \\
25 \\
24 \\
10 \\
24 \\
17 \\
14 \\
5 \\
34 \\
32 \\
32\end{array}$ & $\begin{array}{l}1 \\
2 \\
1\end{array}$ & & 1 & i & & & & $\begin{array}{l}3 \\
4 \\
2 \\
1\end{array}$ & & $\begin{array}{l}1 \\
2 \\
1 \\
1\end{array}$ & . & $\begin{array}{l}1 \\
1 \\
1 \\
1\end{array}$ & & $\begin{array}{l}3 \\
1 \\
1 \\
\end{array}$ & & & & 3 \\
\hline $\begin{array}{l}\text { upper } \\
\text { Miocene }\end{array}$ & $\begin{array}{l}16, \mathrm{CC} \\
17, \mathrm{CC} \\
18, \mathrm{CC} \\
19, \mathrm{CC} \\
20, \mathrm{CC} \\
21, \mathrm{CC} \\
22, \mathrm{CC} \\
23, \mathrm{CC} \\
24, \mathrm{CC} \\
25, \mathrm{CC} \\
26, \mathrm{CC} \\
27, \mathrm{CC} \\
28, \mathrm{CC} \\
\end{array}$ & $\begin{array}{l}151.0 \\
156.52 \\
164.91 \\
175.70 \\
185.30 \\
192.50 \\
203.04 \\
214.20 \\
223.70 \\
2233.30 \\
241.34 \\
251.50 \\
260.32 \\
\end{array}$ & $\begin{array}{r}5.7 \\
6.0 \\
6.4 \\
7.0 \\
7.6 \\
8.0 \\
8.6 \\
9.2 \\
9.7 \\
10.1 \\
10.4 \\
10.9 \\
11.4 \\
\end{array}$ & $\begin{array}{l}209 \\
220 \\
2233 \\
202 \\
205 \\
203 \\
204 \\
200 \\
217 \\
203 \\
218 \\
213 \\
218 \\
\end{array}$ & $\begin{array}{l}50 \\
54 \\
60 \\
49 \\
55 \\
53 \\
51 \\
57 \\
53 \\
68 \\
65 \\
62 \\
63 \\
\end{array}$ & $\begin{array}{r}13 \\
19 \\
17 \\
7 \\
7 \\
7\end{array}$ & $\begin{array}{l}1 \\
1\end{array}$ & $\begin{array}{l}3 \\
5 \\
7 \\
3 \\
1 \\
3 \\
\end{array}$ & $\begin{array}{c}15 \\
9 \\
19 \\
12 \\
13 \\
9 \\
8 \\
16 \\
16 \\
6 \\
18 \\
13 \\
15 \\
\end{array}$ & 2 & & 4 & $\begin{array}{l}3 \\
6 \\
4 \\
\end{array}$ & & & & $\begin{array}{l}2 \\
1 \\
4\end{array}$ & 3 & $\begin{array}{l}1 \\
2 \\
1 \\
1 \\
2\end{array}$ & 1 & $\begin{array}{l}2 \\
3 \\
3 \\
1 \\
2 \\
2 \\
1 \\
3 \\
4 \\
2 \\
\end{array}$ & $\begin{array}{l}2 \\
1 \\
1 \\
1 \\
2 \\
1 \\
1\end{array}$ & $\begin{array}{r}8 \\
4 \\
3 \\
12 \\
2 \\
4 \\
5 \\
9 \\
6 \\
4 \\
5 \\
\end{array}$ & 1 & & 1 & 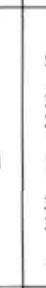 \\
\hline $\begin{array}{l}\text { middle } \\
\text { Miocene }\end{array}$ & $\begin{array}{l}29, \mathrm{CC} \\
30, \mathrm{CC} \\
31-4 \\
31, \mathrm{CC} \\
32-3 \\
32-4 \\
32, \mathrm{CC} \\
333-1 \\
33-2 \\
33, \mathrm{CC} \\
34-1 \\
34-2 \\
34-3 \\
34-4 \\
34, \mathrm{CC} \\
35-3\end{array}$ & $\begin{array}{l}271.20 \\
279.32 \\
286.20 \\
290.46 \\
294.30 \\
295.80 \\
299.09 \\
301.00 \\
302.26 \\
304.16 \\
310.72 \\
311.85 \\
313.40 \\
315.50 \\
318.99 \\
323.26\end{array}$ & $\begin{array}{l}11.9 \\
11.3 \\
12.6 \\
12.9 \\
13.0 \\
13.1 \\
13.4 \\
13.5 \\
13.7 \\
114.1 \\
14.8 \\
14.9 \\
15.0 \\
15.2 \\
15.4 \\
15.6\end{array}$ & $\begin{array}{l}196 \\
218 \\
211 \\
213 \\
223 \\
203 \\
210 \\
209 \\
210 \\
221 \\
211 \\
209 \\
204 \\
217 \\
199 \\
219 \\
\end{array}$ & $\begin{array}{l}65 \\
53 \\
60 \\
62 \\
65 \\
65 \\
56 \\
57 \\
65 \\
61 \\
52 \\
59 \\
50 \\
52 \\
65 \\
62\end{array}$ & $\begin{array}{l}1 \\
1 \\
3 \\
4 \\
1 \\
2 \\
4 \\
4 \\
3\end{array}$ & $\begin{array}{l}1 \\
2 \\
1\end{array}$ & $\begin{array}{r}2 \\
4 \\
1 \\
3 \\
8 \\
1 \\
7 \\
12 \\
2 \\
3 \\
2 \\
5 \\
3 \\
2 \\
3 \\
\end{array}$ & $\begin{array}{l}17 \\
34 \\
27 \\
24 \\
26 \\
29 \\
22 \\
27 \\
11 \\
22 \\
32 \\
21 \\
28 \\
22 \\
14 \\
14 \\
\end{array}$ & 1 & 1 & $\begin{array}{l}1 \\
1\end{array}$ & $\begin{array}{l}1 \\
1 \\
1 \\
1 \\
1 \\
2 \\
3 \\
1 \\
1 \\
1\end{array}$ & $\begin{array}{l}1 \\
1 \\
3\end{array}$ & & & $\begin{array}{l}2 \\
1 \\
2 \\
1 \\
1 \\
2 \\
2 \\
2\end{array}$ & 1 & $\begin{array}{r}4 \\
4 \\
11 \\
4 \\
2 \\
3 \\
2 \\
3 \\
8 \\
3\end{array}$ & $\begin{array}{l}1 \\
1 \\
1 \\
1\end{array}$ & $\begin{array}{l}2 \\
5 \\
1 \\
1 \\
2 \\
3 \\
1\end{array}$ & $\begin{array}{l}1 \\
1\end{array}$ & $\begin{array}{r}2 \\
10 \\
10 \\
12 \\
8 \\
2 \\
4 \\
1 \\
4 \\
2 \\
4 \\
2 \\
4 \\
12 \\
4 \\
1\end{array}$ & $\begin{array}{l}1 \\
2 \\
3\end{array}$ & & & , \\
\hline $\begin{array}{c}\text { lower } \\
\text { Miocenene }\end{array}$ & $\begin{array}{l}35, \mathrm{CC} \\
36-1 \\
36-2 \\
36-3 \\
36-4 \\
36-5 \\
36-6 \\
36, \mathrm{CC} \\
37-1 \\
37-2 \\
37-3 \\
37-4 \\
37-5 \\
37-6 \\
37, \mathrm{CC} \\
38-1 \\
38-2 \\
38-3 \\
38-4 \\
38-5 \\
38-6 \\
38, \mathrm{CC} \\
39-1 \\
39-2 \\
39-3 \\
39-4 \\
39, \mathrm{CC} \\
40-1 \\
40-2 \\
40-4 . \\
40, \mathrm{CC} \cdot \\
41 .-4 \\
41-6 \\
41, \mathrm{CC} \\
42, \mathrm{CC} \\
4\end{array}$ & $\begin{array}{l}328.71 \\
329.70 \\
331.20 \\
332.70 \\
334.20 \\
335.70 \\
337.20 \\
337.62 \\
339.30 \\
340.80 \\
342.30 \\
343.80 \\
345.30 \\
346.80 \\
348.17 \\
348.90 \\
350.50 \\
351.90 \\
3534.90 \\
356.90 \\
358.10 \\
358.50 \\
360.00 \\
361.50 \\
363.00 \\
334.34 \\
368.95 \\
369.20 \\
372.68 \\
376.22 \\
382.55 \\
386.10 \\
386.90 \\
394.24 \\
\end{array}$ & $\begin{array}{l}15.9 \\
16.0 \\
16.1 \\
16.2 \\
16.4 \\
16.6 \\
16.7 \\
16.8 \\
16.9 \\
17.0 \\
17.1 \\
17.4 \\
17.5 \\
17.7 \\
17.9 \\
18.0 \\
18.2 \\
18.3 \\
18.4 \\
18.6 \\
18.7 \\
18.8 \\
18.9 \\
19.0 \\
19.1 \\
19.2 \\
19.4 \\
19.6 \\
19.7 \\
19.8 \\
20.1 \\
20.6 \\
20.8 \\
20.9 \\
22.0\end{array}$ & $\begin{array}{l}204 \\
208 \\
210 \\
253 \\
213 \\
225 \\
213 \\
193 \\
208 \\
225 \\
201 \\
245 \\
265 \\
240 \\
225 \\
250 \\
209 \\
211 \\
211 \\
213 \\
219 \\
192 \\
202 \\
212 \\
218 \\
213 \\
190 \\
220 \\
203 \\
176 \\
196 \\
220 \\
203 \\
211 \\
198\end{array}$ & $\begin{array}{l}55 \\
55 \\
47 \\
64 \\
41 \\
52 \\
64 \\
63 \\
60 \\
60 \\
37 \\
27 \\
12 \\
25 \\
16 \\
29 \\
24 \\
41 \\
44 \\
47 \\
47 \\
51 \\
53 \\
58 \\
54 \\
47 \\
38 \\
71 \\
55 \\
54 \\
44 \\
59 \\
55 \\
62 \\
66 \\
41\end{array}$ & $\begin{array}{l}3 \\
2 \\
6 \\
9 \\
2 \\
1 \\
6 \\
? \\
5 \\
5\end{array}$ & & $\begin{array}{r}1 \\
2 \\
3 \\
3 \\
2 \\
2 \\
2 \\
2 \\
2 \\
1 \\
4 \\
2 \\
7 \\
13 \\
3 \\
4 \\
2 \\
2 \\
1 \\
\end{array}$ & 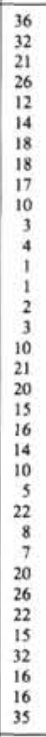 & 1 & & $\begin{array}{l}1 \\
3 \\
1\end{array}$ & $\begin{array}{l}2 \\
1 \\
3 \\
1 \\
1 \\
5\end{array}$ & & & i & $\begin{array}{l}1 \\
2 \\
1 \\
\\
3 \\
1 \\
4 \\
2 \\
1 \\
1\end{array}$ & $\begin{array}{l}3 \\
1 \\
3 \\
5 \\
6 \\
4 \\
1\end{array}$ & $\begin{array}{r}2 \\
2 \\
5 \\
1 \\
4 \\
1 \\
1 \\
10 \\
5 \\
\end{array}$ & $\begin{array}{l}1 \\
1 \\
2\end{array}$ & $\begin{array}{l}1 \\
2 \\
1 \\
3 \\
2 \\
2 \\
1\end{array}$ & 2 & $\begin{array}{l}3 \\
2 \\
2 \\
1 \\
3 \\
5 \\
2 \\
2 \\
5 \\
1\end{array}$ & 1 & 2 & $\begin{array}{r}1 \\
1 \\
3 \\
3 \\
2 \\
2 \\
1 \\
1 \\
2 \\
3\end{array}$ & ? \\
\hline Olizocene & $\begin{array}{l}43, \mathrm{CC} \\
44, \mathrm{CC} \\
46, \mathrm{CC} \\
48, \mathrm{CC}\end{array}$ & $\begin{array}{l}403.98 \\
411.62 \\
431.05 \\
454.10\end{array}$ & $\begin{array}{l}22.4 \\
22.8 \\
24.6 \\
27.0\end{array}$ & $\begin{array}{l}225 \\
2204 \\
228 \\
231\end{array}$ & $\begin{array}{l}54 \\
46 \\
48 \\
65\end{array}$ & $\frac{5}{2}$ & & $\begin{array}{l}1 \\
2 \\
6\end{array}$ & $\begin{array}{l}24 \\
25 \\
20 \\
21\end{array}$ & & 3 & & $\begin{array}{l}5 \\
3 \\
3\end{array}$ & & & & $\begin{array}{l}3 \\
6 \\
5\end{array}$ & $\begin{array}{l}1 \\
5 \\
2\end{array}$ & $\begin{array}{l}5 \\
6 \\
3 \\
7\end{array}$ & 1 & 2 & & $\begin{array}{l}3 \\
3 \\
5 \\
3\end{array}$ & & & $\begin{array}{l}8 \\
1\end{array}$ & \\
\hline
\end{tabular}


Table 1 (continued).

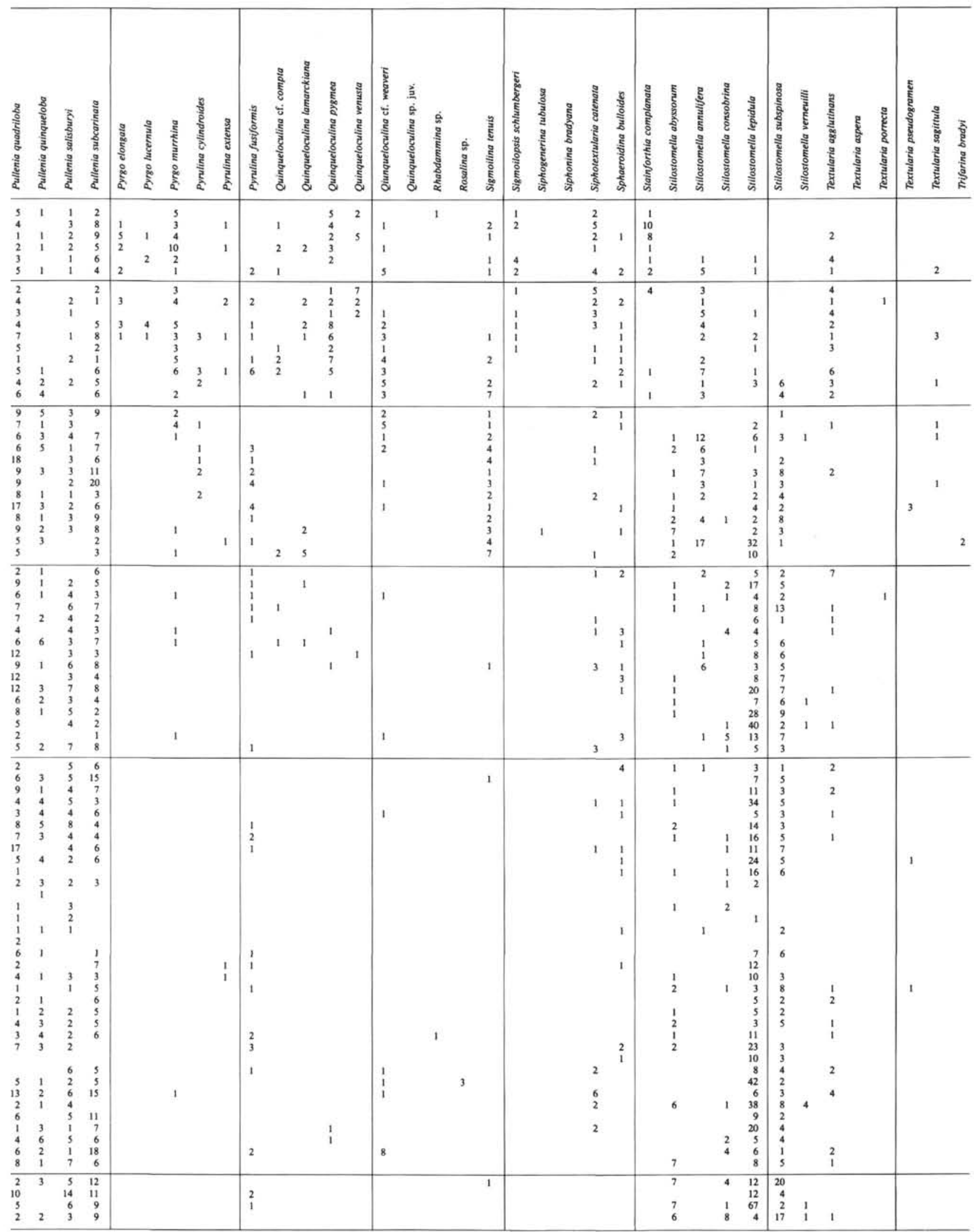


Table 1 (continued).

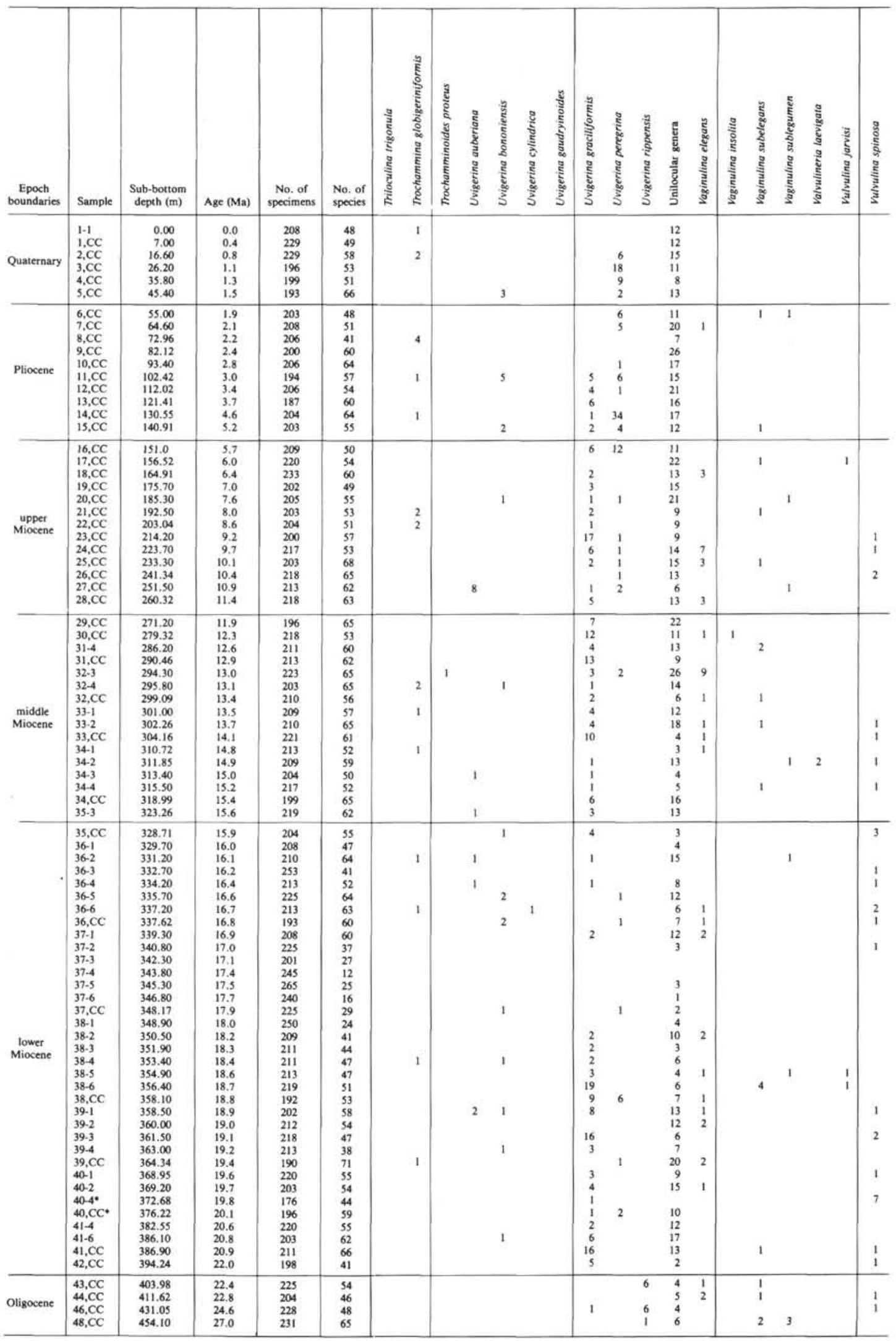


Table 2. Counts of benthic foraminifers in samples from Site 610 .

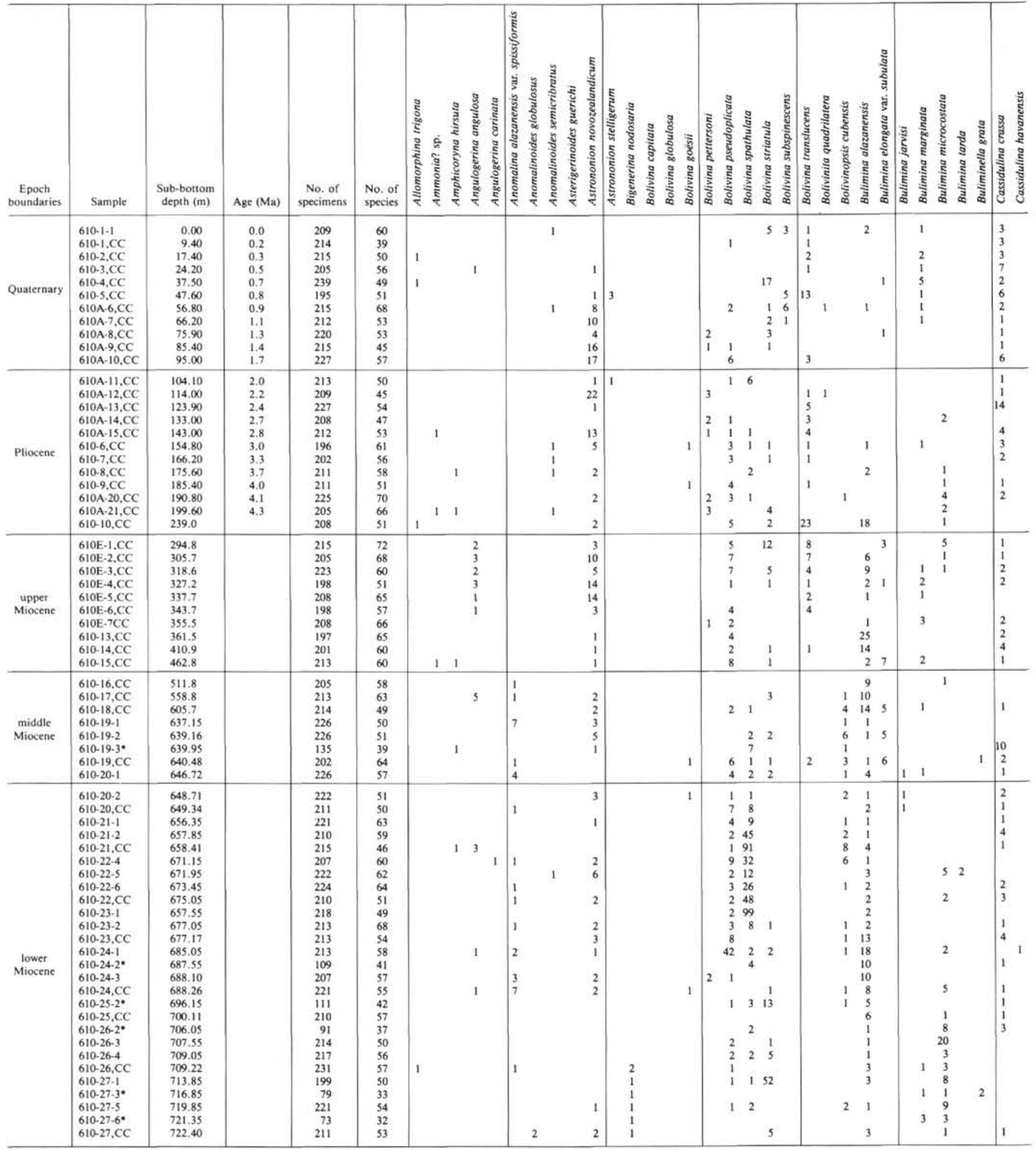

Note: Ages are extrapolated from the paleomagnetic data in Clement and Robinson (this volume). Ages are assigned for the upper part of the section only; in the lower part, the time control is too poor to assign ages. Samples marked with an asterisk contain insufficient specimens and were not used for analysis. 
Table 2 (continued).

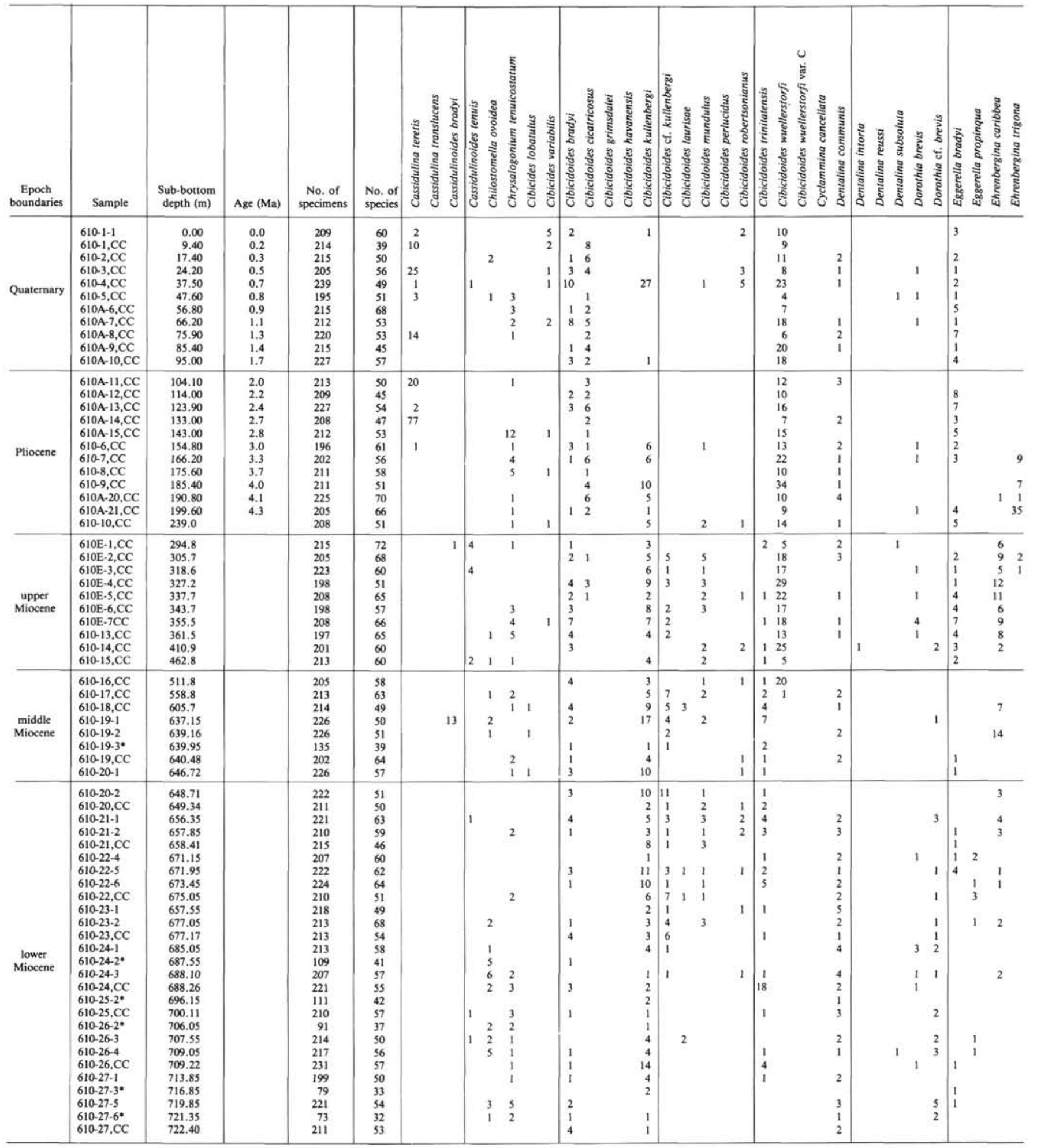


Table 2 (continued).

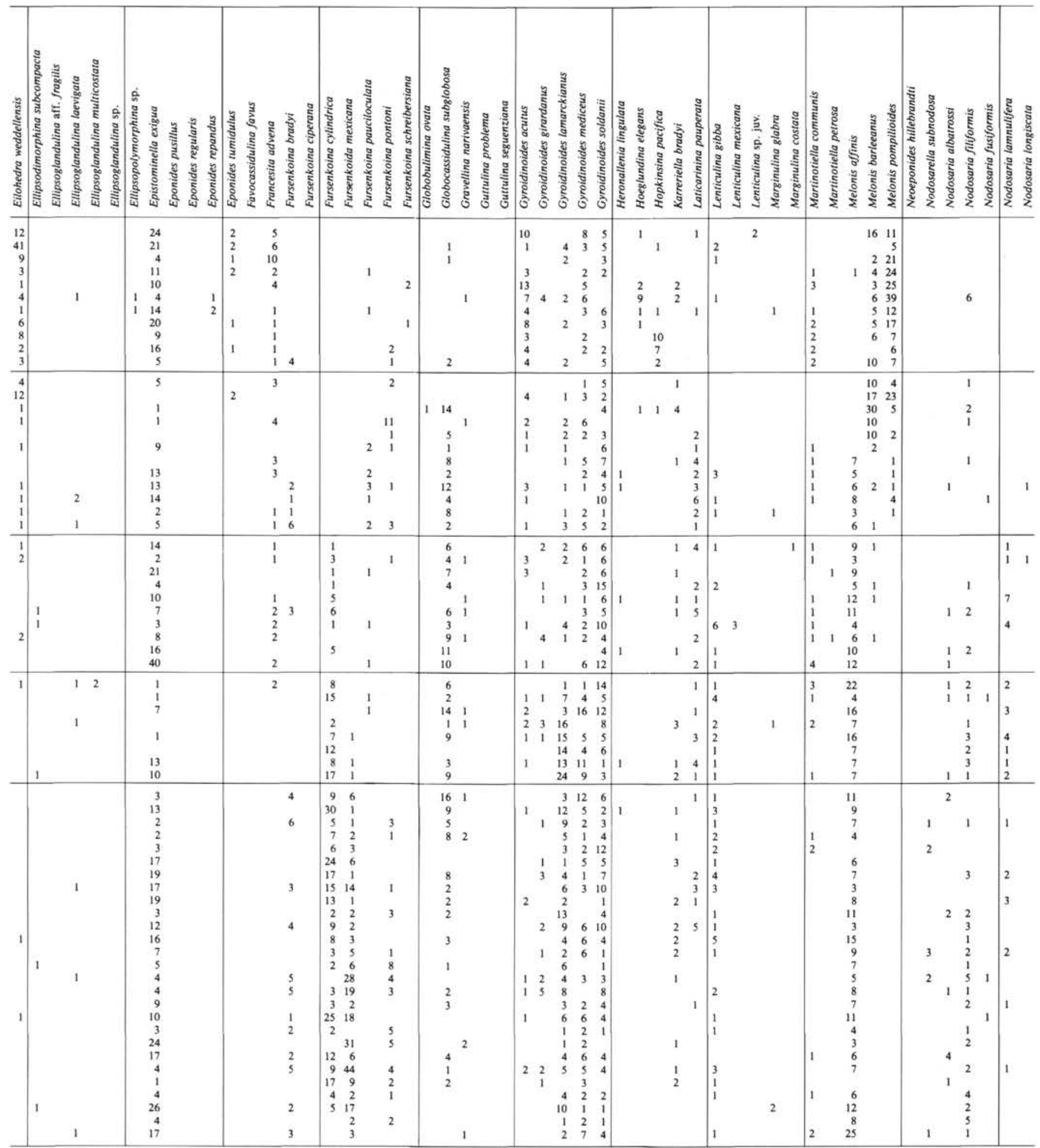


Table 2 (continued).

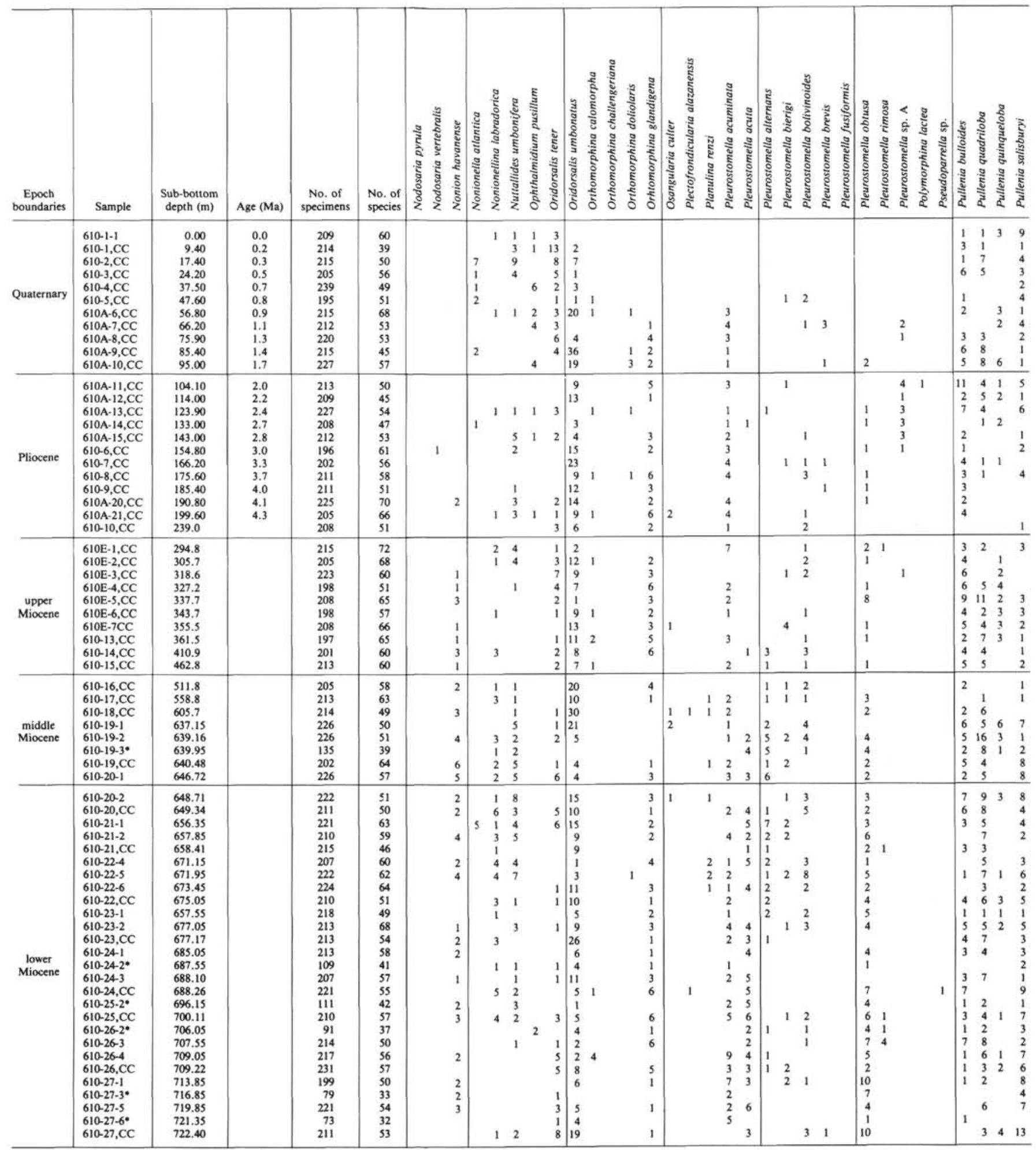


Table 2 (continued).

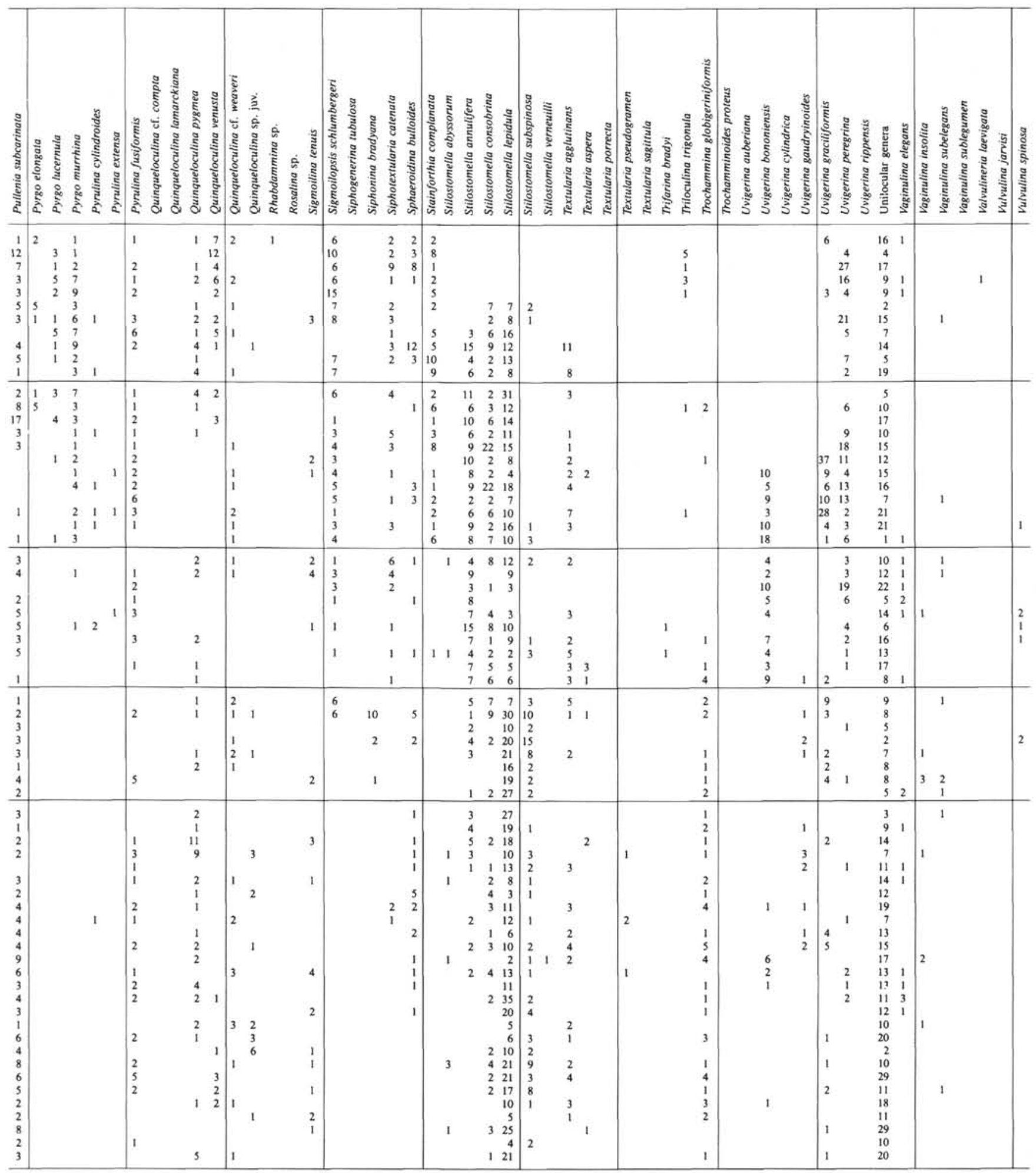




\section{APPENDIX B \\ Taxonomy}

Allomorphina trigona Reuss, 1850, Denkschr., K. Akad. Wiss. Wien, Math. Naturw. Kl., Vol. 1, p. 380.

Ammonia ? sp.: see Thomas, 1985, Init. Repts. DSDP, Vol. 85: pp. 655-694 for a discussion.

Amphicoryna hirsuta (d'Orbigny). Nodosaria hirsuta d'Orbigny, 1826. Ann. Sci. Nat., Ser. 1, Vol. 7, p. 87, no. 7.

Angulogerina angulosa (Williamson). Uvigerina angulosa Williamson, 1858, Recent Foraminifera of Great Britain, p. 67, pl. 1, fig. 140.

Angulogerina carinata Cushman, 1927, Bull Univ. California, Techn. Ser., Vol. 1. p. 159, pl. 4, fig. 3.

Anomalina alazanensis var. spissiformis Cushman and Stainforth, 1945, Spec. Publ. Cushman Lab. Foram. Res., Vol. 14, p. 77, pl. 14, fig. 5.

Anomalinoides globulosus (Chapman and Parr). Anomalina globulosa Chapman and Parr, 1937, Rep. Australasian Antarctic Exped., C, Vol. 1, p. 119, pl. 9, fig. 27.

Anomalinoides semicribratus (Beckmann). Anomalina pompilioides Galloway and Heminway var. semicribrata Beckmann, 1953, Eclogae Geol. Helv., Vol. 10, pp. 400-401, pl. 27, fig. 3, text figs. 24, 25.

Asterigerinoides guerichi (Franke). Discorbina guerichi Franke, 1912, Verein. Preuss. Rheinlande Westfalens, Verhand., Vol. 69, pp. 271273 , pl. 3, figs. 1-3.

Astrononion novozealandicum Cushman and Edwards, 1937, Contrib. Cushman Lab. Foram. Res., Vol. 13, pl. 3, fig. 18.

Astrononion stelligerum (d'Orbigny). Nonionina stelligera d'Orbigny, 1839, Hist. Nat. Iles Canaries, Vol. 2, Pt. 2, Foraminiferes, p. 128, pl. 3 , figs. $1,2$.

Bigenerina nodosaria d'Orbigny, 1826, Ann. Sci. Nat., Ser. 1, Vol. 7, p. 261 , pl. 11, figs. 9-12.

Bolivina capitata Cushman, 1933, Contrib. Cushman Lab. Foram. Res., Vol. 9, Pt. 4, p. 80, pl. 8, figs. 12a, b.

Bolivina goesii Cushman, 1922, Bull. U.S. Nat. Mus., Vol. 104, Pt. 3 , p. 34 , pl. 6 , fig. 5 .

Bolivina globulosa Cushman, 1933, Contrib. Cushman Lab. Foram. Res., Vol. 9, Pt. 4, p. 80, pl. 8, fig. 9.

Bolivina pettersoni Phleger, Parker, and Peirson, 1953, Swedish Deep Sea Exped. 1947-1948, Vol. 7, No. 1, p. 36, pl. 7, figs. 15-17.

Bolivina pseudoplicata Heron-Allen and Earland, 1930, J. R. Microsc. Soc., Ser. 3, Vol. 50 , p. 81 , pl. 3 , figs. $38-40$.

Bolivina spathulata (Williamson). Textularia variabilis var. spathulata Williamson, 1858, Recent Foraminifera of Great Britain, p. 76, pl. 6 , figs. 164,165 .

Bolivina striatula Cushman, 1922, Carnegie Inst. Washington Publ. 311 , p. 27 , pl. 3, fig. 10 . See Thomas, 1985, Init. Repts. DSDP, 85 , pp. 655-694 for a discussion.

Bolivina subspinescens Cushman, 1922, Bull. U.S. Nat. Mus., Vol. 104, Pt. 3, p. 48 , pl. 7 , fig. 5 .

Bolivina translucens Phleger and Parker, 1951, Mem. Geol. Soc. Am., Vol. 46, Pt. 2, p. 15, pl. 7, figs. 13, 14.

Bolivinita quadrilatera (Schwager). Textilaria quadrilatera Schwager, 1866. Novara Exped., Geol. Theil., Vol. 2, p. 253, pl. 7, fig. 103.

Bolivinopsis cubensis (Cushman and Bermudez). Spiroplectoides cubensis Cushman and Bermudez, 1937, Contrib. Cushman Lab. Foram. Res., Vol. 13, Pt. 1, pl. 1, figs. 44, 45.

Bulimina alazanensis Cushman, 1927, J. Paleontol., Vol. 1, p. 161, pl. 25 , fig. 4 .

Bulimina elongata var. subulata Cushman and Parker, 1937, Contrib. Cushman Lab. Foram. Res., Vol. 13, Pt. 2, p. 51, pl. 7, figs. 6-7.

Bulimina jarvisi Cushman and Parker, 1936, Contrib. Cushman Lab. Foram. Res., Vol. 12, p. 39, pl. 7, fig. 1.

Bulimina marginata d'Orbigny, 1826, Ann. Sci. Nat., Ser. 1, Vol. 7, p. 269 , pl. 12, figs. 10-12.

Bulimina microcostata Cushman and Parker, 1936, Contrib. Cushman Lab. Foram. Res., Vol. 12, p. 39, pl. 7, figs. 2a-c.

Bulimina tarda Parker and Bermudez, 1937, J. Paleont., Vol. 11, p. 514 , pl. 58 , figs. $6 \mathrm{a}-\mathrm{c}$.

Buliminella grata Parker and Bermudez, 1937, J. Paleont., Vol. 11, p. 515 , pl. 59 , figs. $6 \mathrm{a}-\mathrm{c}$.

Cassidulina crassa d'Orbigny, 1846, Foraminifères fossiles du Bassin Tertiaire de Vienne, pp. 121-213, pl. 21, figs. 42, 43.
Cassidulina havanensis Cushman and Bermudez, 1936, Contrib. Cushman Lab. Foram. Res., Vol. 12, p. 36, pl. 6, fig. 11.

Cassidulina teretis Tappan, 1951, Contrib. Cushman Found. Foram. Res., Vol. 2, Pt. 1, p. 7, pl. 1, fig. 30.

Cassidulina translucens Cushman and Hughes, 1925, Contrib. Cushman Lab. Foram. Res., Vol. 1, Pt. 1, p. 15, pl. 2, figs. 5a-c.

Cassidulinoides bradyi (Norman). Cassidulina bradyi Norman, 1881, Q. J. Microsc. Sci., New Ser., Vol. 21, p. 59.

Cassidulinoides tenuis Phleger and Parker, 1951, Mem. Geol. Soc. Am., Vol. 46, Pt. 2, p. 27, pl. 14, figs. 14-17.

Chilostomella ovoidea Reuss, 1850, Denkschr. K. Akad. Wiss. Math. Naturw. Kl., Vol. 1, p. 380, pl. 48, fig. 12.

Chrysalogonium tenuicostatum Cushman and Bermudez, 1936, Contrib. Cushman Lab. Foram. Res., Vol. 12, Pt. 2, pp. 27-28, pl. 5, figs. 3-5.

Cibicides lobatulus (Walker and Jacob). Nautilus lobatulus Walker and Jacob, 1798, Adam's Essays on the Microscope, Ed. 2, p. 642, pl. 14 , fig. 36 .

Cibicides variabilis (d'Orbigny). Truncatulina variabilis d'Orbigny, 1826, Ann. Sci. Nat. Ser. I, Vol. 7, p. 279.

Cibicidoides bradyi (Trauth). Truncatulina bradyi Trauth, 1884, Denkschr. K. Akad. Wiss. Wien, Naturw. Kl., Vol. 95, p. 235, pl. 4, figs. 7-9.

Cibicidoides cicatricosus (Schwager). Amonalina cicatricosa Schwager, 1866, Novara Exped., Geol. Theil., Vol. 2, p. 260, pl. 7, fig. 108. Not the same as C. cicatricosus in Resig, 1981, Mem. Geol. Soc. $A m$., Vol. 154, pl. 8 , figs. 13, 14; these specimens have a more acute periphery.

Cibicidoides grimsdalei (Nuttall). Cibicides grimsdalei Nuttall, 1930, J. Paleontol., Vol. 4, p. 291, pl. 25, figs. 7, 8, 11.

Cibicidoides havanensis (Cushman and Bermudez). Cibicides havanensis Cushman and Bermudez, 1937, Contrib. Cushman Lab. Foram. Res., Vol. 13, Pt. 1, p. 28, pl. 3, figs. 1-3.

Cibicidoides kullenbergi (Phleger, Parker and Peirson). Cibicides kullenbergi Phleger, Parker, and Peirson, 1953, Rep. Swedish Deep Sea Exped. 1947-1948, Vol. 7, p. 49, pl. 11, figs. 7, 8. For a discussion see Thomas, 1985, Init. Repts. DSDP, Vol. 85, pp. 655-694. and see under $C$. mundulus.

Cibicidoides ef. kullenbergi. This taxon resembles $C$. kullenbergi in wall structure and chamber arrangement but is smaller, more compressed, and had less pronounced sutures; may be a juvenile form.

Cibicidoides laurisae (Mallory). Cibicides laurisae Mallory, 1959, Lower Tertiary Biostratigraphy of the California Coast Ranges, Am. Assoc. Pet. Geol., Tulsa, Okla., p. 267, pl. 24, figs. 8a-c.

Cibicidoides mundulus (Brady, Parker, and Jones). Truncatulina mundula Brady, Parker, and Jones, 1888, Trans. Zool. Soc. London, Vol. 12 , p. 228 , pl. 45 , fig. 25 . The species was emended by Loeblich and Tappan, 1955, in Smithsonian Inst., Misc. Coll., Washington, D.C., Vol. 128, No. 5 (Publ. 4214), p. 25, pl. 4, fig. 4; it resembles $C$. kullenbergi closely, and the two taxa may in reality be one species. According to the type figures of the two species (op. cit.), however, the ventral sutures of $C$. mundulus are radial and almost straight, whereas they are strongly curved and approximate the periphery tangentially in $C$. kullenbergi.

Cibicidoides perlucidus (Nuttall). Cibicides perlucida Nuttall, 1932, J. Paleontol., Vol. 6, p. 33, pl. 8, figs. 10-12.

Cibicidoides robertsonianus (Brady). Truncatulina robertsoniana Brady, 1881, Q. J. Microsc. Sci., New Ser., Vol. 21, p. 65.

Cibicidoides trinitatensis (Nuttall). Truncatulina trinitatensis Nuttall, 1928, Q. J. Geol. Soc. London, Vol. 84, p. 97, pl. 7, figs. 3, 5, 6. Note that this species is the same as $C$. trincherasensis Beckmann, not Bermudez, Eclogae Geol. Helv., 1953, Vol. 46, p. 656, pl. 18, figs, 4-6.

Cibicidoides wuellerstorfi (Schwager). Anomalina wuellerstorfi Schwager, 1866, Novara Exped., Geol. Theil., Vol. 2, p. 258, pl. 7, figs. 105-107.

Cibicidoides wuellerstorfi var. C: this taxon resembles $C$. wuellerstorfi in overall shape and chamber arrangement, but the evolute side does not have limbate sutures. On the involute side the sutures are less glassy and thickened.

Cyclammina cancellata Brady, 1876, in: Norman, Proc. Roy, Soc. London, Vol. 25 , p. 214.

Dentalina communis d'Orbigny. Nodosaria (Dentalina) communis d’Orbigny, 1826, Ann. Sci. Nat., Ser. 1, Vol. 7, p. 254. 
Dentalina intorta (Dervieux). Nodosaria intorta Dervieux, 1893-1894, Boll. Soc. Geol. Ital., Vol. 12, p. 610.

Dentalina reussi Neugeboren, 1856, Denkschr. K. Akad. Wiss., Math. Naturw, Kl., Vol. 12, Pt. 2, p. 85, pl. 3, 6-7.

Dentalina subsoluta (Cushman). Nodosaria subsoluta Cushman, 1923, Bull. U.S. Nat. Mus., Vol. 104, Pt. 4, p. 74, pl. 13, fig. 1.

Dorothia brevis Cushman and Stainforth, 1945, Spec. Publ. Cushman Lab. Foram. Res., Vol. 14, p. 18, pl. 2, fig. 5 .

Dorothia cf. brevis: similar to $D$. brevis in wall structure and chamber arrangement, but more rounded in cross section, chambers more bulbous and flattened in the length direction of the test.

Eggerella bradyi (Cushman). Verneuillina bradyi Cushman, 1911, Bull. U.S. Nat. Mus., Vol. 71 , Pt. 2, p. 54 , text figs. 87 a, b.

Eggerella propinqua (Brady). Verneuillina propinqua Brady, 1884, Rep. Voy. Challenger, Zool., Vol. 9, p. 383, pl. 47, figs. 8-12.

Ehrenbergina caribbea Galloway and Heminway, 1941. N. Y. Acad. Scientific Survey Porto Rico and Virgin Islands, Vol. 3, Pt. 4, p. 426 , figs $4 a-d$.

Ehrenbergina trigona Goes. Ehrenbergina serrata var. trigona Goes, 1896, Bull. Harvard College Mus. Comp. Zool., Vol. 29, p. 49, pl. 6 , figs. 184,185 .

Eilohedra weddellensis (Earland). Eponides weddellensis Earland, 1936, Discovery Repts., Vol. 13, p. 57, pl. 1, figs. 65-67. See Thomas, 1985 , Init. Repts. DSDP, Vol. 85 , pp. 655-694.

Ellipsodimorphina subcompacta Liebus, 1922, Lotos (Praga), Vol. 70, p. 57 , pl. 2. fig. 13.

Ellipsoglandulina aff. fragilis Bramlette. Ellipsoglandulina sp. aff. fragilis Bramlette, Beckmann, 1953, Eclogae Geol. Helv., Vol. 46, p. 379 , pl. 28 , fig. 7 .

Ellipsoglandulina laevigata Silvestri, 1900. Mem. R. Accad. Sci. Lett., e Arte degli Zelanti, Cl. Sci., Nuova Serie, Vol. 10, p. 12.

Ellipsoglandulina multicostata Galloway and Morrey, 1929, Bull. Am. Geol., Vol. 15, No. 55, p. 42, pl. 6, fig. 13.

Elliposglandulina sp.: a species with strongly depressed sutures, inflated chambers.

Ellipsopolymorphina sp.: last chambers are more enveloping than in E. fornasinii, first chambers more elongated than in E. schlichtii.

Epistominella exigua (Brady). Pulvinulina exigua Brady, 1884, Rep. Voy. Challenger, Zool., Vol. 9, p. 696, pl. 103, figs. 13a-c, 14a-c.

Eponides pusillus Parr, 1950, BANZ Antarctic Res. Exped., Vol. 5, Pt. 6, p. 360 , pl. 14, figs. 14a-c.

Eponides regularis Phleger and Parker, 1951, Mem. Geol. Soc. Am., Vol. 46, Pt. 2, p. 21, pl. 11, figs. 3a, b, 4a-c.

Eponides repandus (Fichtel and Moll). Nautilus repandus Fichtel and Moll, 1798, Testacea Microscopica, p. 35, pl. 3, figs. a-d.

Favocassidulina favus (Brady). Pulvinulina fava Brady, 1877, Suppl. Notes Foram. Chalk, New Britain Group, Geol. Mag. London, New Ser., Vol. 4, No. 12, p. 535.

Francesita advena (Cushman). Vaginulina(?) advena Cushman, 1922, Bull. U.S. Nat. Mus., Vol. 104, Pt. 3, p. 120, pl. 25, figs. 1-3.

Fursenkoina bradyi (Cushman). Vaginulina bradyi Cushman, 1922, Bull. U.S. Nat. Mus., Vol. 104, Pt. 3, p. 115, pl. 24, fig. 1.

Fursenkoina ciperana (Cushman and Stainforth). Virgulina ciperana Cushman and Stainforth, 1945, Contrib. Cushman Lab. Foram. Res., Vol. 14, p. 46, pl. 7, fig. 10.

Fursenkoina cylindrica (Cushman and Bermudez). Virgulina cylindrica Cushman and Bermudez, 1936, Contrib. Cushman Lab. Foram. Res., Vol. 12, Pt. 2, pp. 30-31, pl. 5, figs. 15a-c.

Fursenkoina mexicana (Cushman). Virgulina mexicana Cushman, 1922, Bull. U.S. Nat. Mus., Vol. 104, Pt. 3, p. 120, pl. 23, fig. 8.

Fursenkoina pauciloculata (Brady). Virgulina pauciloculata Brady, 1884, Rep. Voy. Challenger. Zool., Vol. 9, p. 414, pl. 52, figs. 4, 5.

Fursenkoina pontoni (Cushman). Virgulina pontoni Cushman, 1932, Contrib. Cushman Lab. Foram. Res., Vol 8, Pt. 1, No. 118, p. 17, pl. 3 , fig. 7.

Fursenkoina schreibersiana Czjzek, 1848, Haidinger's Naturw. Abh., Wien, Vol. 2, Pt. 1, p. 147, pl. 13, figs. 18-21.

Globobulimina ovata (d'Orbigny). Bulimina ovata d'Orbigny, 1846, Foraminifères fossiles du Bassin Tertiaire de Vienne, p. 185, pl. 11, figs. 13,14

Globocassidulina subglobosa (Brady). Cassidulina subglobosa Brady, 1884, Rep. Voy. Challenger, Zool., Vol. 9, p. 430, pl. 54, figs. 17a-c.

Gravellina narivaensis Brönnimann, 1953, Contrib. Cushman Found. Foram, Res., Vol. 4, Pt. 1, p. 88, text fig. 1, pl. 15, fig. 8 .
Guttulina problema d'Orbigny, 1826. Ann. Sci. Nat. Ser. 1, Vol. 6, p. 266 , no. 14 .

Guttulina seguenziana (Brady). Polymorphina seguenziana Brady, 1884, Rep. Voy. Challenger, Zool., Vol. 9, p. 567, pl. 72, figs. 16, 17.

Gyroidinoides acutus (Boomgaart). Gyroidina neosoldanii Brotzen var. acuta Boomgaart, 1949, Univ. Utrecht doctoral dissert., p. 124, pl. 9, figs. 1a-c.

Gyroidinoides girardanus (Reuss). Rotalina girardana Reuss, 1851, Zeitschr. Deutsche Geol. Ges., Vol. 3, p. 73, pl. 5, fig. 34.

Gyroidinoides lamarckianus (d'Orbigny). Rotalina lamarckiana d'Orbigny, 1839, Hist. Nat. Iles Canaries, Foraminifères, Vol. 2, Pt. 2, p. 131, pl. 2, figs. 13-15.

Gyroidinoides mediceus (Emiliani), Gyroidina medicea Emiliani, 1954, Palaeontographica Italiana, Vol. 48, p. 136, pl. 24, fig. 6 .

Gyroidinoides soldanii (d'Orbigny). Gyroidina soldanii d'Orbigny, 1826, Ann. Sci. Nat., Ser. 1, Vol. 7, p. 298, no. 5, model no. 36.

Heronallenia lingulata (Burrows and Holland). Discorbina lingulata Burrows and Holland, 1896, in Jones, Foram. Crag, Pt. 3, p. 297, pl. 7, fig. 33.

Hoeglundina elegans (d'Orbigny). Rotalia (Turbinulina) elegans d'Orbigny, 1826, Ann. Sci. Nat., Ser. 1, Vol. 7, p. 276, models no. 34.

Hopkinsina pacifica Cushman, 1933, Contrib. Cushman Lab. Foram. Res., Vol. 9, Pt. 4, no. 137, p. 86, pl. 8, fig. 16.

Karreriella bradyi (Cushman). Gaudryina bradyi: Cushman, 1911, Bull. U.S Nat. Mus., Vol. 71, Pt. 2, p. 67, fig. 107.

Laticarinina paupertata (Parker and Jones). Pulvinulina repanda var. menardii subvar. pauperata Parker and Jones, 1865, Philos. Trans. $R$. Soc. London, Vol. 155, p. 395, pl. 16, figs. 50-51.

Lenticulina gibba (d'Orbigny). Cristellaria gibba d'Orbigny, 1826, Ann. Sci. Nat., Ser. 1, Vol. 7, p. 292, no. 7.

Lenticulina mexicana (Cushman). Cristellaria mexicana Cushman, 1925, Bull. Am. Assoc. Pet. Geol., Vol. 9, p. 299, pl. 7, figs. 1, 2.

Lenticulina sp. juv.: includes all Lenticulina specimens with 2-3 chambers only that cannot be assigned to a species.

Marginulina costata (Montagu). Nautilus costatus Montagu, 1803, Testacea Brittanica, p. 199, pl. 14, fig. 5.

Marginulina glabra var. obesa Cushman. Marginulina glabra d'Orbigny var. obesa Cushman, 1923, Bull. U.S. Nat. Mus., Vol. 104, Pt. 4, p. 128, pl. 37, fig. 1.

Martinotiella communis (d'Orbigny). Clavulina communis d'Orbigny, 1826, Ann. Sci. Nat., Ser. I, Vol. 7, p. 268, no. 4.

Martinotiella petrosa (Cushman and Bermudez). Listerella petrosa Cushman and Bermudez, 1937, Contrib. Cushman Lab. Foram. Res., Vol. 13, p. 5, Pl. 1, figs. 24-26.

Melonis affinis (Reuss). Nonionina affinis Reuss, 1851, Zeitschr. Deutsche Geol. Ges., Vol. 3, p. 72, pl. 5, fig. 32. There is considerable confusion in the literature regarding this species, which closely resembles $M$. barleeanus. I use " $M$. barleeanus-group" for the two species together, and give the name $M$. affinis to specimens that have a smooth wall with less obvious large pores when viewed under the light microscope. These smoother specimens were not found in the samples from the equatorial Pacific (Thomas, 1985, Init. Repts. DSDP, Vol. 85, pp. 655-694).

Melonis barleeanus (Williamson). Nonionina barleeana Williamson, 1858. Recent Foraminifera of Great Britain p. 32, pl. 3, fig. 68-69.

Melonis pompilioides (Fichtel and Moll). Nautilus pompilioides Fichtel and Moll, 1798, Testacea Microscopica p. 31, pl. 2, figs. a-c.

Neoeponides hillebrandti Fisher, 1969, Palaeontology, Vol. 12, Pt. 2, p. 197.

Nodosarella subnodosa (Guppy). Ellipsoidina subnodosa Guppy, 1894, Proc. Zool. Soc. London, p. 650, pl. 61, fig. 12.

Nodosaria albatrossi Cushman. Nodosaria vertebralis var. albatrossi Cushman, 1924, Bull. U.S. Nat. Mus., Vol. 104, Pt. 4, p. 87, pl. 15 , fig. 1.

Nodosaria filiformis d'Orbigny, 1826, Ann. Sci. Nat. Ser. 1, Vol. 7, p. 254 , no. 14

Nodosaria fusiformis Silvestri, 1872, Atti Accad. Gioenia Sci. Nat. Catania, Ser. 3, Vol. 7, p. 99, fig. 34

Nodosaria lamnulifera Boomgaart, 1950, Contrib. Cushman Lab. Foram. Res., Vol. 1, p. 42.

Nodosaria longiscata d'Orbigny, 1846. Foraminifères fossiles du Bassin Tertiaire de Vienne, p. 32, pl. 1, figs. 10-12.

Nodosaria pyrula d'Orbigny, 1826, Ann. Sci. Nat. Ser. 1, Vol. 7, p. 253, no. 13 
Nodosaria vertebralis (Batsch). Nautilus (Orthoceras) vertebralis Batsch, 1791, Conchyl. Seesandes, p. 3, nr. 6, pl. 2, fig. 6.

Nonion havanense Cushman and Bermudez, 1937, Contrib. Cushman Lab. Foram. Res., Vol. 13, p. 19, pl. 2, figs. 13, 14.

Nonionella atlantica Cushman, 1947, Contrib. Cushman Lab. Foram. Res., Vol. 23, p. 90 , pl. 20, figs. 4,5 .

Nonionella labradorica (Dawson). Nonionina labradorica Dawson, 1860, Can. Naturalist, Vol. 5, p. 191, fig. 4.

Nuttallides umbonifera (Cushman). Pulvinulinella umbonifera Cushman, 1933, Contrib. Cushman Lab. Foram. Res., Vol. 9, Pt. 4, pl. 9, figs. 9a-c.

Opthalmidium pusillum (Earland). Spiroloculina pusilla Earland, 1934, Discovery Repts., Vol. 10, p. 47, pl. 1, figs. 3, 4

Oridorsalis tener (Brady). Truncatulina tenera Brady, 1884, Rept. Voy. Challenger, Zool., Vol. 9, p. 665, pl. 95, figs. 11a-c.

Oridorsalis umbonatus (Reuss). Rotalina umbonata Reuss, 1851, Zeitschr. Deutsche Geol. Ges., Vol. 3, p. 75, pl. 5, figs. 35a-c.

Orthomorphina calomorpha (Reuss). Nodosaria (Nodosaria) calomorpha Reuss, 1886, Denkschr. K. Akad. Wiss. Wien, Math. Naturw. $K l$., Vol. 25 , p. 129 , pl. 1, figs. $15-19$.

Orthomorphina challengeriana (Thalmann). Nodogenerina challengeriana Thalmann, 1937, Eclogae Geol. Helv., Vol. 30, p. 341.

Orthomorphina doliolaris (Parr). Nodosaria doliolaris Parr, 1950, BANZ Antarctic Res. Exped., Ser. B, Vol. 5, p. 290, pl. 12, fig. 2.

Orthomorphina glandigena (Schwager). Nodosaria glandigena Schwager, 1866, Novara Exped., Geol. Theil., Vol. 2, p. 219, pl. 5, fig. 46.

Osangularia culter (Parker and Jones). Planorbulina culter Parker and Jones, 1865, Philos. Trans. R. Soc. London, Vol. 155, p. 421 , pl. 19 , fig. 1 .

Planulina renzi Cushman and Stainforth, 1945. Spec. Publ. Cushman Lab. Foram. Res., Vol. 14, p. 72, pl. 15, fig. 1; 20, figs. 4, 5.

Plectofrondicularia alazanensis Cushman, 1927, Contrib. Cushman Lab. Foram. Res., Vol. 3, p. 113, pl. 22, fig. 12.

Pleurostomella acuminata Cushman, 1922, Bull. U.S. Nat. Mus., Vol. 104 , Pt. 3, p. 50, pl. 19, fig. 6.

Pleurostomella acuta Hantken, 1875, Mitt. K. Ungar. Geol. Anst., Vol. 4, Pt. 1, p. 44, pl. 13, fig. 18 .

Pleurostomella alternans Schwager, 1866, Novara Exped., Geol. Theil., Vol. 2, p. 238, pl. 6, fig. 79.

Pleurostomella bierigi Palmer and Bermudez, 1936, Mem. Soc. Cubana Hist. Nat., Vol. 10, p. 294, pl. 17, fig. 7, 8.

Pleurostomella bolivinoides Schubert, 1911, Abh. Geol. Reichsanst. Wien, Vol. 20, Pt. 4, p. 57, pl. 4.

Pleurostomella brevis Schwager, 1866, Novara Exped., Geol. Theil., Vol. 2, p. 239, pl. 6, fig. 81 .

Pleurostomella fusiformis Reuss, 1860, Sitzungsber. K. Akad. Wiss. Wien, Math. Naturw. Kl., Vol. 40, p. 205, pl. 8, fig. 1.

Pleurostomella obtusa Berthelin, 1880, Mem. Soc. Geol. France, Ser. 3, Vol. 1, Pt. 5, p. 29, pl. 1, fig. 9.

Pleurostomella rimosa Cushman and Bermudez, 1937, Contrib. Cushman Lab. Foram. Res., Vol. 13, Pt. 1, p. 17, pl. 1, figs. 62, 63.

Polymorphina lactea (Walker and Jacob). Serpula lactea Walker and Jacob, 1798, Adam's Essays on the Microscope, Ed. 2, p. 634 pl. 24 , fig. 4 .

Pseudoparrella sp. This species resembles $P$. peruviana Cushman closely in the shape of the chambers on the evolute side, but it is more flattened and has a broadly rounded periphery. p. garrisoni Lipps has wider chambers and less curved sutures on the evolute side.

Pullenia bulloides (d'Orbigny). Nonionina bulloides d'Orbigny, 1846, Foraminifères fossiles du Bassin Tertiaire de Vienne, p. 107, pl. 5 , figs. $9,10$.

Pullenia quadriloba Reuss. Pullenia compressiuscula var. quadrilobo Reuss, 1867, Denkschr. K. Akad. Wiss. Wien, Math. Naturw. Kl., Ser. B, Vol. 55, pl. 3, fig. 8 .

Pullenia quinqueloba (Reuss). Nonionina quinqueloba Reuss, 1857, Zeitschr. Deutsche Geol. Ges., Vol. 3, p. 47, pl. 5, fig. 31.

Pullenia salisburyi Stewart and Stewart, 1930. J. Paleontol., Vol. 4, p. 72 , pl. 8 , figs. $2 \mathrm{a}$, b.

Pullenia subcarinata (d'Orbigny). Nonionina subcarinata d'Orbigny, 1839, Voy. Amer. Merid., Vol. 5, p. 28, pl. 5, figs. 23, 24.

Pyrgo elongata (d'Orbigny). Biloculina elongata d'Orbigny, 1826, Ann. Sci. Nat. Ser. 1, Vol. 7, p. 298, no, 4

Pyrgo lucernula (Schwager). Biloculina lucernula Schwager, 1866, Novara Exped., Geol. Theil., Vol. 2, p. 202, pl. 4, fig. 14.
Pyrgo murrhina (Schwager). Biloculina murrhina Schwager, 1866, Novara Exped., Geol. Theil., Vol. 2, p. 203, pl. 4, figs 5a-c.

Pyrulina cylindroides (Roemer). Polymorphina cylindroides Roemer 1838, Neues Jb. Min. Geogn. Geol. Petrefaktenkunde, p. 385, pl. 3 , figs $26 a-b$.

Pyrulina extensa (Cushman). Polymorphina extensa Cushman, 1923 Bull. U.S. Nat. Mus., Vol. 104, Pt. 4, p. 156, pl.41, figs. 7, 8.

Pyrulina fusiformis (Roemer). Polymorphina fusiformis Roemer, 1838 , Neues Jb. Min. Geogn. Geol. Petrefaktenkunde, p. 386, pl. 3, figs. 37a-b.

Quinqueloculina compta Cushman, 1947, Contrib. Cushman Lab. Foram. Res., Vol. 23, p. 87, pl. 19, fig. 2.

Quinqueloculina lamarckiana d'Orbigny, 1839, in de la Sagra, Hist. Phys. Pol. Nat. Cuba, p. 189, pl. 11, figs. 14, 15.

Quinqueloculina pygmaea Reuss, 1850, Denkschr. K. Akad. Wiss. Wien, Math. Naturw. Kl., Vol. 1, p. 384, pl. 50, fig. 3.

Quinqueloculina venusta Karrer, 1868, Sitzungsber. K. Akad. Wiss. Wien, Math. Naturw. Kl., Vol. 58, Abt. 1, p. 147, pl. 2, fig. 6.

Quinqueloculina cf. weaveri Rau. Quinqueloculina cf. weaveri Phleger, Parker, and Peirson, 1953, Rep. Swedish Deep Sea Exped., Vol. 7 , p. 28 , pl. 5 , figs. 13,14

Quinqueloculina sp. juv.: all specimens that have less than 6 chambers, and cannot be assigned to a species.

Rhabdammina sp.: found as fragments only; I did not try to assign these to a species.

Sigmoilina tenuis (Czjzek). Quinqueloculina tenuis Czjzek, 1848, Haidinger's Naturw. Abh., Vol. 2, Pt. 1, p. 149, pl. 13, figs. 31-34.

Sigmoilopsis schlumbergeri (Silvestri). Sigmoilina schlumbergeri Silvestri, 1904, Mem. Accad. Pont. Romani Nuovi Lincei, Vol. 22, pp. $267-269$.

Siphonina bradyana Cushman, 1927, Proc. U.S. Nat. Mus., Vol. 72 , no. 2716 , art. 20 , p. 11 , pl. 1 , fig. 4 .

Siphotextularia catenata (Cushman). Textularia catenata Cushman, 1911, Bull. U.S. Nat. Mus., Vol. 71, Pt. 2, p. 23, figs. 39, 40. agree with Corliss, 1979, Micropalentology, Vol. 25 , p. 5 , pl. 1 , figs. 1,2 , that $S$. rolshauseni (Phleger and Parker) is a junior synonym of $S$. catenata.

Sphaeroidina bulloides d'Orbigny, 1826, Ann. Sci. Nat., Ser. 1, Vol. 7 , p. 267 , model No. 65 .

Stainforthia complanata (Egger). Virgulina schreibersiana var. complanata Egger, 1893, Abh. Bayer. Akad. Wiss., Math.-Phys. Naturw. Kl., p. 292, pl. 8, figs 91,92 .

Stilostomella abyssorum (Brady). Nodosaria abyssorum Brady, 1881. Q. J. Microsc. Sci., New Ser., Vol. 21, p 63.

Stilostomella annulifera (Cushman and Bermudez). Ellipsonodosaria annulifera Cushman and Bermudez, 1936, Contrib. Cushman Lab. Foram. Res., Vol. 12, Pt. 2, p. 28, pl. 5, figs. 8, 9.

Stilostomella consobrina (d'Orbigny). Dentalina consobrina d'Orbigny, 1846, Foraminifères fossiles du Bassin Tertiaire de Vienne, p. 46, pl. 2, figs. 1-3. There is considerable confusion in the nomenclature within the genus Stilostomella. I use $S$. consobrina for forms in which the last chambers are elongated, $S$. lepidula for forms with rounded chambers with a ridge or ring of spines along the base of the chambers, and $S$. subspinosa for forms with rounded chambers covered with spines.

Stilostomella lepidula (Schwager), Nodosaria lepidula Schwager, 1866. Novara Exped. Geol. Theil., Vol. 2, pp. 210, 211, pl. 5, figs. 27, 28. S. antillea (Cushman), 1923, Bull. U.S. Nat. Mus., Vol. 104, Pt. 4, p. 91 , fig. 9 is a junior synonym in my opinion.

Stilostomella subspinosa (Cushman). Ellipsonodosaria subspinosa Cushman, 1943, Contrib. Cushman Lab. Foram. Res., Vol. 19. p. 92 , pl. 16 , figs. 16,17 .

Stilostomella verneuilli (d'Orbigny). Dentalina verneuilli d'Orbigny, 1846, Foraminiferes fossiles du Bassin Tertiaire de Vienne, p. 48, pl. 2 , figs. 7,8 .

Textularia agglutinans d'Orbigny, 1839, in de la Sagra, Hist. Phys. Pol. Nat. Cuba, p. 136, p. 1, figs. 17, 18, 32, 34 .

Textularia aspera Brady, 1884, Rep. Voy. Challenger, Zool., Vol. 9, p. 366 , pl. 44 , figs. $9-11$ (not figs. 12,13 ).

Textularia porrecta Brady, Textularia agglutinans var. porrecta Brady, 1884, Rep. Voy. Challenger, Zool., Vol. 9, p. 364, pl. 364, pl. 43, fig. 4 .

Textularia pseudogramen Chapman and Parr, 1937, Sci. Rep. Australasian Antarctic Exped., Vol. 1, p. 153. 
Textularia sagittula Defrance, 1824, in de Blainville, Dict. Sci. Nat., Paris, Vol. 32, p. 177, pl. 13, fig. 5 .

Trifarina bradyi Cushman, 1923, U.S. Nat. Mus., Vol. 104, Pt. 4, p. 99 , pl. 22, figs. 3-9.

Triloculina trigonula (Lamarck). Miliolites trigonula Lamarck, 1804, Ann. Mus. Natl. Hist. Nat. Paris, Pt. 5, p. 351, pl. 17, fig. 4.

Trochammina globigeriniformis (Parker and Jones). Lituola nautiloidea var. globigeriniformis Parker and Jones, 1865, Philos. Trans. $R$. Soc. London, Vol. 155, pl. 17, fig. 96.

Trochamminoides proteus (Karrer). Trochammina proteus Karrer, 1865, Sitzungsber. K. Akad. Wiss, Wien, Math. Naturw. Kl., Vol. 52, Pt. 1, p. 494, fig. 8 (not figs. 1-7).

Unilocular genera: I did not assign specific or generic names to any of the occasionally common unilocular specimens, but I grouped these specimens and counted the number of species to which they belong. This number was used in the calculation of the total number of species per sample.

Uvigerina auberiana d'Orbigny, 1839, in de la Sagra, Hist. Phys. Pol. Nat. Cuba, p. 106, pl. 2, figs. 23, 24

Uvigerina bononiensis Fornasini, 1888. Boll. Soc. Geol. Ital., Vol. 7, Pt. 1, pl. 3, figs. 12, 12a.

Uvigerina cylindrica (d'Orbigny). Clavulina cylindrica d’Orbigny, 1852, Prodr. Paleont. Stratigr., Vol. 3, p. 94.
Uvigerina gaudryinoides Lipparini. Uvigerina tenuistriata var. gaudryinoides Lipparini, 1932, Giornale de Geologia, Bologna, Ser. 2, Vol. 7 , p. 65 , pl. 6 , figs. 7,8 .

Uvigerina graciliformis Papp, 1953. Jahrb. Geol. Bundesanst., Vol. 16 , p. 122 , pl. $5 \mathrm{~A}$, figs. $5-7$.

Uvigerina peregrina Cushman, 1923, Bull. U.S. Nat. Mus., Vol. 104, Pt. 4, p. 166, pl. 42, figs. 7-10.

Uvigerina rippensis Cole, 1927, Bull. Am. Paleontol., Vol. 14, no. 51, p. 11 , pl. 2, fig. 16.

Vaginulina elegans d'Orbigny, 1826, Ann. Sci. Nat. Ser. I, Vol. 7, p. 257 , no. 1 , model no. 54

Vaginulina insolita (Schwager). Cristellaria insolita Schwager, 1866, Novara Exped., Geol. Theil., Vol. 2, p. 242, pl. 6, fig. 85.

Vaginulina subelegans Parr, 1950, BANZ Antarctic Res. Exped., Ser. B, Vol. 5, Pt. 6, p. 326, pl. 11, figs. 20a, b.

Vaginulina sublegumen (Parr). Vaginulinopsis sublegumen Parr, 1950, BANZ Antarctic Res. Exped., Ser. B, Vol. 5, Pt. 6, p. 325, pl. 11, figs, $18 \mathrm{a}, \mathrm{b}$.

Valvulineria laevigata Phleger and Parker, 1951, Mem. Geol. Soc. Am., Vol. 46, Pt. 2, p. 25, pl. 13, figs. 3-9.

Vulvulina jarvisi Cushman, 1932, Contrib. Cushman Lab. Foram. Res., Vol. 8 , p. 84 , pl. 10, fig. 10 .

Vulvulina spinosa Cushman, 1927, Contrib. Cushman Lab. Foram. Res., Vol. 3, Pt. 2, p. 111, pl. 23, fig. 1. 